Atmos. Chem. Phys., 13, 11019-11058, 2013

www.atmos-chem-phys.net/13/11019/2013/

doi:10.5194/acp-13-11019-2013

(c) Author(s) 2013. CC Attribution 3.0 License.

\title{
Emissions of air pollutants and greenhouse gases over Asian regions during 2000-2008: Regional Emission inventory in ASia (REAS) version 2
}

\author{
J. Kurokawa ${ }^{1,2}$, T. Ohara ${ }^{2}$, T. Morikawa ${ }^{3,4}$, S. Hanayama ${ }^{5}$, G. Janssens-Maenhout ${ }^{6}$, T. Fukui ${ }^{7}$, K. Kawashima ${ }^{8}$, and \\ H. Akimoto ${ }^{1}$
}

${ }^{1}$ Asia Center for Air Pollution Research, 1182 Sowa, Nishi-ku, Niigata, Niigata, 950-2144, Japan

${ }^{2}$ National Institute for Environmental Studies, 16-2 Onogawa, Tsukuba, Ibaraki, 305-8506, Japan

${ }^{3}$ Japan Automobile Research Institute, 2530, Karima, Tsukuba, Ibaraki, 305-0822, Japan

${ }^{4}$ Japan Petroleum Energy Center, 4-3-9 Toranomon, Minato-ku, Tokyo, 105-0001, Japan

${ }^{5}$ Ocean Policy Research Foundation, 3-4-10 Toranomon, Minato-ku, Tokyo, 105-0001, Japan

${ }^{6}$ European Commission, Joint Research Center, Via Enrico Fermi 2749, 21027, Ispra, Varese, Italy

${ }^{7}$ The Institute of Behavioral Sciences, 2-9 Ichigayahonmura-cho, Shinjuku-ku, Tokyo, 162-0845, Japan

${ }^{8}$ Mitsubishi UFJ Research and Consulting Co., Ltd., 5-11-2 Toranomon, Minato-ku, Tokyo, 105-8501, Japan

Correspondence to: J. Kurokawa (kurokawa@acap.asia)

Received: 25 March 2013 - Published in Atmos. Chem. Phys. Discuss.: 17 April 2013

Revised: 13 September 2013 - Accepted: 9 October 2013 - Published: 13 November 2013

\begin{abstract}
We have updated the Regional Emission inventory in ASia (REAS) as version 2.1. REAS 2.1 includes most major air pollutants and greenhouse gases from each year during 2000 and 2008 and following areas of Asia: East, Southeast, South, and Central Asia and the Asian part of Russia. Emissions are estimated for each country and region using updated activity data and parameters. Monthly gridded data with a $0.25^{\circ} \times 0.25^{\circ}$ resolution are also provided. Asian emissions for each species in 2008 are as follows (with their growth rate from 2000 to 2008): $56.9 \mathrm{Tg}(+34 \%)$ for $\mathrm{SO}_{2}, 53.9 \mathrm{Tg}(+54 \%)$ for $\mathrm{NO}_{\mathrm{x}}, 359.5 \mathrm{Tg}(+34 \%)$ for $\mathrm{CO}, 68.5 \mathrm{Tg}(+46 \%)$ for non-methane volatile organic compounds, $32.8 \mathrm{Tg}(+17 \%)$ for $\mathrm{NH}_{3}, 36.4 \mathrm{Tg}(+45 \%)$ for $\mathrm{PM}_{10}$, $24.7 \mathrm{Tg}(+42 \%)$ for $\mathrm{PM}_{2.5}, 3.03 \mathrm{Tg}(+35 \%)$ for black carbon, $7.72 \mathrm{Tg}(+21 \%)$ for organic carbon, $182.2 \mathrm{Tg}(+32 \%)$ for $\mathrm{CH}_{4}, 5.80 \mathrm{Tg}(+18 \%)$ for $\mathrm{N}_{2} \mathrm{O}$, and $16.0 \mathrm{Pg}(+57 \%)$ for $\mathrm{CO}_{2}$. By country, China and India were respectively the largest and second largest contributors to Asian emissions. Both countries also had higher growth rates in emissions than others because of their continuous increases in energy consumption, industrial activities, and infrastructure development. In China, emission mitigation measures have been implemented gradually. Emissions of $\mathrm{SO}_{2}$ in China in-
\end{abstract}

creased from 2000 to 2006 and then began to decrease as flue-gas desulphurization was installed to large power plants. On the other hand, emissions of air pollutants in total East Asia except for China decreased from 2000 to 2008 owing to lower economic growth rates and more effective emission regulations in Japan, South Korea, and Taiwan. Emissions from other regions generally increased from 2000 to 2008, although their relative shares of total Asian emissions are smaller than those of China and India. Tables of annual emissions by country and region broken down by sub-sector and fuel type, and monthly gridded emission data with a resolution of $0.25^{\circ} \times 0.25^{\circ}$ for the major sectors are available from the following URL: http://www.nies.go.jp/REAS/.

\section{Introduction}

Estimating anthropogenic emissions of air pollutants and greenhouse gases in Asia, where dramatic spatial and temporal variations of emissions have occurred in the last three decades, is a very important task for understanding and controlling the regional and global atmospheric environment. The earliest Asian emission inventory developed by Kato 
and Akimoto (1992), estimated $\mathrm{SO}_{2}$ and $\mathrm{NO}_{\mathrm{x}}$ emissions of East Asian, Southeast Asian, and South Asian countries in 1975, 1980, and 1985-1987. Akimoto and Narita (1994) provided gridded data sets with a resolution of $1^{\circ} \times 1^{\circ}$. Streets et al. $(2003 \mathrm{a}, \mathrm{b})$ developed detailed emission inventories in Asia for the year 2000 for modeling study of TRACE-P (Transport and Chemical Evolution over the Pacific) field campaigns (Jacob et al., 2003). The TRACE-P project studied Asian outflows of gaseous and aerosol species and their chemical evolution over the western Pacific during the spring of 2001. For TRACE-P's successor mission Intercontinental Chemical Transport Experiment-Phase B (INTEX-B) performed in 2006 (Singh et al., 2009), Zhang et al. (2009a) developed a new emission inventory in Asia for the year 2006. For this effort, Zhang et al. (2009a) improved the methodology for estimating emissions from China by using a detailed technologybased approach that took into consideration recent rapid technology renewal in China. The TRACE-P and INTEX-B data sets have been used not only for their original purpose (e.g. Adhikary et al., 2010) but also for many other atmospheric chemistry modeling studies in Asia (e.g. Liu et al., 2010).

For analyses of long-term trends of the Asian atmospheric environment, Ohara et al. (2007) developed the first inventory of historical and future projected emissions in Asia on the basis of a consistent methodology, the Regional Emission inventory in ASia version 1.1 (REAS 1.1). The target years were from 1980-2003 for historical emissions and 2010-2020 for future projections. REAS 1.1 includes emissions of following species: $\mathrm{SO}_{2}, \mathrm{NO}_{\mathrm{x}}, \mathrm{CO}$, non-methane volatile organic compounds (NMVOC), black carbon (BC), organic carbon (OC), $\mathrm{CO}_{2}, \mathrm{NH}_{3}, \mathrm{CH}_{4}$, and $\mathrm{N}_{2} \mathrm{O}$. The inventory domain includes East, Southeast, and South Asia. Both country and sub-regional emissions and gridded data sets with $0.5^{\circ} \times 0.5^{\circ}$ resolution were provided in annual amounts. REAS 1.1 data have been used for many atmospheric chemistry modeling studies in Asia (e.g. Nagashima et al., 2010). However, energy consumption in the Asian region has grown continuously since 2003, the last year of REAS 1.1 (IEA, 2011). In addition, REAS 1.1 generally did not incorporate known temporal variations in emission factors and removal efficiencies. Zhang et al. (2009a) noted that emission factors in China have changed recently because of implementation of emission control measures especially for coal-fired power plants and new vehicles. Therefore, activity data and parameters of REAS 1.1 have become outdated since 2000 . Furthermore, improvements in computational power and atmospheric chemistry models allow modeling studies to be conducted on, expanded target areas and species, at higher spatial and temporal resolutions.

In response to these developments, we have updated the REAS inventory and issued it as version 2.1. This paper provides a description of methodology, results and discussion of REAS 2.1. In Sect. 2, we describe the revisions to REAS 1.1, and give an overview of the basic methodology of data processing, and updated activity data and emission factors. We also describe the new emissions data from Japan, South Korea, and Taiwan that are incorporated in REAS 2.1. Section 3.1 presents the basic results of Asian and national emissions of each species and their spatial and temporal variations are presented in Sects. 3.2 and 3.3, respectively. We compare the results of REAS 2.1 with REAS 1.1 in Sect. 3.4 and with other inventories in Sect. 3.5. Section 3.6 briefly discusses the uncertainties in REAS 2.1. Information about data distribution is given in Sect. 3.7, and Sect. 4 presents a summary including future plans for REAS.

\section{Methodology}

\subsection{Revisions from REAS version 1}

We developed REAS 2.1 by updating REAS 1.1 (Ohara et al., 2007). Major revisions were as follows (Table 1):

- Two categories of particulate matter $\left(\mathrm{PM}_{10}\right.$ and $\left.\mathrm{PM}_{2.5}\right)$ were added to the target species.

- Target years were changed to 2000-2008, and two new regions, Central Asia and the Asian part of Russia (Asian Russia) were added to the target area.

- Basic activity data, parameters, and methodologies were revised in light of recent studies of the Asian emission inventory.

- Spatial resolution of gridded data was improved to $0.25^{\circ} \times 0.25^{\circ}$, and temporal resolution was increased to monthly.

REAS 2.1 includes most major air pollutants and greenhouse gases. Among primary aerosols, REAS 1.1 considered BC and OC, which have climate impacts, but did not include particulate matter (PM). However, epidemiological studies have shown that high PM concentrations have negative health impacts, including asthma, heart attacks, and premature mortality. In addition, assessment of long-range transport of PM has become important in the Asian region. For these reasons, REAS 2.1 includes emissions of $\mathrm{PM}_{10}$ and $\mathrm{PM}_{2.5}$. Whereas REAS 1.1 extrapolated the NMVOC emissions developed by Klimont et al. (2002a) and Streets et al. (2003a), in REAS 2.1 emissions were calculated from activity data and emission factors for each target year.

REAS 2.1 focuses on emissions after the year 2000. One reason is that Asian emissions increased rapidly after around 2000 (Ohara et al., 2007). Another reason is that penetration of new technologies, abatement equipment, and regulated vehicles have led to gradual changes in Asian emission factors particularly in China, after 2000 (Zhang et al., 2009a; Lu et al., 2010).

Figure 1 shows the inventory domain of REAS 2.1. In addition to the area covered in REAS 1.1, the new inventory includes Asian Russia (Urals, Western and Eastern Siberia, 
Table 1. General information on REAS 2.1.

\begin{tabular}{ll}
\hline Item & Description for targets \\
\hline Species & $\mathrm{SO}_{2}, \mathrm{NO}_{\mathrm{x}}, \mathrm{CO}, \mathrm{NMVOC}, \mathrm{PM}_{10}, \mathrm{PM}_{2.5}, \mathrm{BC}, \mathrm{OC}, \mathrm{NH}_{3}, \mathrm{CH}_{4}, \mathrm{~N}_{2} \mathrm{O}$, and $\mathrm{CO}_{2}$ \\
Years & $2000-2008$ \\
Areas & $\begin{array}{l}\text { East, Southeast, South, and Central Asia. Asian part of Russia } \\
\text { (Far East, Eastern and Western Siberia, and Ural) }\end{array}$ \\
Emission sources & $\begin{array}{l}\text { fuel combustion in power plants, industry, transport, and domestic sectors; } \\
\text { industrial processes; agricultural activities (fertilizer application and }\end{array}$ \\
& $\begin{array}{l}\text { livestock); and others (fugitive emissions, solvent use, human, etc.) } \\
\text { O.25 degree by 0.25 degree }\end{array}$ \\
$\begin{array}{l}\text { Tempotial resolution } \\
\text { Data distribution }\end{array}$ & $\begin{array}{l}\text { monthly } \\
\text { http://www.nies.go.jp/REAS/ }\end{array}$ \\
\hline
\end{tabular}

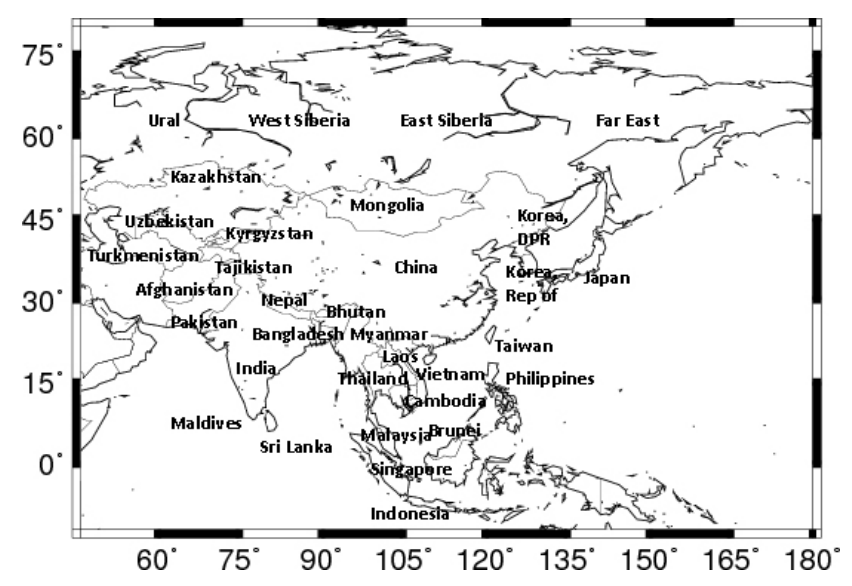

Fig. 1. Inventory domain of REAS 2.1 showing names of all included countries. Western boundary of the Ural region is $60^{\circ} \mathrm{E}$.

and Far East) lying east of the Ural Mountains (east of $60^{\circ} \mathrm{E}$ ) and Central Asia (Kazakhstan, Kyrgyzstan, Tajikistan, Turkmenistan, and Uzbekistan). We also divided China into 33 sub-regions and India into 17 sub-regions to reduce uncertainty in the spatial distribution of emissions. Definitions of the sub-regions are slightly different from those in REAS 1.1, a reflection of changes of districts in each country during the decade after the release of REAS 1.1 (see Table S1 in the Supplement for the list of all target countries and subregions). With respect to Japan, South Korea, and Taiwan, we decided to use inventories from recent studies based on new detailed basic data and parameters (see Sect. 2.5).

Source categories considered in REAS 2.1 are basically the same as in REAS 1.1. For most species, major emission sources are combustion of fossil fuel and biofuel in power plants, industry, road transport, other transport and domestic sectors. Sources other than combustion in the industry sector include production of cement, non-ferrous metals, chemical products, etc. NMVOCs have specific emission sources including solvent use, paint use, and evaporation from road vehicles. Fugitive emissions from coal mining and oil and gas production are considered for $\mathrm{CH}_{4}$, and those from extrac- tion, handling and transport of coal, petroleum and gas are estimated for $\mathrm{CH}_{4}$ and NMVOC.

Basic methodologies for estimating emissions are almost the same as those of REAS 1.1. However, we collected more country-specific and region-specific information from recent studies of emission inventories for Asian countries (see Sects. 2.3 and 2.4). With regard to road transport emissions, we calculated traffic volumes on the basis of the number of vehicles and annual distance traveled for this study rather than energy consumption and fuel economy as in REAS 1.1. In addition, cold start emissions which were ignored in REAS 1.1 were calculated by a simple methodology in REAS 2.1 (see Sect. 2.2.2). REAS 1.1 estimated emissions related to agricultural activities such as fertilizer application and manure management of livestock for $\mathrm{NH}_{3}$, $\mathrm{CH}_{4}, \mathrm{~N}_{2} \mathrm{O}$, and $\mathrm{NO}_{\mathrm{x}}$ up to the year 2000. For REAS 2.1, we used trends of fertilizer use, number of livestock, and corresponding emission factors to extrapolate the agricultural emission data of REAS 1.1 beyond 2000 (see Sect. 2.2.3). We also considered following emission sources of $\mathrm{NH}_{3}$ for REAS 2.1: latrines and human perspiration and respiration. Emissions from natural sources such as vegetation and volcanoes and open biomass burning are not considered in either REAS inventory.

The major role of the REAS inventory is to provide emission input data for atmospheric chemistry models. In addition to improving the spatial resolution of gridded data from $0.5^{\circ} \times 0.5^{\circ}$ to $0.25^{\circ} \times 0.25^{\circ}$, information about power plants as point sources was totally updated (see Sect. 2.3). As for temporal resolution, REAS 1.1 used annual totals for everything except for soil $\mathrm{NO}_{\mathrm{x}}$ emissions, which were monthly totals. In REAS 2.1, we include monthly variations whenever monthly activity statistics or surrogate data were available. Data on weekly and diurnal variations will be considered in future version of REAS. 
(a) Stationary and Mobile Sources
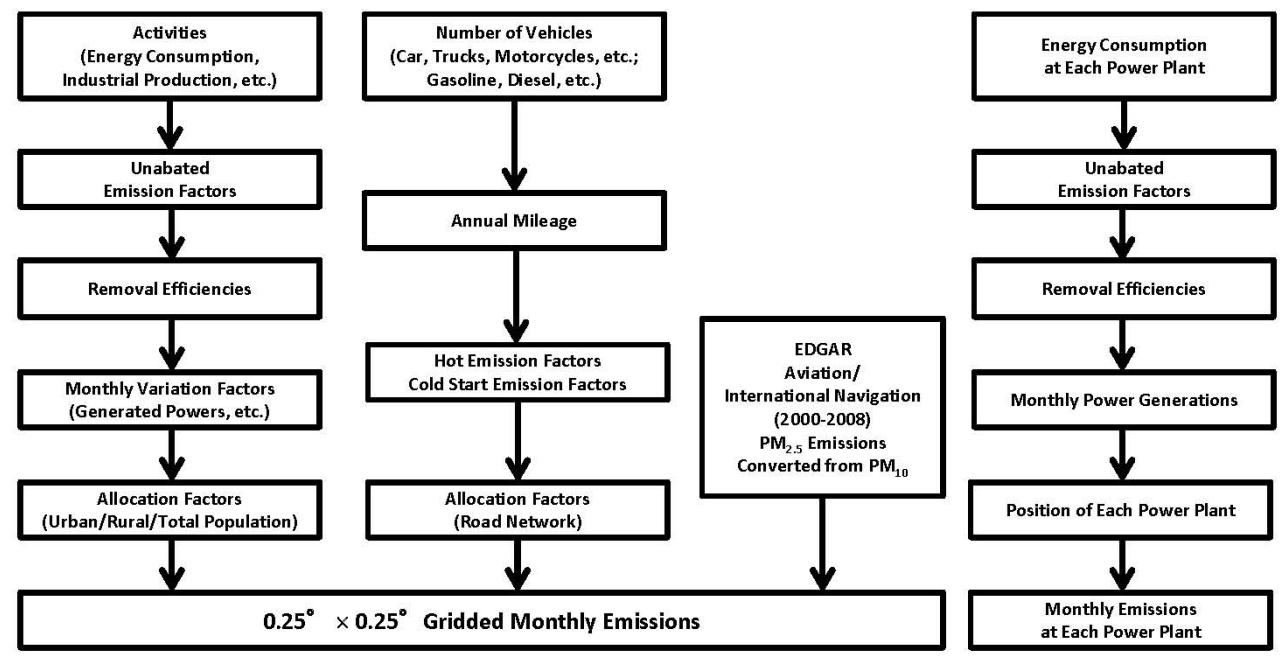

(b) Agricultural Sources

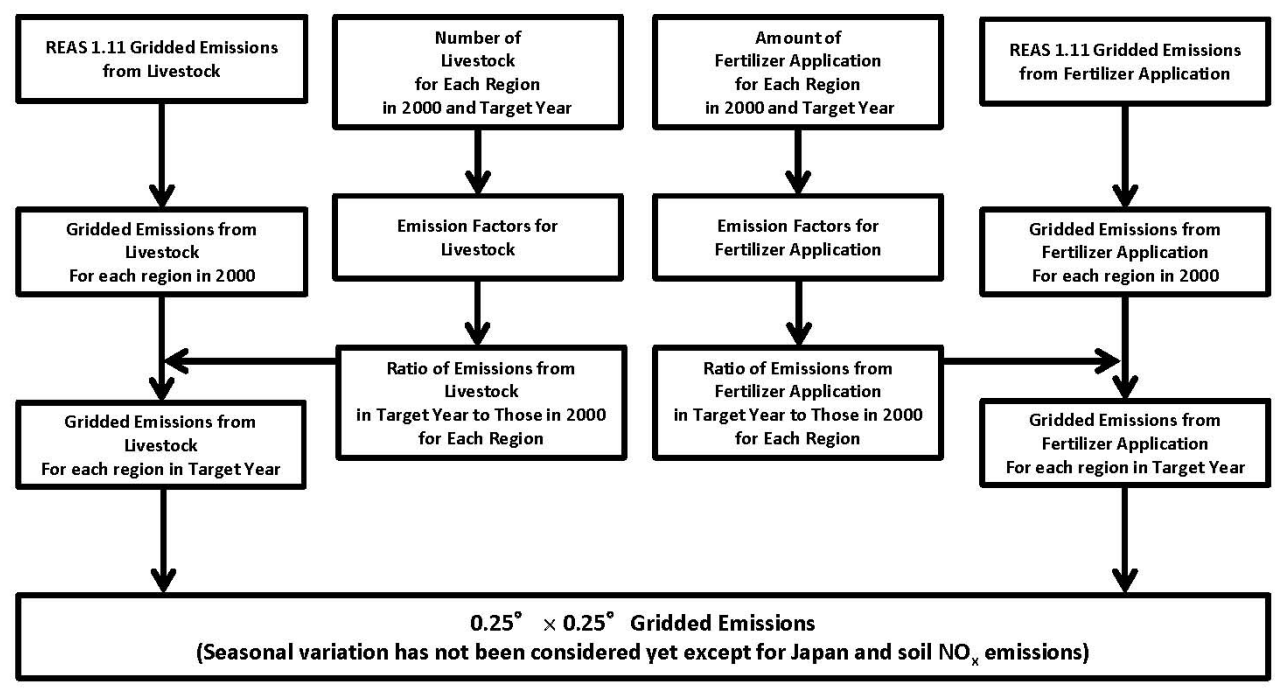

Fig. 2. Schematic flow diagrams showing (a) estimation of emissions from stationary and mobile sources and (b) extrapolation of gridded agricultural emissions based on REAS 1.1 data for the year 2000 .

\subsection{Basic methodology}

\subsubsection{Stationary combustion and industrial processes}

Figure 2a shows the basic procedure used in REAS 2.1 to estimate emissions from stationary combustion and industrial processes. Emissions of $\mathrm{SO}_{2}$ from fuel combustion were calculated from the following equation:

$E=\sum_{i, j}\left\{A_{i, j} \times S_{i, j} \times\left(1-S R_{i, j}\right) \times\left(1-R_{i, j}\right)\right\}$,

where $E$ is emissions from each country and sub-region, $i$ and $j$ are, respectively, fuel and sector types, $A$ is fuel consumption, $S$ is sulfur content of fuel, $S R$ is sulfur retention in ash, and $R$ is removal efficiency. Emissions of other combus- tion species and all species from industrial processes were estimated from the following equation:

$E=\sum_{i, j}\left\{A_{i, j} \times \mathrm{EF}_{i, j} \times\left(1-R_{i, j}\right)\right\}$,

where $E$ is emissions, $i$ is fuel type or sub-category of industry, $j$ is sector type, $A$ is fuel consumption or amount of industrial product, EF is the unabated emission factor, and $R$ is removal efficiency. For fuel combustion sources, the matrix of fuel consumption was prepared based on the energy statistics for each country and sub-region. For power plants, the fuel consumption matrix was created individually if position and fuel consumption data were available, and the power plants were treated as point sources. For industrial process emissions, the amounts of industrial production 
were collected for each country and sub-region. In this study, large industrial plants were not considered as point sources. However, we surveyed the locations and annual capacities of large plants for iron, steel, and cement production. These data were used to develop spatial proxies for grid allocation of emissions. With respect to parameters, region-specific emission factors, sulfur contents of fuel, sulfur retention in ash, and removal efficiencies were prepared for each activity category from a literature survey of Asian emission inventories. See Sects. 2.2.5, 2.3 and 2.4 for details about grid allocation, activity data and emission factors, respectively.

\subsubsection{Road transport}

Figure 2a shows the flow of diagram for estimating emissions from road transport. REAS 2.1 considered not only hot emissions (when the engine is at normal operating temperature), but also separate emission during cold starts. Onroad vehicles were classified as passenger cars, buses, light and heavy trucks, and motorcycles, each of which includes gasoline and diesel vehicles, rural vehicles, and LPG vehicles. In REAS 1.1, emissions were calculated from fuel consumption by vehicle type which was distributed by using fuel economies and corresponding emission factors (Ohara et al., 2007). Because fuel economy data were very limited, the same values were used for many countries. However, no new information of this kind was obtained for use in improving REAS 2.1. Although data of annual distance traveled for Asian countries are also limited, Borken et al. (2008) provided new data for China for 2000. For these reasons, REAS 2.1 calculated hot emissions based on vehicle numbers, annual distance traveled, and emission factors for each vehicle type with the following equation:

$\mathrm{E}_{\mathrm{HOT}}=\sum_{i}\left\{\mathrm{NV}_{i} \times \mathrm{ADT}_{i} \times \mathrm{EF}_{\mathrm{HOT} i}\right\}$,

where $\mathrm{E}_{\mathrm{HOT}}$ is hot emissions, $i$ is vehicle types, $\mathrm{NV}$ is number of registered vehicles, ADT is annual distance traveled, and $\mathrm{EF}_{\mathrm{HOT}}$ is emission factor. Exceptions are $\mathrm{SO}_{2}, \mathrm{CO}_{2}$, and LPG vehicle emissions. $\mathrm{SO}_{2}$ emissions are estimated based on sulfur contents in gasoline and diesel consumed in road transport sector for each country and sub-region assuming sulfur retention in ash is zero. $\mathrm{CO}_{2}$ and LPG vehicle emissions are also calculated by amounts of fuel consumption due to the unit of emission factors selected in this study.

REAS 2.1 includes the cold start emissions for $\mathrm{NO}_{\mathrm{x}}, \mathrm{CO}$, $\mathrm{PM}_{10}, \mathrm{PM}_{2.5}, \mathrm{BC}, \mathrm{OC}$, and NMVOC estimated by the following equation:

$\mathrm{E}_{\mathrm{COLD}}=\sum_{i}\left\{\mathrm{NV}_{i} \times \mathrm{ADT}_{i} \times \mathrm{EF}_{\mathrm{HOT} i} \times \beta_{i} \times F_{i}\right\}$

where $\mathrm{E}_{\mathrm{COLD}}$ is cold emissions, $\beta$ is the fraction of distance traveled driven with a cold engine or with the catalyst operating below the light-off temperature, and $F$ is the correction factor of $\mathrm{EF}_{\mathrm{HOT}}$ for cold start emissions. The parameter $\beta$ and $F$ are functions of average monthly temperature.
Equations for $\beta$ and $F$ and related parameters were taken from the EMEP/EEA emission inventory guidebook 2009 (EEA, 2009). Monthly average surface temperatures for each country and sub-region were calculated from the Japanese $25 \mathrm{yr}$ ReAnalysis (JRA-25) gridded meteorological data set $\left(0.125^{\circ} \times 0.125^{\circ}\right.$ resolution $)$ developed by the Japan Meteorological Agency (JMA) and the Central Research Institute of Electricity Power Industry (CRIEPI) (Onogai et al., 2007).

\subsubsection{Agricultural activities}

Agricultural activities related to emissions of air pollutants and greenhouse gases include fertilizer application $\left(\mathrm{NH}_{3}\right.$, $\mathrm{N}_{2} \mathrm{O}$, and $\left.\mathrm{NO}_{\mathrm{x}}\right)$, manure management $\left(\mathrm{NH}_{3}, \mathrm{~N}_{2} \mathrm{O}, \mathrm{CH}_{4}\right.$, and $\left.\mathrm{NO}_{\mathrm{x}}\right)$, enteric fermentation $\left(\mathrm{CH}_{4}\right)$ of livestock, and rice cultivation $\left(\mathrm{CH}_{4}\right)$. REAS 1.1 developed emission data sets for all these sources over East, Southeast, and South Asia (Yamaji et al., 2003, 2004; Yan et al., 2003a, b, c, 2005). In REAS 2.1, emissions from agricultural activities during 2001 and 2008 were extrapolated from the gridded emission data of REAS 1.1 for 2000 (Fig. 2b). First, activity data such as numbers of livestock and amounts of fertilizer applied were collected from international, national, and regional statistics. Second, the ratio of emissions in the target year to those in 2000 was calculated for each country and sub-region using the activity data and corresponding emission factors from EMEP/EEA emission inventory guidebook 2009 (EEA, 2009). Third, REAS 1.1 gridded emissions for each country and sub-region in 2000 were multiplied by their respective ratios to produce the data for the target years over the REAS 1.1 domain. For the new sub-regions in REAS 2.1 (Asian Russia and Central Asia), we used the Emission Database for Global Atmospheric Research (EDGAR) 4.2 (EC-JRC/PBL, 2011) from 2000 to 2008. Finally, all these sources were used to prepare the agricultural emission data sets of REAS 2.1 between 2000 and 2008. Note that spatial resolution of REAS 1.1 is $0.5^{\circ} \times 0.5^{\circ}$ and unfortunately, we could not obtain surrogate data with which agricultural emissions can be distributed to $0.25^{\circ} \times 0.25^{\circ}$. Therefore, in REAS 2.1, spatial resolution of emissions related to agricultural activities is substantially $0.5^{\circ} \times 0.5^{\circ}$.

\subsubsection{Other sources}

Applications of solvents and paint are major sources of NMVOC emissions, especially in relatively developed countries. Activity data include paint use for architectural and domestic purposes, ink used for publication, and production of many types of solvents. Emissions for these sources were calculated by multiplying corresponding emission factors and activity data.

Some sources of $\mathrm{NH}_{3}$ emissions are directly related to human life. Activity data for human perspiration and respiration were derived from population numbers. For emissions from 
latrines (storage tanks of human excreta), ratios of population in areas with and without sewage service were required.

Fugitive emissions from production, processing, and distribution of fossil fuels are the major sources of $\mathrm{CH}_{4}$. In REAS 2.1, fugitive $\mathrm{CH}_{4}$ emissions were estimated using the Tier 1 methodology of the 2006 IPCC Guidelines for National Greenhouse Gas Inventories (IPCC, 2006). Activity data of fugitive emissions were collected from international, national, and regional energy statistics; these were also used to estimate NMVOC emissions from extraction and processing of fossil fuels. Emissions of $\mathrm{CH}_{4}$ from solid and water waste were also calculated with Tier 1 of the 2006 IPCC guidelines.

For emissions from aviation (both domestic and international at altitudes less than $1 \mathrm{~km}$ ) and international ship navigation, we used gridded data from EDGAR 4.2 for $\mathrm{SO}_{2}$, $\mathrm{NO}_{\mathrm{x}}, \mathrm{CO}, \mathrm{NMVOC}, \mathrm{PM}_{10}, \mathrm{BC}, \mathrm{OC}, \mathrm{CH}_{4}, \mathrm{~N}_{2} \mathrm{O}$, and $\mathrm{CO}_{2}$ between 2000 and 2008. Emissions of $\mathrm{PM}_{2.5}$ were estimated from $\mathrm{PM}_{10}$ emissions using emission factors of $\mathrm{PM}_{2.5}$ and $\mathrm{PM}_{10}$ for ship emissions.

\subsubsection{Seasonal variation and grid allocation}

To estimate monthly emissions, activity data, emission factors, and removal efficiencies are required on a monthly basis. Because such monthly data are very limited, we prepared monthly proxy indexes when appropriate information was available. Otherwise, emissions were treated as constant fluxes. Interannual variability of monthly variation was also considered, when possible.

Monthly generated power was used as a surrogate for combustion emissions from power plants. Monthly production of industrial products and fossil fuels were used not only for activity data but also for proxy indexes of monthly fuel consumption in each industrial sub-category. For the residential sector, monthly variations in fuel consumption for heating were estimated in each grid based on monthly surface temperature in JRA-25 after Streets et al. (2003a). Monthly variations of emission factors and removal efficiencies were ignored except for cold start emissions which depend on ambient temperature as described in Sect. 2.2.2. Emission factors for NMVOC evaporation have temperature dependencies, which will be considered in future work. In REAS 2.1, the monthly variation in agricultural emissions was not considered except for $\mathrm{NO}_{\mathrm{x}}$ from soil in Asia and $\mathrm{NH}_{3}$ in Japan (see Sect. 2.5). Yan et al. (2003c, 2005) developed global soil $\mathrm{NO}_{\mathrm{x}}$ emissions for 2001 with monthly variability and we used the same seasonality for all years between 2000 and 2008. Seasonal variation of agricultural emissions will be also considered in the next version of REAS.

With respect to grid allocation, we used the same methodology of REAS 1.1. As described in Sect. 2.2.1, emissions from power plants for which we had location information were allocated to the appropriate grid cell. For iron, steel, and cement production plants, country and regional emis- sions were allocated using the surrogate data which were developed based on the locations and annual capacities of corresponding plants in each country and region. We used the spatial distribution of rural, urban, and total populations and road network to allocate country- and sub-region-based emissions from area sources to grid cells. In REAS 2.1, population data were updated with the Global Rural-Urban Mapping Project version 1: Urban/Rural Extents with $30^{\prime \prime} \times 30^{\prime \prime}$ grid cells (GRUMPv1) and Gridded Population on the World, version 3 with $2.5^{\prime} \times 2.5^{\prime}$ grid cells $($ GPWv3) (CIESIN et al., 2005,2011 ). Spatial distribution of total population for 2000 , 2005, and 2010 were obtained from GPWv3 and interpolated for each year between 2000 and 2008. Using GRUMPv1 data for 2000 , total population data were divided and aggregated to $0.25^{\circ} \times 0.25^{\circ}$ urban and rural population data. We used the updated total population data to divide the road network data with $0.5^{\circ} \times 0.5^{\circ}$, into $0.25^{\circ} \times 0.25^{\circ}$ grid cells. In other words, the procedure for deriving surrogate data to allocate road transport emissions was not fundamentally changed. Considering the rapid motorization in Asian regions during recent years, the road network data should be updated in a future version of REAS.

\subsection{Activity data}

For most countries, energy consumption data for each fuel type including biofuels and sector categories were taken from the International Energy Agency (IEA) Energy Balances database (IEA, 2011). Total energy consumptions in India from IEA data were distributed to 17 sub-regions by using regional consumption ratios from the Greenhouse Gas and Air Pollution Interaction and Synergies (GAINS) INDIA database (IIASA, 2012). Asian Russia was treated similarly by using national energy consumption for Russia in IEA data and sub-regional data from Mastepanov (2001). For countries whose energy consumptions were not presented in IEA, we used the United Nations (UN) Energy Statistics Database (UN, 2011).

As for China, after Akimoto et al. (2006) and Zhang et al. (2007), we selected province-level energy tables in the China Energy Statistics Yearbook (CESY; National Bureau of Statistics, 2004-2009) with the following modifications. Provincial diesel consumption values were adjusted by factors which are ratios of China's national consumption in IEA to the sum of provincial data in the CESY for each year. Motor gasoline consumption, which was listed in various categories in CESY, was assumed to be consumed in road transport sector except for consumption by agriculture/forestry. Fuel consumption in the industrial sector was distributed to sub-categories based on the statistical yearbook of each province. Data on production of primary and secondary fuels, which were used for estimating industrial process emissions and fugitive emissions, were obtained from the same sources as energy consumption. Note that REAS 1.1 used CESY only for coal, whereas other fossil fuel consumption data 
Table 2. Fuel consumption in China, India, and the rest of the Asian countries in 2000, 2004, and 2008 (PJ yr ${ }^{-1}$ ). (Abbreviations for sectors: $\mathrm{PP}=$ Power plants, IND = Industry, TRA = Transport, DOM = Domestic.)

\begin{tabular}{lccccccccc}
\hline \multicolumn{3}{c}{ China } & \multicolumn{3}{c}{ India } & \multicolumn{3}{c}{ The rest of Asian countries } \\
\hline & 2000 & 2004 & 2008 & 2000 & 2004 & 2008 & 2000 & 2004 & 2008 \\
\hline PP & & & & & & & & & \\
\hline Coal & 12705 & 22288 & 33684 & 5159 & 6184 & 7963 & 4444 & 4858 & 5464 \\
Oil & 723 & 844 & 374 & 383 & 358 & 409 & 1434 & 1176 & 1234 \\
Gas & 192 & 217 & 666 & 387 & 540 & 654 & 4488 & 5523 & 6123 \\
Others & 0 & 0 & 0 & 32 & 45 & 47 & 148 & 169 & 183 \\
\hline IND & & & & & & & & & \\
\hline Coal & 17273 & 24085 & 40829 & 2043 & 2313 & 2732 & 3187 & 3900 & 4801 \\
Oil & 11667 & 15264 & 19231 & 5735 & 6727 & 8397 & 11739 & 12681 & 13072 \\
Gas & 514 & 680 & 1490 & 189 & 269 & 345 & 2312 & 2764 & 3524 \\
Others & 0 & 0 & 0 & 1070 & 1128 & 1182 & 1441 & 1452 & 1579 \\
\hline TRA & & & & & & & & & \\
\hline Oil & 2905 & 4634 & 7524 & 1273 & 1360 & 1766 & 3826 & 4492 & 4745 \\
Others & 227 & 203 & 336 & 7 & 28 & 90 & 362 & 463 & 619 \\
\hline DOM & & & & & & & & & \\
\hline Coal & 3587 & 3797 & 4340 & 348 & 390 & 799 & 509 & 443 & 424 \\
Oil & 1622 & 1984 & 2411 & 931 & 1116 & 1254 & 1554 & 1567 & 1571 \\
Gas & 174 & 438 & 717 & 17 & 29 & 35 & 1943 & 2114 & 2634 \\
Others & 6544 & 8102 & 7771 & 5127 & 5365 & 5613 & 5424 & 5775 & 6084 \\
\hline Total & 58133 & 82536 & 119373 & 22701 & 25852 & 31286 & 42811 & 47377 & 52057 \\
\hline & & & & & & & & & \\
\hline
\end{tabular}

were obtained from IEA. Also, whereas biofuel consumption data for most countries were extrapolated from RAINS-Asia (IIASA, 2001) for the year 1995 and usage of crop residue as biofuel in China was estimated from Yan et al. (2006) in REAS 1.1. These changes may account for part of the difference in emissions between REAS 1.1 and 2.1 (see Sect. 2.5).

Both REAS 1.1 and 2.1 treat power plants as point sources. Although both versions overlap in their coverage from 2000 to 2003, information for point sources was fully updated for REAS 2.1. Figure 3 is a schematic diagram of the development of a new database of point sources that included their locations and fuel consumption of each type. First, $\mathrm{CO}_{2}$ emissions in 2000 and 2007 and locations of power plants were collected from the Carbon Monitoring for Action (CARMA) Database (available at: http://www.carma.org) (Wheeler and Ummel, 2008). Second, information on generation capacity, fuel type, and start and retire years were extracted from the UDI World Electric Power Plants Database (WEPP) (Platts, 2009). Fuel consumption in 2000 and 2007 for each power plant was then estimated by using $\mathrm{CO}_{2}$ emissions from CARMA and emission factors for each fuel type from REAS (see Sect. 2.4). Finally, fuel consumption from 2000 to 2008 was estimated by using the trend of total fuel consumption in the power plant sector for each country and sub-region in which the power plant was located. Note that we used power plants which have position data and whose annual $\mathrm{CO}_{2}$ emissions in CARMA were more than $1 \mathrm{Mt}$. Mostly, total energy consumption in power plants based on CARMA was less than that in statistics of each country and region. Emissions estimated from the differences between statistical and CARMA based energy consumption in power plants were treated as area sources. In addition, we checked the positions of power plants whose $\mathrm{CO}_{2}$ emissions in 2007 were more than $10 \mathrm{Mt}$. They were corrected if we obtained accurate information, but otherwise, the position data were not changed. Therefore, there are still certain uncertainties in power plants emissions in REAS 2.1.

Table 2 summarizes the fuel consumption by fuel types and sectors in China, India, and the rest of Asian countries in 2000, 2004, and 2008. Total energy consumption increased monotonically in Asia and growth rates from 2000 to 2008 were about $+105 \%$ in China, $+38 \%$ in India, and $+22 \%$ in the rest of Asian countries. In particular, increase rates in China were exceedingly high for coal consumption in power plants $(+165 \%)$ and industry sector $(+136 \%)$ and oil consumption in transport sector $(+159 \%)$. Growth rates for coal consumption in power plants in India and those in industry in the rest of Asian countries were also large (more than $50 \%$ ). Relative ratios of total energy consumption in 2008 were $59 \%$ for China, $15 \%$ for India, and $26 \%$ for the rest of 


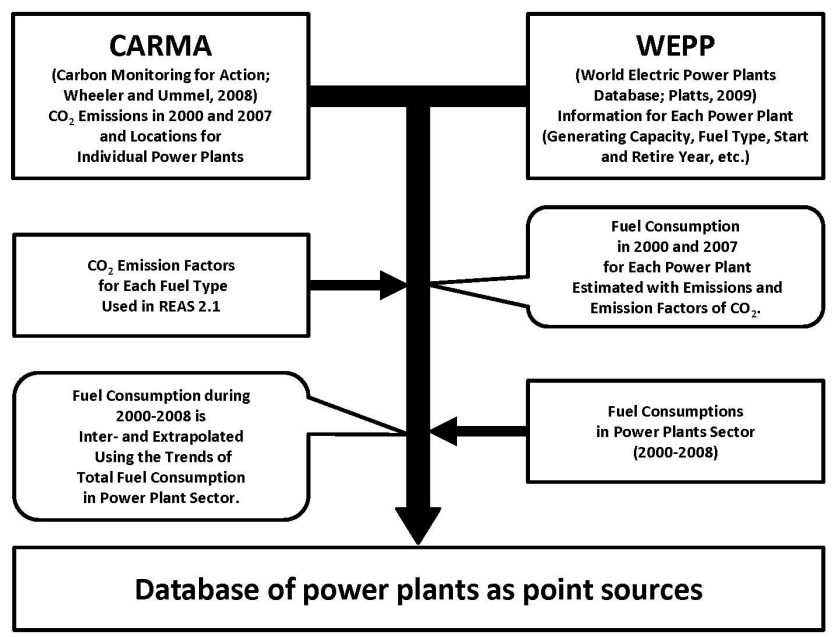

Fig. 3. Schematic flow diagram for developing a database of basic data for power plants as point sources.

Asian countries. In 2008, the share of total coal consumption in China was nearly $80 \%$ of Asia's total.

Activity data for sources other than energy came from a variety of international, national, and regional statistics and studies. For example, monthly production of iron and steel was obtained from the Steel Statistical Yearbook (World Steel Association, 2010). Annual production of non-ferrous metals and non-metallic minerals came from the U.S. Geological Survey Minerals Yearbook (USGS, 2004-2008) and monthly data were available for several countries from statistics of each country. Vehicle numbers for cars, buses, trucks, and motor cycles were from the World Road Statistics (IRF, 2006-2010) and then subdivided into vehicle types by using the national and sub-regional statistics and database of the GAINS model. For China, numbers of vehicles of each type in 2000 were taken from Borken et al. (2008), and numbers from 2001 to 2008 were extrapolated by using trends from the China Statistical Yearbook (National Bureau of Statistics, 2001-2009). Agricultural activity data, such as numbers of livestock and amounts of applied fertilizers, were collected from the Food and Agriculture Organization Corporate Statistics Database (FAOSTAT) (FAO, 2011) and national and sub-regional statistics. The China Data Center of the University of Michigan, in its China Data Online resource, provided monthly statistics for each province such as production of steel, and cement, and power generation. We also used the basic data from the GAINS model when they were the only available information. If no activity data were found, we assumed that there were no emissions related to the activities, although this might instead be due to a lack of records.

\subsection{Emission factors}

REAS 1.1 obtained parameters such as emission factors and removal efficiencies from 1980 to 2003 from many sources, including Asian emission inventories although the number of inventories of Asian countries was limited. In REAS 2.1, we continued to use the parameters of REAS 1.1 as default settings for 2000. Some parameters that were not part of REAS 1.1 needed to be determined for REAS 2.1. For Asian Russia and Central Asia, parameters from REAS 1.1 that were not country- or region-specific were used for default values. Default emission factors for $\mathrm{PM}_{10}$ and $\mathrm{PM}_{2.5}$ were based on Klimont et al. (2002b) and AP-42 (US EPA, 1995) and for consistency, those for $\mathrm{BC}$ and $\mathrm{OC}$ were taken from Kupiainen and Klimont (2004). Default emission factors for total NMVOC and speciation factors for each NMVOC species were taken from Klimont et al. (2002a) and Streets et al. (2003a). In Asia, the influence of emission abatement equipment increased after 2000, especially for $\mathrm{SO}_{2}$ and aerosols. In REAS 2.1, settings of the GAINS model for $\mathrm{SO}_{2}$, $\mathrm{PM}_{10}$, and $\mathrm{PM}_{2.5}$ for 2000, 2005, and 2010 were adopted through linear interpolation as default settings. These were then updated for target countries and sub-regions after a survey of more recent studies when appropriate.

Many recently published emission inventories for China have been incorporated in REAS 2.1 as follows: Sulfur content in fuels, sulfur retention in ash, and penetration of flue gas desulphurization (FGD) from 2000 to 2008 were from Zhao et al. $(2008,2010)$ and Lu et al. (2010). Emission factors for $\mathrm{NO}_{\mathrm{x}} \mathrm{CO}, \mathrm{NMVOC}$, and primary aerosols $\left(\mathrm{PM}_{10}, \mathrm{PM}_{2.5}, \mathrm{BC}\right.$, and $\left.\mathrm{OC}\right)$ except for road transport and cement production, were from Zhang et al. (2007), Streets et al. (2006), Wei et al. (2008) and Lei et al. (2011a), respectively. Emission factors for $\mathrm{NO}_{\mathrm{x}} \mathrm{CO}$, and aerosols from cement production were based on Lei et al. (2011b). For road transport, temporal variations of emission factors due to control strategies and policies were estimated from 2000 to 2008 based on Borken et al. (2008) and Wu et al. (2011). Tables $3 \mathrm{a}, 4$, and 5 provide the emission factors for stationary combustion, road transport, and industrial process sources in China for 2000 and 2008 (or averaged between 2000 and 2008), respectively. Net emission factors for $\mathrm{SO}_{2}$ and $\mathrm{PM}$ for coal-fired power plants were largely reduced due to the introduction of abatement equipment such as FGD for $\mathrm{SO}_{2}$ and electrostatic precipitators for PM (Lu et al., 2010; Lei et al., 2011a). Net emission factors of $\mathrm{NO}_{\mathrm{x}}$ for coal-fired power plants were also decreased but reduction rate was relatively small. Net emission factor of $\mathrm{CO}$ for coal combustion in industry was decreased but that of $\mathrm{NO}_{\mathrm{x}}$ was slightly increased. This is because relative ratios of cement produced from shaft kilns with high $\mathrm{CO}$ emission factors were decreased and instead, those from precalciner kilns with high $\mathrm{NO}_{\mathrm{x}}$ emission factors were increased (Lei et al., 2011b). In general, emission factors for road vehicles were reduced from 2000 to 2008 because of implementation of new vehicle emission 
Table 3. Net emission factors ( $\mathrm{t} \mathrm{PJ}^{-1}$ ) of $\mathrm{SO}_{2}, \mathrm{NO}_{\mathrm{x}}, \mathrm{CO}, \mathrm{PM}_{10}, \mathrm{PM}_{2.5}, \mathrm{BC}, \mathrm{OC}$, and NMVOC for stationary combustion and transport other than road in (a) China, (b) South Asia, and (c) the rest of Asian countries. The values without parenthesis are emission factors averaged between 2000 and 2008 and with parenthesis are those for 2000 and 2008, respectively.

\begin{tabular}{|c|c|c|c|c|c|c|}
\hline \multicolumn{7}{|l|}{ (a) China } \\
\hline & \multicolumn{3}{|c|}{ Power Plants } & \multicolumn{3}{|c|}{ Industry } \\
\hline & Coal & Oil & Gas & Coal & Oil & Gas \\
\hline $\mathrm{SO}_{2}$ & $(792,363)$ & 568 & 0.245 & $(719,579)$ & 265 & 0.239 \\
\hline $\mathrm{NO}_{\mathrm{x}}$ & $(354,319)$ & 278 & 205 & $(205,241)$ & 158 & 99.9 \\
\hline $\mathrm{CO}$ & 114 & 27.6 & 20.5 & $(3525,3286)$ & 17.6 & 15.0 \\
\hline $\mathrm{PM}_{10}$ & $(144,84.1)$ & 15.1 & 0.0 & 133 & 15.7 & 0.0 \\
\hline $\mathrm{PM}_{2.5}$ & $(86.9,50.2)$ & 11.9 & 0.0 & 57.1 & 12.1 & 0.0 \\
\hline $\mathrm{BC}$ & $(0.197,0.114)$ & 1.28 & 0.0 & 13.7 & 1.76 & 0.0 \\
\hline $\mathrm{OC}$ & 0.0 & 0.568 & 0.0 & 2.73 & 0.726 & 0.0 \\
\hline \multirow[t]{2}{*}{ NMVOC } & 1.94 & 3.14 & 5.13 & 4.67 & 2.86 & 5.00 \\
\hline & \multicolumn{2}{|c|}{ Transport other than road } & \multicolumn{3}{|c|}{ Domestic } & All \\
\hline & Oil & Others & Coal & Oil & Gas & Biofuel \\
\hline $\mathrm{SO}_{2}$ & 309 & 680 & 713 & 46.7 & 0.225 & 46.5 \\
\hline $\mathrm{NO}_{\mathrm{x}}$ & 1403 & 250 & 104 & 433 & 48.6 & 83.9 \\
\hline $\mathrm{CO}$ & 14.8 & 150 & 3508 & 12.9 & 89.1 & 5747 \\
\hline $\mathrm{PM}_{10}$ & 16.8 & 0.0 & 369 & 14.5 & 0.0 & 464 \\
\hline $\mathrm{PM}_{2.5}$ & 13.4 & 105 & 252 & 14.2 & 0.0 & 449 \\
\hline $\mathrm{BC}$ & 2.30 & 20.3 & $(46.9,36.0)$ & 2.75 & 0.0 & 74.4 \\
\hline $\mathrm{OC}$ & 0.695 & 4.18 & $(108,78.9)$ & 1.27 & 0.0 & 288 \\
\hline NMVOC & 2.84 & 4.62 & 110 & 41.4 & 4.71 & 446 \\
\hline \multicolumn{7}{|c|}{ (b) South Asia ${ }^{a}$} \\
\hline & \multicolumn{3}{|c|}{ Power Plants } & \multicolumn{3}{|c|}{ Industry } \\
\hline & Coal & Oil & Gas & Coal & Oil & Gas \\
\hline $\mathrm{SO}_{2}$ & 573 & 996 & 0.240 & 717 & 898 & 0.239 \\
\hline $\mathrm{NO}_{\mathrm{x}}$ & 338 & 444 & 201 & 250 & 167 & 100 \\
\hline $\mathrm{CO}$ & 283 & 143 & 20.1 & 4904 & 123 & 15.0 \\
\hline $\mathrm{PM}_{10}$ & 247 & 13.6 & 0.0 & 142 & 18.2 & 0.0 \\
\hline $\mathrm{PM}_{2.5}$ & 101 & 11.8 & 0.0 & 55.0 & 14.8 & 0.0 \\
\hline $\mathrm{BC}$ & 1.03 & 0.244 & 0.0 & 12.1 & 0.988 & 0.0 \\
\hline $\mathrm{OC}$ & 2.66 & 1.23 & 0.0 & 1.44 & 1.44 & 0.0 \\
\hline \multirow[t]{3}{*}{ NMVOC } & 7.92 & 5.27 & 5.02 & 20.0 & 5.00 & 4.99 \\
\hline & \multicolumn{2}{|c|}{ Transport other than road } & \multicolumn{3}{|c|}{ Domestic } & All \\
\hline & Oil & Others & Coal & Oil & Gas & Biofuel \\
\hline $\mathrm{SO}_{2}$ & 341 & 317 & 383 & 259 & 0.239 & 58.9 \\
\hline $\mathrm{NO}_{\mathrm{x}}$ & 1198 & 250 & 113 & 67.9 & 48.8 & 148 \\
\hline $\mathrm{CO}$ & 998 & 100 & 5566 & 92.1 & 114 & 5201 \\
\hline $\mathrm{PM}_{10}$ & 61.9 & 154 & 837 & 26.3 & 0.0 & 368 \\
\hline $\mathrm{PM}_{2.5}$ & 61.1 & 46.4 & 651 & 24.2 & 0.0 & 350 \\
\hline $\mathrm{BC}$ & 5.12 & 8.82 & 97.6 & 1.71 & 0.0 & 56.3 \\
\hline $\mathrm{OC}$ & 4.97 & 1.05 & 416 & 4.63 & 0.0 & 254 \\
\hline NMVOC & 159 & 0.0 & 200 & 33.7 & 5.00 & 1158 \\
\hline
\end{tabular}

(c) The rest of Asian countries ${ }^{\mathrm{b}}$

\begin{tabular}{|c|c|c|c|c|c|c|}
\hline & \multicolumn{3}{|c|}{ Power Plants } & \multicolumn{3}{|c|}{ Industry } \\
\hline & Coal & Oil & Gas & Coal & Oil & Gas \\
\hline $\mathrm{SO}_{2}$ & 796 & 810 & 0.240 & 381 & 538 & 0.239 \\
\hline $\mathrm{NO}_{\mathrm{x}}$ & 297 & 359 & 118 & 262 & 157 & 56.4 \\
\hline $\mathrm{CO}$ & 23.3 & 24.4 & 20.1 & 1469 & 35.3 & 24.0 \\
\hline $\mathrm{PM}_{10}$ & 125 & 12.7 & 0.0 & 186 & 10.4 & 0.0 \\
\hline $\mathrm{PM}_{2.5}$ & 37.7 & 8.43 & 0.0 & 64.9 & 6.53 & 0.0 \\
\hline BC & 0.075 & 0.656 & 0.0 & 12.3 & 0.479 & 0.0 \\
\hline $\mathrm{OC}$ & 0.0 & 0.037 & 0.0 & 2.60 & 0.180 & 0.0 \\
\hline \multirow[t]{3}{*}{ NMVOC } & 3.26 & 4.60 & 5.03 & 13.1 & 4.38 & 5.00 \\
\hline & \multicolumn{2}{|c|}{ Transport other than road } & \multicolumn{3}{|c|}{ Domestic } & All \\
\hline & Oil & Others & Coal & Oil & Gas & Biofuel \\
\hline $\mathrm{SO}_{2}$ & 540 & 1.87 & 322 & 197 & 0.239 & 53.1 \\
\hline $\mathrm{NO}_{\mathrm{x}}$ & 1398 & 100 & 129 & 93.2 & 61.0 & 78.4 \\
\hline $\mathrm{CO}$ & 241 & 15.3 & 4324 & 348 & 77.3 & 5765 \\
\hline $\mathrm{PM}_{10}$ & 9.06 & 501 & 104 & 4.18 & 0.0 & 382 \\
\hline $\mathrm{PM}_{2.5}$ & 6.14 & 151 & 44.4 & 3.64 & 0.0 & 370 \\
\hline $\mathrm{BC}$ & 0.977 & 28.6 & 8.17 & 0.551 & 0.0 & 74.0 \\
\hline $\mathrm{OC}$ & 5.72 & 6.03 & 6.53 & 0.334 & 0.0 & 296 \\
\hline NMVOC & 39.9 & 5.00 & 113 & 44.4 & 5.00 & 971 \\
\hline
\end{tabular}

${ }^{a}$ Emission factors for India are used for other South Asian countries.

b Japan, South Korea, and Taiwan are not included. 
Table 4. Emission factors $\left(\mathrm{g} \mathrm{km}^{-1}\right)$ of $\mathrm{NO}_{\mathrm{x}}, \mathrm{CO}, \mathrm{PM}_{10}, \mathrm{PM}_{2.5}, \mathrm{BC}, \mathrm{OC}$ and NMVOC for road transport in China for 2000 and 2008.

\begin{tabular}{|c|c|c|c|c|c|}
\hline & \multicolumn{2}{|c|}{ Gasoline } & \multicolumn{2}{|c|}{ Diesel } & \multirow[b]{2}{*}{ Motorcycle } \\
\hline & Light & Heavy & Light & Heavy & \\
\hline \multicolumn{6}{|l|}{$\mathrm{NO}_{\mathrm{x}}$} \\
\hline 2000 & $1.40-2.70$ & $3.80-4.00$ & $1.40-4.30$ & $12.0-13.6$ & 0.200 \\
\hline 2008 & $0.700-1.63$ & $1.05-2.89$ & $0.975-2.99$ & $5.07-9.50$ & $0.062-0.101$ \\
\hline \multicolumn{6}{|l|}{$\mathrm{CO}$} \\
\hline 2000 & $37.5-66.8$ & $101-146$ & $10.9-12.1$ & $18.0-20.6$ & $13.1-15.0$ \\
\hline 2008 & $12.2-22.9$ & $43.6-59.5$ & $5.28-6.16$ & $9.00-10.5$ & $5.15-7.97$ \\
\hline \multicolumn{6}{|c|}{$\mathrm{PM}_{10}$} \\
\hline 2000 & $0.020-0.210$ & 0.350 & $0.017-0.280$ & $0.620-1.010$ & 0.200 \\
\hline 2008 & $0.009-0.174$ & $0.259-0.334$ & $0.002-0.191$ & $0.225-0.733$ & $0.073-0.182$ \\
\hline \multicolumn{6}{|c|}{$\mathrm{PM}_{2.5}$} \\
\hline 2000 & $0.018-0.191$ & 0.318 & $0.017-0.266$ & $0.607-0.989$ & 0.182 \\
\hline 2008 & $0.008-0.158$ & $0.235-0.304$ & $0.002-0.181$ & $0.221-0.718$ & $0.067-0.166$ \\
\hline \multicolumn{6}{|l|}{$\mathrm{BC}$} \\
\hline 2000 & $0.006-0.061$ & 0.101 & $0.003-0.159$ & $0.352-0.573$ & 0.058 \\
\hline 2008 & $0.003-0.050$ & $0.075-0.097$ & $0.000-0.108$ & $0.128-0.416$ & $0.021-0.053$ \\
\hline \multicolumn{6}{|l|}{$\mathrm{OC}$} \\
\hline 2000 & $0.006-0.064$ & 0.107 & $0.001-0.051$ & $0.112-0.182$ & 0.061 \\
\hline 2008 & $0.003-0.053$ & $0.079-0.102$ & $0.000-0.034$ & $0.041-0.132$ & $0.022-0.056$ \\
\hline \multicolumn{6}{|c|}{ NMVOC } \\
\hline 2000 & $4.73-11.5$ & $9.68-14.2$ & $2.36-2.68$ & $4.17-5.44$ & $5.57-5.82$ \\
\hline 2008 & $1.62-4.08$ & $3.34-5.54$ & $0.755-0.987$ & $1.78-2.71$ & $2.24-4.18$ \\
\hline
\end{tabular}

Table 5. Net emission factors ( $\mathrm{t} \mathrm{kt}^{-1}$ product) of $\mathrm{CO}, \mathrm{PM}_{10}, \mathrm{PM}_{2.5}, \mathrm{BC}, \mathrm{OC}$, and $\mathrm{SO}_{2}$ for major industrial process sources in China. The values without parentheses are emission factors averaged between 2000 and 2008 and with parentheses are those for 2000 and 2008 , respectively.

\begin{tabular}{lccccccc}
\hline & Iron & Steel & Cokes & Refinery & Cement & Sulfuric Acid & Copper \\
\hline $\mathrm{CO}$ & $(40.5,19.2)$ & $(47.0,50.1)$ & $(6.00,3.24)$ & 0.0 & 0.0 & 0.0 & 0.0 \\
$\mathrm{PM}_{10}$ & $(3.34,2.96)$ & $(0.899,0.651)$ & $(4.87,4.06)$ & 0.047 & $(4.34,2.02)$ & 0.0 & 192 \\
$\mathrm{PM}_{2.5}$ & $(2.81,2.49)$ & $(0.705,0.497)$ & $(3.37,2.87)$ & 0.043 & $(3.05,1.48)$ & 0.0 & 177 \\
$\mathrm{BC}$ & $(0.320,0.163)$ & 0.0 & $(1.07,0.812)$ & 0.0 & $(0.020,0.010)$ & 0.0 & 0.0 \\
$\mathrm{OC}$ & $(0.062,0.029)$ & $(0.061,0.044)$ & $(1.22,0.912)$ & 0.0 & $(0.031,0.014)$ & 0.0 & 0.0 \\
$\mathrm{SO}_{2}$ & 0.0 & 0.0 & 1.55 & 0.201 & 0.0 & 16.5 & 191 \\
\hline
\end{tabular}

standards in China (Zhang et al., 2009a). For industrial process sources, net emission factors for PM were generally decreased due to the penetration of abatement equipment such as wet scrubbers, electrostatic precipitators, and fabric filters (Lei et al., 2011a).

Emission inventories for countries other than China are still limited. Emission factors for India were updated as follows: $\mathrm{NO}_{\mathrm{x}}$ and $\mathrm{CO}$ emission factors for power plants were from Chakraborty et al. (2008); $\mathrm{SO}_{2}$ and $\mathrm{NO}_{\mathrm{x}}$ emission fac- tors for biofuel combustion were from Gadi et al. (2003) and Gurjar et al. (2004); emission factors for aerosols from fossil fuel combustion were from Reddy and Venkataraman (2002a); and those from biofuel combustion were from Reddy and Venkataraman (2002b) and Venkataraman et al. (2005). These updated emission factors for India were also used for other South Asian countries. For Asian Russia and Central Asian countries, $\mathrm{NO}_{\mathrm{x}}$ emission factors were taken from Ryaboshapko et al. (1996). We could not find 
other country- or region-specific emission factors. In Table $3 \mathrm{~b}$ and $\mathrm{c}$, net emission factors for stationary combustion in South Asia and the rest of Asian countries are also presented, respectively. Note that Japan, South Korea, and Taiwan were not included in the rest of Asian countries in Table $3 \mathrm{c}$ because their emissions were obtained from recent studies as described in Sect. 2.1 (See also Sect. 2.5).

\subsection{Japan, South Korea, and Taiwan}

As described in Sect. 2.1, REAS 2.1 used improved emission inventories for Japan, South Korea, and Taiwan from recent works with detailed information about activity data and parameters.

Except for the maritime sector, emissions in Japan were from the Japan Auto-Oil Program (JATOP) Emission Inventory-Data Base (JEI-DB) developed by JPEC (2012a, b, c). JEI-DB includes vehicle emissions in 2000, 2005, and 2010 and non-vehicle emissions in 2000 and 2005 for $\mathrm{SO}_{2}$, $\mathrm{NO}_{\mathrm{x}}, \mathrm{CO}, \mathrm{NMVOC}, \mathrm{PM}$, and $\mathrm{NH}_{3}$, with monthly variations and spatial resolution of $1 \mathrm{~km}$. Emissions between 2001 and 2004 and between 2006 and 2008 were derived by using the interannual variations of activity data and effects of emission regulations in Japan. Note that JEI-DB includes $\mathrm{CO}_{2}$ emissions only from vehicles. Therefore, non-vehicle $\mathrm{CO}_{2}$ emissions were estimated using the same activity data for other species and emission factors used for REAS 2.1. For NMVOC evaporative emissions from stationary sources, we used data developed by Ministry of the Environment of Japan (MOEJ, 2009). For the maritime sector, we used the database developed by the Ocean Policy Research Foundation (OPRF, 2012), which includes gridded emissions for 2005 from inland navigation, fishing fleets, and bunker fuel consumption by seagoing ships in Japanese national waters for $\mathrm{SO}_{2}, \mathrm{NO}_{\mathrm{x}}$, $\mathrm{CO}$, NMVOC, $\mathrm{PM}_{10}, \mathrm{CH}_{4}, \mathrm{~N}_{2} \mathrm{O}$, and $\mathrm{CO}_{2}$. For other years between 2000 and 2008, emissions were extrapolated based on reported energy consumptions.

For emissions from South Korea, we relied on the Clean Air Policy Support System (CAPSS) developed by Lee et al. (2011). City-level and province-level emissions for each sector and fuel type are available from the National Air Pollutants Emission website maintained by the National Institute of Environmental Research-Korea (http://airemiss.nier. go.kr). For REAS 2.1 we obtained emissions for $\mathrm{SO}_{2}, \mathrm{NO}_{\mathrm{x}}$, CO, NMVOC, and $\mathrm{PM}_{10}$ from 2000 to 2008 and allocated them to grids based on the population distribution within each city and province.

For Taiwan, we obtained data on $\mathrm{SO}_{2}, \mathrm{NO}_{\mathrm{x}}, \mathrm{CO}$, NMVOC, $\mathrm{PM}_{10}$ and $\mathrm{PM}_{2.5}$ emissions developed by the Environmental Protection Administration of Taiwan at its website (http: //ivy2.epa.gov.tw/air-ei). We obtained detailed emissions for each sector and fuel type in 2000, 2003 and 2007 as well as historical and projected total emissions between 1987 and 2021. We estimated emissions between 2000 and 2008 based on the trends of total emissions and then used the updated allocation factors described in Sect. 2.2.5 to distribute them into grids.

There are several data categories that were not included in these national inventories. Emissions of BC and OC (and $\mathrm{PM}_{2.5}$ for Japan and South Korea) were converted from those of $\mathrm{PM}_{2.5}\left(\mathrm{PM}_{10}\right.$ for Japan and South Korea) using known relations among emission factors for $\mathrm{BC}, \mathrm{OC}, \mathrm{PM}_{2.5}$, and $\mathrm{PM}_{10}$. We used the same methodologies described previously for other countries to develop emission data sets for $\mathrm{NH}_{3}$, $\mathrm{CH}_{4}$, and $\mathrm{N}_{2} \mathrm{O}$.

\section{Results and discussion}

\subsection{Asian and national emissions for each species}

Table 6 summarizes national emissions for each species in 2008, total annual Asian emissions from 2000 to 2008, and ratios of total Asian emissions between 2008 and 2000. Figures 4, 5, and 6 show the annual emissions from 2000 to 2008 , divided by country/sub-region and by sector, for gaseous pollutant species, primary aerosols, and greenhouse gases, respectively. (In the Supplement, Table S2 presents national emissions for 2000-2008, and Table S3 presents emissions for each sector and fuel type in 2000, 2004, and 2008 in each nation/sub-region). Table 7 lists the relative contribution of national/sub-regional emissions to total Asian emissions.

\subsection{1 $\mathrm{SO}_{2}$}

Total $\mathrm{SO}_{2}$ emissions in 2008 (growth rate between 2000 and 2008) in REAS 2.1 are $56.9 \mathrm{Tg}(+34 \%)$ for Asia, $33.5 \mathrm{Tg}(+46 \%)$ for China, $10.1 \mathrm{Tg}(+53 \%)$ for India, $1.6 \mathrm{Tg}$ $(-12 \%)$ for East Asia outside China (OEA), $4.2 \mathrm{Tg}(+13 \%)$ for Southeast Asia (SEA), 1.4 Tg $(+18 \%$ ) for South Asia outside India (OSA), and $6.2 \mathrm{Tg}(+2 \%)$ for Asian Russia and Central Asia (RCA). The majority of Asian $\mathrm{SO}_{2}$ emissions come from China (54-62\% during the period 2000-2008), followed by India (15-18\% during the period 2000-2008). The trends of total Asian emissions for this and most other species are dominated by China.

The fact that Asian $\mathrm{SO}_{2}$ emissions increased monotonically from 2000 to 2006 and then began to decrease reflects trends of emissions in China and the power plant sector; a growing number of coal-fired power plants have been equipped with FGD in China (Fig. 4a and b). REAS 2.1 used average FGD penetration rates in Chinese coal-fired power plants from Lu et al. (2010), which showed an increase from $4 \%$ in 2004 to $54 \%$ in 2008. Whereas $\mathrm{SO}_{2}$ and $\mathrm{CO}_{2}$ emissions from power plants in China increased by $71 \%$ and $91 \%$, respectively from 2000 to 2005 , sulfur emissions subsequently fell, while $\mathrm{CO}_{2}$ emissions continued to climb. Thus in $2008, \mathrm{SO}_{2}$ emissions were $20 \%$ greater than in 2000 , while $\mathrm{CO}_{2}$ emissions were $149 \%$ greater. These tendencies were most prominent in Inner Mongolia, where many new power plants were constructed (Zhang et al., 2009b). Inner 

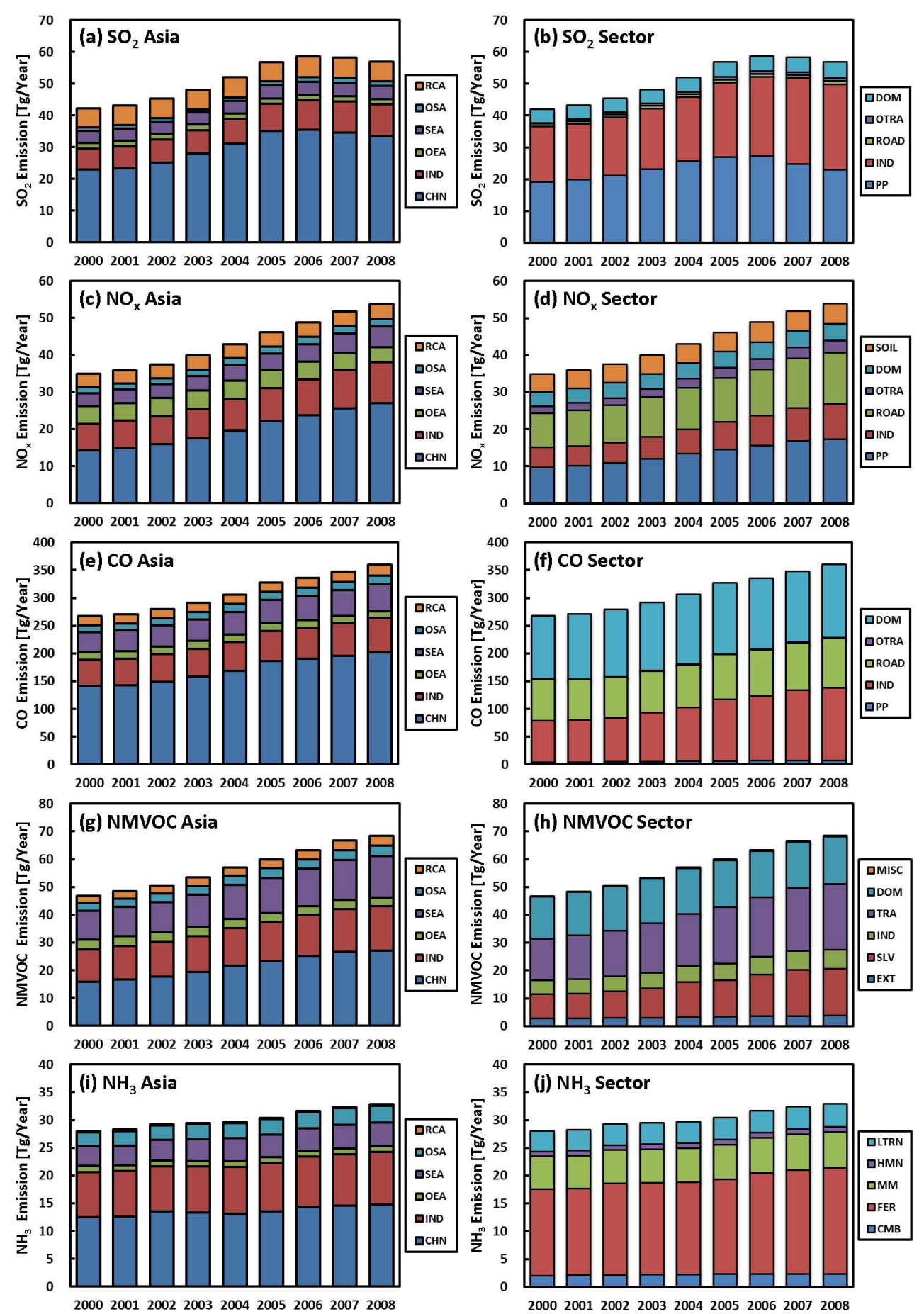

Fig. 4. Annual emissions of $\mathrm{SO}_{2}, \mathrm{NO}_{\mathrm{x}}, \mathrm{CO}, \mathrm{NMVOC}$, and $\mathrm{NH}_{3}$ in Asia from 2000 to 2008 for each region (left panels) and sector (right panels). Regions: $\mathrm{CHN}=\mathrm{China}, \mathrm{IND}=$ India, OEA = East Asia outside China, $\mathrm{SEA}=$ Southeast Asia, OSA = South Asia outside India, and RCA = Asian Russia and Central Asia. Sectors: PP = Power plants, IND = Industry, ROAD = Road transport, OTRA = Other transport, $\mathrm{DOM}=$ Domestic, $\mathrm{SOIL}=$ Soil, $\mathrm{EXT}=$ Extraction processes, $\mathrm{SLV}=$ Solvent and paint use, WASTE $=$ Waste treatment, $\mathrm{CMB}=\mathrm{Combustion}$, $\mathrm{FER}=$ Fertilizer application, $\mathrm{MM}=$ Manure management, and $\mathrm{HMN}=$ Human perspiration and respiration, and LTRN $=\mathrm{Latrines}$.

Mongolia's $\mathrm{CO}_{2}$ emissions increased by a factor of 4.7 from 2000 to 2008, whereas its $\mathrm{SO}_{2}$ emissions between 2000 and 2008 increased less than $30 \%$.
Emissions from the industry sector in Asia increased almost monotonically between 2000 and 2008, and growth rates became larger after 2005. Industrial emissions from 

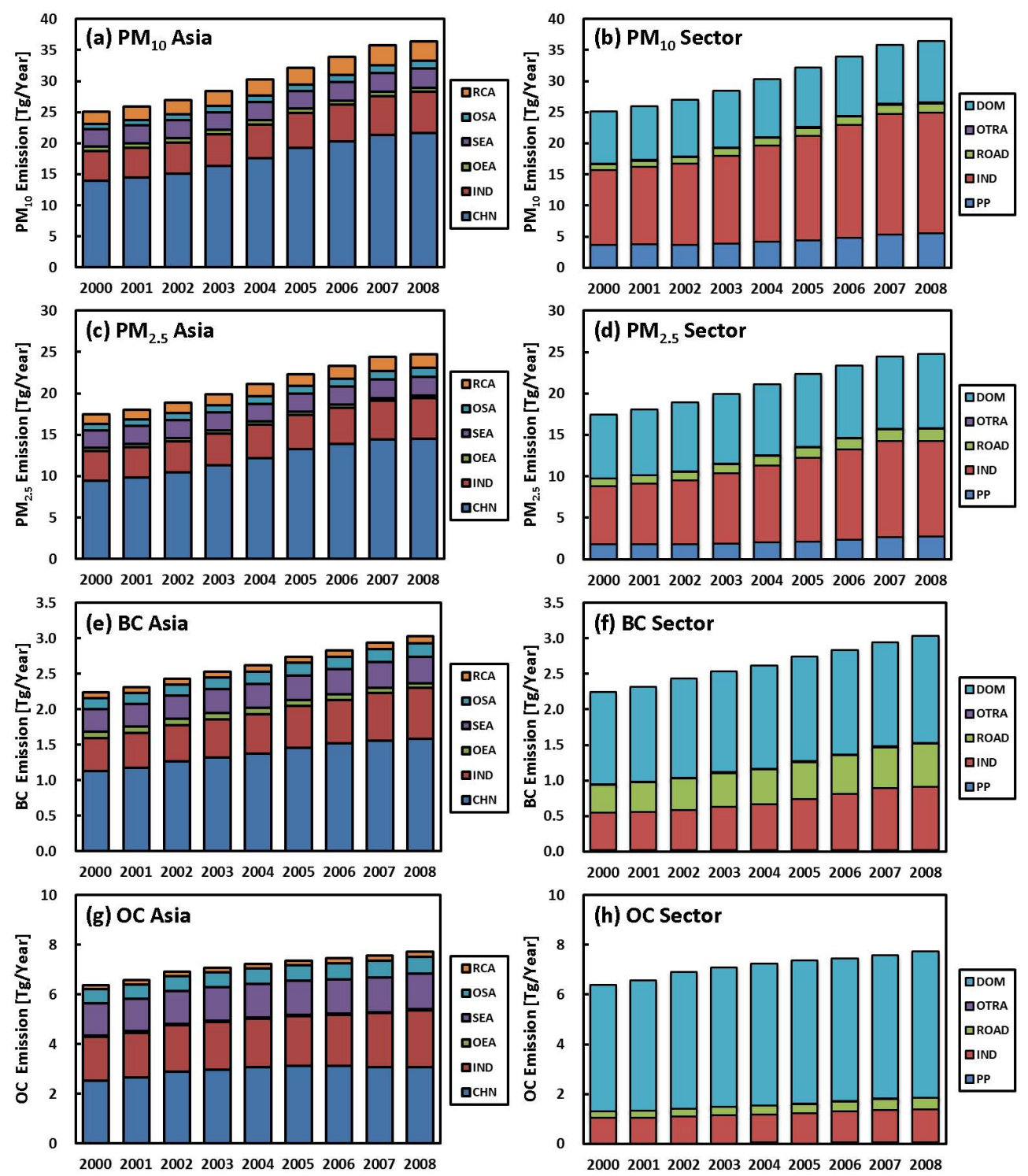

Fig. 5. Annual emissions of aerosols $\left(\mathrm{PM}_{10}, \mathrm{PM}_{2.5}\right.$, BC, and $\mathrm{OC}$ ) in Asia from 2000 to 2008 for each region (left panels) and sector (right panels). Abbreviations are the same as in Fig. 4.

China and India showed similar trends. In India, emissions from power plants increased steadily from 2000 to 2008, thus, the growth rate of total $\mathrm{SO}_{2}$ emissions from 2000 to 2008 was slightly larger for India than for China, although the absolute amounts were much larger for China. In SEA, $\mathrm{SO}_{2}$ emissions have increased recently, although its contribution to the Asian total has been small compared to China and India. The largest contributor of $\mathrm{SO}_{2}$ emissions in SEA was Indonesia (43\% in 2008) followed by Thailand (16\% in 2008). In OSA the majority of emissions were from Pakistan ( $80 \%$ in 2008). The contribution from RCA to the Asian total was relatively large for $\mathrm{SO}_{2}$ emissions because of the output from large plants producing non-ferrous metals, such as copper and zinc, in Ural and Eastern Siberia (especially
Norilsk). For Japan, South Korea, and Taiwan, total $\mathrm{SO}_{2}$ emissions decreased from 2000 to 2008, by $12 \%, 15 \%$, and $35 \%$, respectively. In Japan, emissions from the industrial sector increased slightly from 2000 to 2004 and decreased rapidly after 2005. Emissions from power plants increased but those from other sectors decreased slightly between 2000 and 2008. In South Korea, emissions from power plants and road transport decreased rapidly late in the target period, but emissions from the industrial sector increased slightly. Ship emissions in South Korea increased gradually. In Taiwan, emissions from power plants and industry decreased almost monotonically, whereas from other sources were almost constant from 2000 to 2008. 

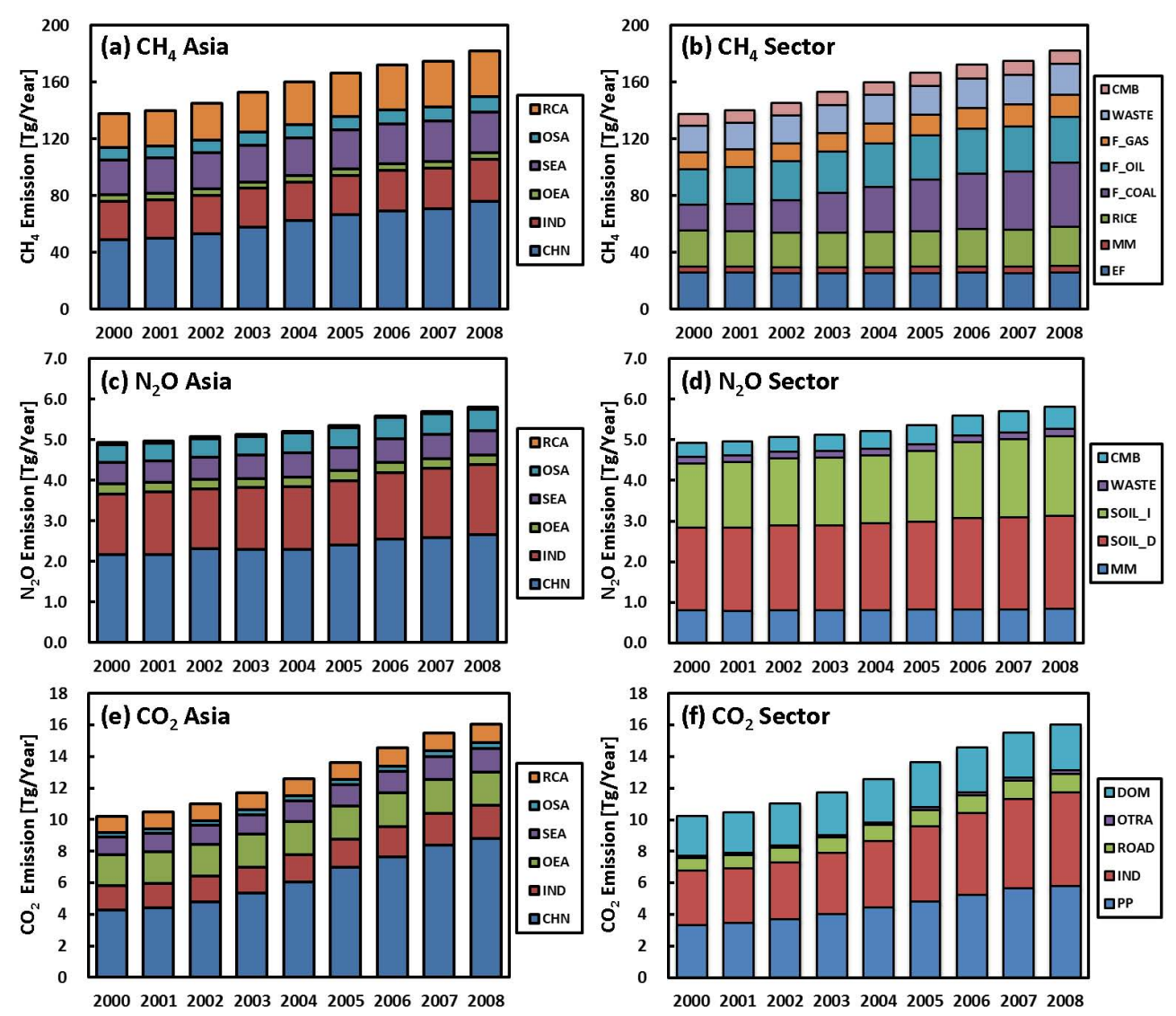

Fig. 6. Annual emissions of greenhouse gases $\left(\mathrm{CH}_{4}, \mathrm{~N}_{2} \mathrm{O}\right.$, and $\left.\mathrm{CO}_{2}\right)$ in Asia from 2000 to 2008 for each region (left panels) and sector (right panels). Abbreviations are the same as Fig. 4, plus $\mathrm{EF}=$ Enteric fermentation, RICE $=$ Rice cultivation, F_COAL/F_OIL/F_GAS $=$ Fugitive emissions related to coal/oil/gas, SOIL_D = Direct soil emissions, and SOIL_I = Indirect soil emissions.

\subsection{2 $\mathrm{NO}_{\mathrm{x}}$}

Total $\mathrm{NO}_{\mathrm{x}}$ emissions as $\mathrm{NO}_{2}$ in 2008 (growth rate between 2000 and 2008) in REAS 2.1 are $53.9 \mathrm{Tg}(+54 \%)$ for Asia, $27.0 \mathrm{Tg}(+89 \%)$ for China, $11.1 \mathrm{Tg}(+56 \%)$ for India, $4.1 \mathrm{Tg}$ $(-14 \%)$ for OEA, $5.5 \mathrm{Tg}(+56 \%)$ for SEA, $2.1 \mathrm{Tg}(+30 \%)$ for OSA, and $4.1 \mathrm{Tg}(+14 \%)$ for RCA. The largest contributors were China (41-50\% during the period 2000-2008) and India (about $20 \%$ during the period 2000-2008). China's share of the Asian total was smaller for $\mathrm{NO}_{\mathrm{x}}$ than for $\mathrm{SO}_{2}$, but the ratios increased monotonically from 2000 to 2008 . India's share of the Asian total was almost constant, but its emissions increased by $56 \%$ from 2000 to 2008 .

Year-to-year growth rates of Chinese $\mathrm{NO}_{\mathrm{x}}$ emissions increased rapidly after 2002 but decreased slightly after 2005 . One reason was the installation of low- $\mathrm{NO}_{\mathrm{x}}$ boilers especially in new large power plants (Zhang et al., 2007). Thus, the growth rates of $\mathrm{NO}_{\mathrm{x}}$ emissions from 2000 to 2008 $(130 \%)$ in the power plant sector were smaller than those of $\mathrm{CO}_{2}(149 \%)$. Again, this effect was pronounced in Inner Mongolia, although the effects of low- $\mathrm{NO}_{\mathrm{x}}$ boilers were much smaller than the effects of FGD on $\mathrm{SO}_{2}$. Another rea- son is the implementation of new vehicle emission standards (Zhang et al., 2009a). Industrial emissions of $\mathrm{NO}_{\mathrm{x}}$ in China increased rapidly rising to double the emissions in the road transport sector by 2008 , although the two sectors were roughly equal in 2000 .

In India, road transport emissions were the largest contributor to $\mathrm{NO}_{\mathrm{x}}$ emissions ( $32 \%$ in 2000 and $42 \%$ in 2008) and doubled from 2000 to 2008 . The contribution of power plants was almost constant (about $28 \%$ ). In SEA, rapid increases after 2005 were mainly due to road transport emissions in Indonesia, a reflection of the increased number of cars, buses, and trucks. In 2008, about half of Southeast Asian $\mathrm{NO}_{\mathrm{x}}$ emissions were from Indonesia, $15 \%$ from Thailand, and $11 \%$ from Malaysia. Emissions in Pakistan increased until 2005, then remained almost constant from 2006 to 2008, the total growth rate being about $50 \%$ from 2000 to 2008 . Contributions to $\mathrm{NO}_{\mathrm{x}}$ emissions in RCA were 66-70\% from Asian Russia and 14-19\% from Kazakhstan during the period. Total emissions increased slightly due to growth in the road transport sector. Total $\mathrm{NO}_{\mathrm{x}}$ emissions in Japan, South Korea, and Taiwan decreased from 2000 to 2008, as did $\mathrm{SO}_{2}$ emissions. In Japan, $\mathrm{NO}_{\mathrm{x}}$ emissions were almost constant 
Table 6. Summary of national emissions in 2008 for each species and total annual emissions in Asia from 2000 to 2008 (Gg $\mathrm{yr}^{-1}$ ). $\mathrm{Ratios}$ of total Asian emissions between 2008 and 2000 are also presented.

\begin{tabular}{|c|c|c|c|c|c|c|c|c|c|c|c|c|}
\hline Country & $\mathrm{SO}_{2}$ & $\mathrm{NO}_{\mathrm{x}}^{\mathrm{a}}$ & $\mathrm{CO}$ & NMVOC & $\mathrm{PM}_{10}$ & $\mathrm{PM}_{2.5}$ & $\mathrm{BC}$ & $\mathrm{OC}$ & $\mathrm{NH}_{3}$ & $\mathrm{CH}_{4}$ & $\mathrm{~N}_{2} \mathrm{O}$ & $\mathrm{CO}_{2}^{\mathrm{b}}$ \\
\hline China & 33457 & 26969 & 201967 & 27098 & 21606 & 14514 & 1589 & 3081 & 14844 & 75975 & 2661 & 8814 \\
\hline Japan & 761 & 2207 & 5029 & 1317 & 130 & 94 & 26 & 10 & 483 & 1992 & 81 & 1192 \\
\hline Korea, Rep of & 417 & 1059 & 690 & 857 & 110 & 56 & 13 & 9 & 190 & 1171 & 82 & 532 \\
\hline Korea, DPR & 226 & 288 & 5137 & 158 & 291 & 128 & 15 & 18 & 106 & 664 & 19 & 78 \\
\hline Mongolia & 73 & 136 & 661 & 46 & 78 & 33 & 1 & 2 & 120 & 465 & 36 & 12 \\
\hline Taiwan & 128 & 442 & 740 & 687 & 86 & 54 & 11 & 6 & 160 & 385 & 29 & 271 \\
\hline Brunei & 11 & 11 & 6 & 31 & 1 & 1 & 0 & 0 & 8 & 544 & 2 & 8 \\
\hline Cambodia & 31 & 73 & 1007 & 207 & 58 & 55 & 11 & 43 & 126 & 768 & 22 & 17 \\
\hline Indonesia & 1808 & 2817 & 22499 & 7316 & 1327 & 997 & 179 & 682 & 1743 & 11398 & 219 & 573 \\
\hline Laos & 140 & 61 & 386 & 82 & 24 & 22 & 4 & 16 & 84 & 353 & 12 & 6 \\
\hline Malaysia & 357 & 619 & 3454 & 1680 & 210 & 132 & 15 & 34 & 238 & 2733 & 49 & 206 \\
\hline Myanmar & 54 & 196 & 2651 & 724 & 160 & 152 & 31 & 123 & 421 & 3146 & 65 & 48 \\
\hline Philippines & 436 & 349 & 2286 & 842 & 169 & 114 & 14 & 68 & 415 & 1708 & 66 & 103 \\
\hline Singapore & 177 & 114 & 156 & 310 & 7 & 5 & 1 & 1 & 11 & 66 & 3 & 40 \\
\hline Thailand & 678 & 851 & 8208 & 2144 & 483 & 267 & 33 & 142 & 580 & 4347 & 92 & 280 \\
\hline Vietnam & 520 & 458 & 7671 & 1660 & 650 & 520 & 83 & 312 & 572 & 3909 & 68 & 206 \\
\hline Bangladesh & 126 & 434 & 2444 & 758 & 313 & 218 & 32 & 117 & 936 & 3957 & 111 & 76 \\
\hline Bhutan & 4 & 18 & 283 & 46 & 23 & 19 & 3 & 13 & 43 & 141 & 11 & 4 \\
\hline India & 10077 & 11061 & 61803 & 15946 & 6651 & 4884 & 713 & 2286 & 9421 & 29431 & 1721 & 2103 \\
\hline Nepal & 30 & 104 & 2080 & 425 & 146 & 135 & 26 & 102 & 245 & 852 & 42 & 33 \\
\hline Pakistan & 1133 & 1160 & 8596 & 1978 & 570 & 529 & 108 & 374 & 1595 & 4925 & 301 & 245 \\
\hline Sri Lanka & 111 & 141 & 1313 & 372 & 138 & 106 & 16 & 59 & 125 & 376 & 14 & 29 \\
\hline Afghanistan & 3 & 207 & 387 & 122 & 18 & 17 & 7 & 9 & 137 & 368 & 45 & 2 \\
\hline Maldives & 3 & 10 & 146 & 8 & 0 & 0 & 0 & 0 & 0 & 3 & 0 & 2 \\
\hline Far East ${ }^{\mathrm{c}}$ & 349 & 633 & 2599 & 298 & 228 & 122 & 19 & 23 & 19 & 627 & 4 & 109 \\
\hline East Siberia $^{c}$ & 1600 & 671 & 2782 & 387 & 385 & 204 & 12 & 19 & 23 & 1441 & 5 & 170 \\
\hline West Siberia $^{\mathrm{c}}$ & 639 & 965 & 5920 & 1284 & 479 & 274 & 29 & 50 & 41 & 19697 & 10 & 310 \\
\hline $\mathrm{Ural}^{\mathrm{b}}$ & 1492 & 432 & 4011 & 586 & 1088 & 618 & 18 & 73 & 22 & 3682 & 5 & 172 \\
\hline Kazakhstan & 1409 & 756 & 2885 & 522 & 439 & 220 & 12 & 28 & 41 & 3980 & 8 & 208 \\
\hline Kyrgyzstan & 34 & 50 & 300 & 41 & 69 & 31 & 2 & 3 & 13 & 77 & 1 & 7 \\
\hline Tajikistan & 15 & 36 & 194 & 29 & 24 & 14 & 1 & 1 & 15 & 82 & 1 & 4 \\
\hline Turkmenistan & 57 & 248 & 371 & 232 & 60 & 28 & 2 & 3 & 14 & 1470 & 5 & 48 \\
\hline Uzbekistan & 560 & 300 & 860 & 307 & 374 & 165 & 3 & 11 & 55 & 1491 & 10 & 128 \\
\hline Asia $^{\mathrm{d}} 2000$ & 42315 & 34915 & 267431 & 46787 & 25088 & 17445 & 2240 & 6385 & 28013 & 137694 & 4928 & 10226 \\
\hline $\operatorname{Asia}^{\mathrm{d}} 2001$ & 43193 & 35922 & 270518 & 48412 & 25904 & 18059 & 2311 & 6571 & 28246 & 140022 & 4964 & 10476 \\
\hline Asia $^{\mathrm{d}} 2002$ & 45361 & 37463 & 279525 & 50537 & 26925 & 18886 & 2433 & 6908 & 29263 & 145159 & 5074 & 11001 \\
\hline Asia $^{\mathrm{d}} 2003$ & 48123 & 39933 & 291557 & 53370 & 28423 & 19905 & 2533 & 7075 & 29455 & 152874 & 5124 & 11708 \\
\hline Asia $^{\mathrm{d}} 2004$ & 51973 & 42944 & 305790 & 57090 & 30305 & 21113 & 2618 & 7238 & 29686 & 159960 & 5207 & 12582 \\
\hline Asia $^{\mathrm{d}} 2005$ & 56862 & 46124 & 327213 & 59889 & 32174 & 22337 & 2740 & 7369 & 30410 & 166577 & 5351 & 13626 \\
\hline Asia $^{\mathrm{d}} 2006$ & 58659 & 48795 & 335547 & 63310 & 33923 & 23350 & 2832 & 7457 & 31649 & 172087 & 5595 & 14546 \\
\hline Asia $^{\mathrm{d}} 2007$ & 58285 & 51833 & 347743 & 66710 & 35819 & 24446 & 2942 & 7573 & 32340 & 174669 & 5699 & 15501 \\
\hline Asia $^{\mathrm{d}} 2008$ & 56913 & 53875 & 359525 & 68501 & 36397 & 24729 & 3029 & 7719 & 32843 & 182224 & 5804 & 16036 \\
\hline Asia $^{\mathrm{d}}$ 2008/2000 & 1.34 & 1.54 & 1.34 & 1.46 & 1.45 & 1.42 & 1.35 & 1.21 & 1.17 & 1.32 & 1.18 & 1.57 \\
\hline
\end{tabular}

${ }^{\mathrm{a}} \mathrm{Gg}-\mathrm{NO}_{2} \mathrm{yr}^{-1}$.

b $\operatorname{Tg~yr}^{-1}$.

c Asian Russia.

${ }^{\mathrm{d}}$ Asia in this table include all target countries and sub-regions in REAS 2.1.

from 2000 to 2004 and decreased after 2005 as road transport emissions fell. Taiwan showed a similar pattern, although there were year-to-year variations between 2000 and 2003.
Emissions in South Korea increased from 2000 to 2004 but then decreased due to reduced emissions from power plants.

In addition to fuel combustion, soil is an important source of $\mathrm{NO}_{\mathrm{x}}$ emissions in Asia. The proportion of emissions from 
Table 7. Proportion of total Asian emissions from sub-regions of Asia (\% 2000/2008).

\begin{tabular}{lllllll}
\hline & $\mathrm{SO}_{2}$ & $\mathrm{NO}_{\mathrm{x}}$ & $\mathrm{CO}$ & $\mathrm{NMVOC}$ & $\mathrm{PM}_{10}$ & $\mathrm{PM}_{2.5}$ \\
\hline China & $54.3 / 58.8$ & $40.9 / 50.1$ & $53.0 / 56.2$ & $33.8 / 39.6$ & $55.9 / 59.4$ & $54.3 / 58.7$ \\
India & $15.5 / 17.7$ & $20.3 / 20.5$ & $17.3 / 17.2$ & $24.8 / 23.3$ & $18.8 / 18.3$ & $20.3 / 19.8$ \\
East Asia except for China & $4.3 / 2.8$ & $13.7 / 7.7$ & $5.4 / 3.4$ & $7.9 / 4.5$ & $2.8 / 1.9$ & $2.3 / 1.5$ \\
Southeast Asia & $8.8 / 7.4$ & $10.2 / 10.3$ & $13.5 / 13.4$ & $21.9 / 21.9$ & $11.1 / 8.5$ & $12.1 / 9.2$ \\
South Asia except for India & $2.8 / 2.5$ & $4.6 / 3.8$ & $4.5 / 4.2$ & $6.1 / 5.4$ & $3.5 / 3.3$ & $4.5 / 4.1$ \\
Asian part of Russia and Central Asia & $14.2 / 10.8$ & $10.3 / 7.6$ & $6.2 / 5.5$ & $5.4 / 5.4$ & $7.9 / 8.6$ & $6.5 / 6.8$ \\
\hline & $\mathrm{BC}$ & $\mathrm{OC}$ & $\mathrm{NH}_{3}$ & $\mathrm{CH}_{4}$ & $\mathrm{~N}_{2} \mathrm{O}$ & $\mathrm{CO}_{2}$ \\
\hline China & $50.7 / 52.5$ & $39.6 / 39.9$ & $44.8 / 45.2$ & $35.4 / 41.7$ & $43.9 / 45.9$ & $41.6 / 55.0$ \\
India & $20.6 / 23.5$ & $27.6 / 29.6$ & $28.8 / 28.7$ & $19.8 / 16.2$ & $30.5 / 29.7$ & $15.1 / 13.1$ \\
East Asia except for China & $4.0 / 2.2$ & $0.8 / 0.6$ & $3.9 / 3.2$ & $3.3 / 2.6$ & $5.1 / 4.3$ & $19.3 / 13.0$ \\
Southeast Asia & $14.1 / 12.3$ & $20.4 / 18.4$ & $12.6 / 12.8$ & $17.9 / 15.9$ & $10.7 / 10.3$ & $10.9 / 9.3$ \\
South Asia except for India & $7.1 / 6.3$ & $8.9 / 8.7$ & $9.1 / 9.4$ & $6.3 / 5.8$ & $8.9 / 9.0$ & $2.9 / 2.4$ \\
Asian part of Russia and Central Asia & $3.5 / 3.2$ & $2.7 / 2.7$ & $0.8 / 0.7$ & $17.2 / 17.9$ & $0.9 / 0.8$ & $10.1 / 7.2$ \\
\hline
\end{tabular}

soil in the annual total during the period was $10-14 \%$ for Asia, 7-11\% for China, 12-18\% for India, 3-4\% for OEA, $10-16 \%$ for SEA, 25-31 \% for OSA, and 23-26\% for RCA. Soil $\mathrm{NO}_{\mathrm{x}}$ emissions have large monthly variations, with a peak in summer. Therefore, their relative importance depends on regions and seasons.

\subsubsection{CO}

Total CO emissions in 2008 (growth rate between 2000 and 2008) in REAS 2.1 were $359.5 \mathrm{Tg}(+34 \%)$ for Asia, $202.0 \mathrm{Tg}(+42 \%)$ for China, $61.8 \mathrm{Tg}(+33 \%)$ for India, $12.3 \mathrm{Tg}(-15 \%)$ for OEA, $48.3 \mathrm{Tg}(+34 \%)$ for SEA, $15.2 \mathrm{Tg}$ $(+26 \%)$ for OSA, and $19.9 \mathrm{Tg}(+20 \%)$ for RCA. The largest contributors were China (53-57\% during the period 20002008) and India (16-18\% during the period 2000-2008) as was the case for $\mathrm{SO}_{2}$ and $\mathrm{NO}_{\mathrm{x}}$. The contribution from SEA was also relatively large (13-14\% during the period 20002008). In 2000, Asian emissions from the domestic sector were the largest (42\%) followed by the industrial and road transport sectors (both $28 \%$ ). The power plants sector was not an important source for $\mathrm{CO}$. Industrial emissions grew faster in Asia than from other sectors and becoming equal to the domestic sector at about $37 \%$ after 2007.

These changes reflect the variation of $\mathrm{CO}$ emissions in China between 2000 and 2008. Industrial emissions in China more than doubled during this period, the increase being related to the production of steel, coke, cement, bricks, and similar commodities. Emissions increased from 2000 to 2006 at a slower rate in the domestic sector than in the industrial sector, but then began to decrease after 2007 as consumption of coal and biofuel for residential use decreased in China. This is one reason why growth rates of emissions in China decreased slightly in the latter part of the period. Other reasons are include the effects of regulations on road vehicle emissions and the substitution of shaft kilns for rotary kilns in cement production plants.

In India, $\mathrm{CO}$ emissions from the domestic, industrial, and road transport sectors increased monotonically between 2000 and 2008. The largest sector was domestic (53-59\% during the period 2000-2008), but contribution rates are decreasing. Growth rates of emissions in road transport sector were increasing and reached nearly $20 \%$ of total emissions in 2008. In SEA, the majority of emissions were from biofuel combustion in the domestic sector, which showed an increasing trend. Furthermore, the growth rate of road transport emissions was much higher, and emission values more than doubled from 2000 to 2008. Indonesia was the largest contributing country $(47 \%)$ in 2008 , followed by Vietnam and Thailand (16-17\%). In OSA, emissions generally increased with $56 \%$ of the total coming from Pakistan, $16 \%$ from Bangladesh, and $14 \%$ from Nepal in 2008. The majority of $\mathrm{CO}$ emissions in OSA were from biofuel combustion. Emissions in RCA were almost constant from 2000 to 2005 and increased after 2006 due to emissions from the road transport sector. Contributions were dominated by Asian Russia (77-82\% during the period 2000-2008) and Kazakhstan (9-14\% during the period 2000-2008). CO emissions from Japan, South Korea, and Taiwan decreased from 2000 to 2008 by $28 \%, 23 \%$, and $34 \%$, respectively. For these countries, emissions were mostly from the road transport sector and their values decreased monotonically from 2000 to 2008 .

\subsubsection{NMVOC}

Total NMVOC emissions in 2008 (growth rate between 2000 and 2008) were $68.5 \mathrm{Tg}(+46 \%)$ for Asia, 27.1 $\mathrm{Tg}(+71 \%)$ for China, $15.9 \mathrm{Tg}(+37 \%)$ for India, $3.1 \mathrm{Tg}(-17 \%)$ for OEA, 15.0 Tg $(+47 \%)$ for SEA, $3.7 \mathrm{Tg}(+29 \%)$ for OSA, and $3.7 \mathrm{Tg}(+45 \%)$ for RCA. During the period 2000-2008, China, India, and SEA contributed 34-40\%, 23-25\%, and 
21-22\% of the Asian total, respectively. In 2000, emissions from the domestic sector were comparable to those from the transport sector (including evaporative emissions) and larger than those from solvent use. However, the growth rates for the road transport and solvent use sectors exceeded those for the domestic sector. By 2008, road transport emissions were the largest source $(34 \%)$, and solvent and paint use (24\%) was almost the same as domestic emissions in the Asia total.

In China, the road transport sector including evaporation was the largest NMVOC source (45\%) in 2000, but growth rates were moderate especially in later years, because of regulations on vehicles. Emissions from solvent use (including paint use) increased rapidly to $38 \%$ in 2008 , exceeding those from road transport (35\%). Emissions in Jiangsu, Guangdong, and Zhejiang provinces were disproportionate to $\mathrm{NO}_{\mathrm{x}}$ emissions because of solvent and paint use. Domestic emissions in China, basically from biofuel combustion increased slightly from 2000 to 2005 but then decreased after 2006.

In India, NMVOC emissions from biofuel combustion increased monotonically and were the largest contributor, but road transport emissions grew faster than other sectors. Thus the percentages contributed by the domestic and road transport sectors were $55 \%$ and $22 \%$ in 2000, but became $43 \%$ and $35 \%$, respectively in 2008. Contributions from solvent and paint use were small in India. Similarly, in SEA both domestic and road transport emissions increased, but road transport grew much faster. The relative importance of road transport emissions increased from $30 \%$ in 2000 to $42 \%$ in 2008 , while of the percentage contributed by the domestic sector decreased from $35 \%$ to $26 \%$. Nearly half of SEA emissions were from Indonesia, whereas $14 \%$ were from Thailand, and $11 \%$ each were from Malaysia and Vietnam. NMVOC emissions in OSA were mostly from biofuel combustion during 2000 and $2008(60-66 \%)$ and generally increased. In RCA, emissions from extraction and handling of oil and gas made up a much larger share of the total in Siberia (36-40\%) than in other regions (about $4 \%$ ). Because of increases in this sector, road transport, and solvent use, the growth rate in NMVOC between 2000 and 2008 was larger than for other species in RCA. In Japan, South Korea, and Taiwan, NMVOC emissions showed different trends. Emissions in Japan decreased almost constantly from 2000 to 2008 by $35 \%$ because of reduced emissions from road transport, usage of paint and solvents. Emissions in South Korea increased slightly, particularly in paint and solvent use. Trends in Taiwan were small overall but mixed across sectors. Road transport emissions increased from 2000 to 2003 but started to decrease after 2004. Emissions from solvent use decreased from 2000 to 2008, and emissions from paint use increased rapidly after 2003.

\subsection{5 $\mathrm{NH}_{3}$}

Total $\mathrm{NH}_{3}$ emissions in 2008 (growth rate between 2000 and 2008) in REAS 2.1 were $32.8 \mathrm{Tg}(+17 \%)$ for Asia, $14.8 \mathrm{Tg}$
$(+18 \%)$ for China, $9.4 \mathrm{Tg}(+17 \%)$ for India, $1.1 \mathrm{Tg}(-2 \%)$ for OEA, $4.2 \mathrm{Tg}(+19 \%)$ for SEA, $3.1 \mathrm{Tg}(+21 \%)$ for OSA, and $0.2 \mathrm{Tg}(+6 \%)$ for RCA. As shown in Fig. $4 \mathrm{j}$, the majority of $\mathrm{NH}_{3}$ emissions in Asia come from agricultural activities (55-58\% from application of fertilizer and about $20 \%$ from manure management). Like other species, Asian $\mathrm{NH}_{3}$ emissions are dominated by China (about $45 \%$ ) and India (about $28 \%$ ). Emissions from South Asia (including India) account for about $38 \%$ of the Asian total. This proportion is larger than it is for other species because of relatively larger contributions from Pakistan and Bangladesh (about $5 \%$ and $3 \%$ in 2008, respectively).

Asian emissions show increasing trends during 2000 and 2008, although the increased amount was relatively small compared to other species. Year-to-year variations were basically controlled by emissions from fertilizer applications. In China, fertilizer-related emissions increased from 2000 to 2002, and decreased in 2003 and 2004, then increased again after 2005. In SEA, emissions related to fertilizer increased rapidly from 2001 to 2004, but varied little in other years.

As described in Sect. 2.2.3, $\mathrm{NH}_{3}$ emissions from agricultural activities were extrapolated from the 2000 data of REAS 1.1 based on the amount of fertilizer usage and numbers of livestock. Therefore, interannual variability of emissions directly reflects the trends in statistics for fertilizer application and livestock. Emissions from latrines made considerable contributions to total emissions (about 13\%). They were the largest contributor (about $46 \%$ ) in RCA because emissions related to agricultural activities were smaller (about $29 \%$ ) than in other regions. Contributions from human perspiration and respiration were small for all regions (about $3 \%$ in Asia). Emissions in Japan, South Korea, and Taiwan were also predominantly from agricultural activities, as in other Asian countries. Emissions in Japan decreased from 2000 to 2008 by $10 \%$. Emissions in Taiwan increased almost monotonically, growing by $18 \%$ from 2000 to 2008 . Emissions of South Korea in 2000 and 2008 were almost the same although there were relatively large year-to-year variations. Trends of $\mathrm{NH}_{3}$ emissions in these countries mainly reflected fertilizer applications.

\subsubsection{Primary aerosol emissions}

This sub-section presents the results for $\mathrm{PM}_{10}, \mathrm{PM}_{2.5}$, $\mathrm{BC}$, and OC. $\mathrm{PM}_{10}$ and $\mathrm{PM}_{2.5}$ showed similar trends and contributions from each region and sector. Total emissions of $\mathrm{PM}_{10} / \mathrm{PM}_{2.5}$ in 2008 (growth rates between 2000 and 2008) in REAS 2.1 were $36.4 / 24.7 \mathrm{Tg}(+45 /+42 \%)$ for Asia, $21.6 / 14.5 \mathrm{Tg}(+54 /+53 \%)$ for China, $6.7 / 4.9 \mathrm{Tg}$ $(+41 /+38 \%)$ for India, $0.7 / 0.4 \mathrm{Tg}(-3 /-9 \%)$ for OEA, $3.1 / 2.3 \mathrm{Tg}(+11 /+7 \%)$ for SEA, $1.2 / 1.0 \mathrm{Tg}(+39 /+29 \%)$ for OSA, and $3.1 / 1.7 \mathrm{Tg}(+58 /+48 \%)$ for RCA. The major sources were the industry and domestic sectors. Both species had smaller emissions from the power plant sector. However, 
the relative contribution from each sector differed in each country.

In China, the industrial sector made the largest contributions to both $\mathrm{PM}_{10}$ and $\mathrm{PM}_{2.5}$. (55-63\% and 46-57\% for $\mathrm{PM}_{10}$ and $\mathrm{PM}_{2.5}$, respectively, for 2000-2008), and those contributions increased by $75 \%$ and $87 \%$, respectively. The proportion of emissions from cement production was large, but decreased from 2000 to 2008 although production of cement increased by a factor of 2.4. As was the case for $\mathrm{CO}$, the shift to rotary kilns led to lower emission factors of $\mathrm{PM}_{10}$ and $\mathrm{PM}_{2.5}$. Emissions from production of steel, coke, and non-ferrous metals increased. Emissions from the domestic sector increased from 2000 to 2005 and then decreased with the reduction in coal and biofuel consumption for residential use in China.

In India and OSA, domestic biofuel combustion accounted for the majority of emissions. In India, power plants ranked second with 27-30\% and 15-17\% for $\mathrm{PM}_{10}$ and $\mathrm{PM}_{2.5}$, respectively. For OSA countries such as Pakistan, industrial emissions increased. For primary aerosol emissions in SEA, the largest contributing country was Indonesia, but Vietnam ranked second (18-21\% and $20-23 \%$ of regional $\mathrm{PM}_{10}$ and $\mathrm{PM}_{2.5}$ emissions, respectively), unlike the case of other species, because of its large consumption of biofuel. In Vietnam, about $60 \%$ of $\mathrm{PM}_{10}$ and $70 \%$ of $\mathrm{PM}_{2.5}$ emissions were from domestic biofuel combustion in 2008. The majority of primary aerosol emissions in Indonesia and Malaysia were from the domestic and industry sectors, respectively. In Thailand, emissions were mainly from the industrial sector, but contributions from power plants were relatively large. In RCA, more than $90 \%$ of $\mathrm{PM}_{10}$ and $\mathrm{PM}_{2.5}$ emissions were from production of iron, steel, and cement.

Mitigation of Short-Lived Climate Force (or Short-Lived Climate Pollutants) is considered to be important for air pollution reduction, climate protection, and sustainable development (Shindell, 2012). Black carbon is one of key species for this category. Black carbon absorbs visible light and contributes to warming of the atmosphere. It also causes health problems and premature death. Organic carbon is considered to have a cooling effect because it reflects incoming sunlight. In addition, $\mathrm{BC}$ and $\mathrm{OC}$ have many common emission sources. Asia is a large source of BC and OC emissions, and therefore, their accurate estimation is fundamentally important.

Total BC emissions in 2008 (growth rate between 2000 and 2008$)$ were $3.03 \mathrm{Tg}(+35 \%)$ for Asia, $1.59 \mathrm{Tg}(+40 \%)$ for China, $0.71 \mathrm{Tg}(+54 \%)$ for India, $0.07 \mathrm{Tg}(-26 \%)$ for OEA, $0.37 \mathrm{Tg}(+18 \%)$ for SEA, $0.19 \mathrm{Tg}(+21 \%)$ for OSA, and $0.10 \mathrm{Tg}(+25 \%)$ for RCA. Compared to their $\mathrm{PM}_{10}$ and $\mathrm{PM}_{2.5}$ emissions, China's contribution of $\mathrm{BC}$ was smaller and India's was slightly larger. Although the ratios of regional contributions of $\mathrm{BC}$ were similar to those for $\mathrm{PM}_{2.5}$, the mix of contributions from different sectors was different. More than half of $\mathrm{BC}$ emissions were from the domestic sector, and the shares of domestic and road transport emissions were larger for $\mathrm{BC}$ than for $\mathrm{PM}_{2.5}$. All countries showed similar tendencies.

In China, more than half of total $\mathrm{BC}$ emissions were from the domestic sector in 2000, but industrial and domestic emissions reached parity in 2008 (about 45\%). The road transport sector accounted for a larger share of the emissions of $\mathrm{BC}$ than of $\mathrm{PM}_{2.5}$ but a smaller share than the domestic and industrial sectors (about $11 \%$ ). In India, the majority of emissions were from domestic biofuel combustion, but road transport emissions grew rapidly, increasing their share from $23 \%$ in 2000 to $34 \%$ in 2008. Pakistan was similar to India although its domestic sector was larger, and the growth rate of its road transport emissions was smaller than India's. Domestic biofuel combustion dominated emissions in Indonesia and Vietnam. In Thailand and Malaysia, more than half of emissions were from the road transport sector. More than $60 \%$ of emissions in RCA were from road transport, and the remainder was mostly from the industrial sector. In RCA, the domestic sector contributed less than $10 \%$, a relatively small share, because biofuel consumption was small.

Total OC emissions in 2008 (growth rate between 2000 and 2008) were $7.72 \mathrm{Tg}(+21 \%)$ for Asia, 3.08 Tg (+22\%) for China, $2.29 \mathrm{Tg}(+30 \%)$ for India, $0.05 \mathrm{Tg}(-14 \%)$ for OEA, $1.42 \mathrm{Tg}(+9 \%)$ for SEA, $0.67 \mathrm{Tg}(+19 \%)$ for OSA, and $0.21 \mathrm{Tg}(+24 \%)$ for RCA. OC emissions differed from other primary aerosols. Emissions in the domestic sector from biofuel combustion dominated the Asian total. Countries with large emissions such as China, India, Indonesia, and Vietnam showed similar features. In Thailand and Malaysia, which had smaller biofuel consumption, the majority of emissions were from industry (Thailand) or industry plus road transport (Malaysia). In RCA, the industrial sector dominated total emissions.

As described in Sect. 2.5, emissions of BC and OC from Taiwan were estimated from $\mathrm{PM}_{2.5}$ and those of $\mathrm{PM}_{2.5}, \mathrm{BC}$, and OC from Japan and South Korea were estimated from $\mathrm{PM}_{10}$. In Japan, primary aerosol emissions decreased almost constantly and by large amounts $(29 \%, 32 \%, 45 \%$, and $39 \%$ for $\mathrm{PM}_{10}, \mathrm{PM}_{2.5}, \mathrm{BC}$, and $\mathrm{OC}$, respectively, from 2000 to 2008) in response to trends in road transport emissions. The industrial and domestic sectors made considerable contributions to $\mathrm{PM}_{10}$ and $\mathrm{PM}_{2.5}$ emissions, but their interannual variation was small. In South Korea, $\mathrm{PM}_{10}$ emissions were almost constant from 2000 to 2006 but then increased very rapidly because of industrial emissions; 2007 and 2008 totals were about $50 \%$ and $70 \%$ greater than 2006, respectively. Trends for $\mathrm{PM}_{2.5}$ were similar. Most $\mathrm{BC}$ and $\mathrm{OC}$ emissions were from the road transport sector, which increased from 2000 to 2004 but decreased rapidly after 2004. Total emissions were slightly smaller in 2008 than in 2000. In Taiwan, the majority of emissions of $\mathrm{PM}_{10}$ and $\mathrm{PM}_{2.5}$ were from the industrial sector, which increased from 2000 to 2003 and then decreased rapidly. However, road transport emissions showed almost opposite tendencies, and as a result total emissions decreased slightly from 2000 to 2008 . BC and OC 
showed similar patterns, but the majority of emissions were from road transport and their trends were weaker than those of $\mathrm{PM}_{10}$ and $\mathrm{PM}_{2.5}$.

\subsubsection{Greenhouse gases $\left(\mathrm{CH}_{4}, \mathrm{~N}_{2} \mathrm{O}\right.$, and $\left.\mathrm{CO}_{2}\right)$}

Total $\mathrm{CH}_{4}$ emissions in 2008 (growth rate between 2000 and 2008) in REAS 2.1 were $182.2 \mathrm{Tg}(+32 \%)$ for Asia, 76.0 Tg (+56\%) for China, $29.4 \mathrm{Tg}(+8 \%)$ for India, $4.7 \mathrm{Tg}$ $(+3 \%)$ for OEA, $29.0 \mathrm{Tg}(+18 \%)$ for SEA, $10.6 \mathrm{Tg}(+22 \%)$ for OSA, and $32.5 \mathrm{Tg}(+37 \%)$ for RCA. China (35-42\%) and India (16-20\%) were the two largest contributors; however, contributions from SEA (16-18\%) and RCA (17-19\%) were also relatively large. Fugitive emissions from fossil fuels and agricultural emissions were the major sources for Asia as a whole. In China, emissions increased rapidly, and the largest contributions were from coal mining, most of which is underground mining where the $\mathrm{CH}_{4}$ emission factor is large (IPCC, 2006). Mitigation of these emissions is considered to be an important measure to reduce Short-Lived Climate Forcers (Shindell, 2012). Emissions of $\mathrm{CH}_{4}$ from coal mining in India were estimated to be small, although coal production is large. This is because we assumed that most coal production in India was by surface mining for which the emission factor for $\mathrm{CH}_{4}$ is small (IPCC, 2006). More than $85 \%$ of total emissions in RCA were from fugitive emissions from oil and gas activities especially in Western Siberia, Ural, and Kazakhstan. We estimated relatively large contributions (about $36 \%$ ) from fugitive emissions from fossil fuels in SEA. In SEA and South Asia (including India), the majority of emissions were from agricultural activities. In India, enteric fermentation and rice cultivation contributed $35-38 \%$ and $21-25 \%$, respectively, emissions from 2000 to 2008. Tendencies in OSA were similar. Agricultural emissions in SEA were about $47 \%$ of total emissions, a slightly smaller share than in South Asia due to the relatively large contributions from fugitive emissions. In Japan, South Korea, and Taiwan, the majority of $\mathrm{CH}_{4}$ emissions in 2008 were from solid waste disposal and waste water treatment: about $48 \%$ for Japan, about $44 \%$ for South Korea, and about $65 \%$ for Taiwan. Interannual variation of total $\mathrm{CH}_{4}$ emissions in these countries was relatively small. In other Asian countries, the share of $\mathrm{CH}_{4}$ emissions from waste treatments was about $13-15 \%$ between 2000 and 2008, except for RCA where it was much smaller.

Total $\mathrm{N}_{2} \mathrm{O}$ emissions in 2008 (growth rate between 2000 and 2008) in REAS 2.1 were $5.80 \mathrm{Tg}(+18 \%)$ for Asia, $2.66 \mathrm{Tg}(+23 \%)$ for China, $1.72 \mathrm{Tg}(+14 \%)$ for India, $0.25 \mathrm{Tg}(-2 \%)$ for OEA, $0.60 \mathrm{Tg}(+13 \%)$ for SEA, $0.52 \mathrm{Tg}$ $(+20 \%)$ for OSA, and $0.05 \mathrm{Tg}(+20 \%)$ for RCA. Agricultural emissions, specifically direct and indirect soil and manure management sources, dominated $\mathrm{N}_{2} \mathrm{O}$ emissions in Asia from 2000 to 2008: about $41 \%$ from direct soil, about $33 \%$ from indirect soil, and about $15 \%$ from manure management. China made up about $45 \%$ and India about $30 \%$ of Asian emissions. India had a large share for this species than others. Japan and South Korea had larger proportions from industrial processes and road transport than other regions, although agricultural emissions were also large. In RCA, the contribution of agricultural emissions was exceptionally small (about $21 \%$ ), and emissions from fuel combustion sources were relatively large compared to other regions.

$\mathrm{CO}_{2}$ emissions generally are a direct reflection of energy consumption, infrastructure buildup, and economic growth. REAS 2.1 includes emissions from combustion of fossil fuels and biofuels and emissions from industrial processes mainly cement production. Total $\mathrm{CO}_{2}$ emissions in 2008 (growth rate between 2000 and 2008) in REAS 2.1 were $16.0 \mathrm{Pg}$ $(+57 \%)$ for Asia, $8.8 \mathrm{Pg}(+107 \%)$ for China, $2.1 \mathrm{Pg}(+36 \%)$ for India, $2.1 \mathrm{Pg}(+6 \%)$ for OEA, $1.5 \mathrm{Pg}(+33 \%)$ for SEA, $0.4 \mathrm{Pg}(+33 \%)$ for OSA, and $1.2 \mathrm{Pg}(+12 \%)$ for RCA. The growth of $\mathrm{CO}_{2}$ emissions in China was extremely high during 2000 and 2008, and its share of the Asia total increased from $42 \%$ in 2000 to $55 \%$ in 2008 , although most other Asian countries also increased $\mathrm{CO}_{2}$ emissions. Nearly $55 \%$ of Chinese emissions were from coal combustion and its proportion increased from 2000 to 2008. Biofuel combustion went from about $13 \%$ in 2000 to about $7 \%$ in 2008 , while industrial process emissions remained about $10 \%$. Other regions (except RCA) had larger relative contributions from biofuel combustion than China. Biofuel accounted for 27$33 \%$ in India, $25-30 \%$ in SEA, and $45-52 \%$ in SA outside India from 2000 to 2008 . The, largest contributor was coal combustion in India (39-46\%) and gas and oil combustion in SEA (46-51\%). In RCA, emissions from gas and coal combustion were $39-43 \%$ and $39-42 \%$ of total $\mathrm{CO}_{2}$ emissions, respectively. In Japan, total $\mathrm{CO}_{2}$ emissions increased very little between 2000 and 2008, pattern consistent with its recent economic situation. Emissions in South Korea and Taiwan increased gradually about $19 \%$ and $18 \%$, respectively, between 2000 and 2008. Emissions from power plants in these three countries increased almost monotonically except for Japan and Taiwan in 2008, probably because of the economic downturn precipitated by the Lehman Brothers bankruptcy.

\subsection{Spatial distribution}

Figure 7 shows the spatial distributions of annual emissions of $\mathrm{SO}_{2}, \mathrm{NO}_{\mathrm{x}}, \mathrm{CO}, \mathrm{NMVOC}, \mathrm{PM}_{10}, \mathrm{PM}_{2.5}, \mathrm{BC}, \mathrm{OC}, \mathrm{NH}_{3}$, $\mathrm{CH}_{4}, \mathrm{~N}_{2} \mathrm{O}$, and $\mathrm{CO}_{2}$ in 2000 and 2008 at $0.25^{\circ} \times 0.25^{\circ}$ resolution. The areas of highest emissions were in China and India for all species, especially in eastern China, Chongqing, Sichuan province, the Indo-Gangetic Plain, and southern India. These areas have large populations and significant economic and industrial activity. $\mathrm{NH}_{3}, \mathrm{CH}_{4}$, and $\mathrm{N}_{2} \mathrm{O}$, emissions were distributed over rural areas of intensive agricultural activity such as southern China and India. High $\mathrm{CH}_{4}$ emissions also occurred over Ural, Western Siberia, and SEA because of the large fugitive emissions from gas- and oil-related activities. 

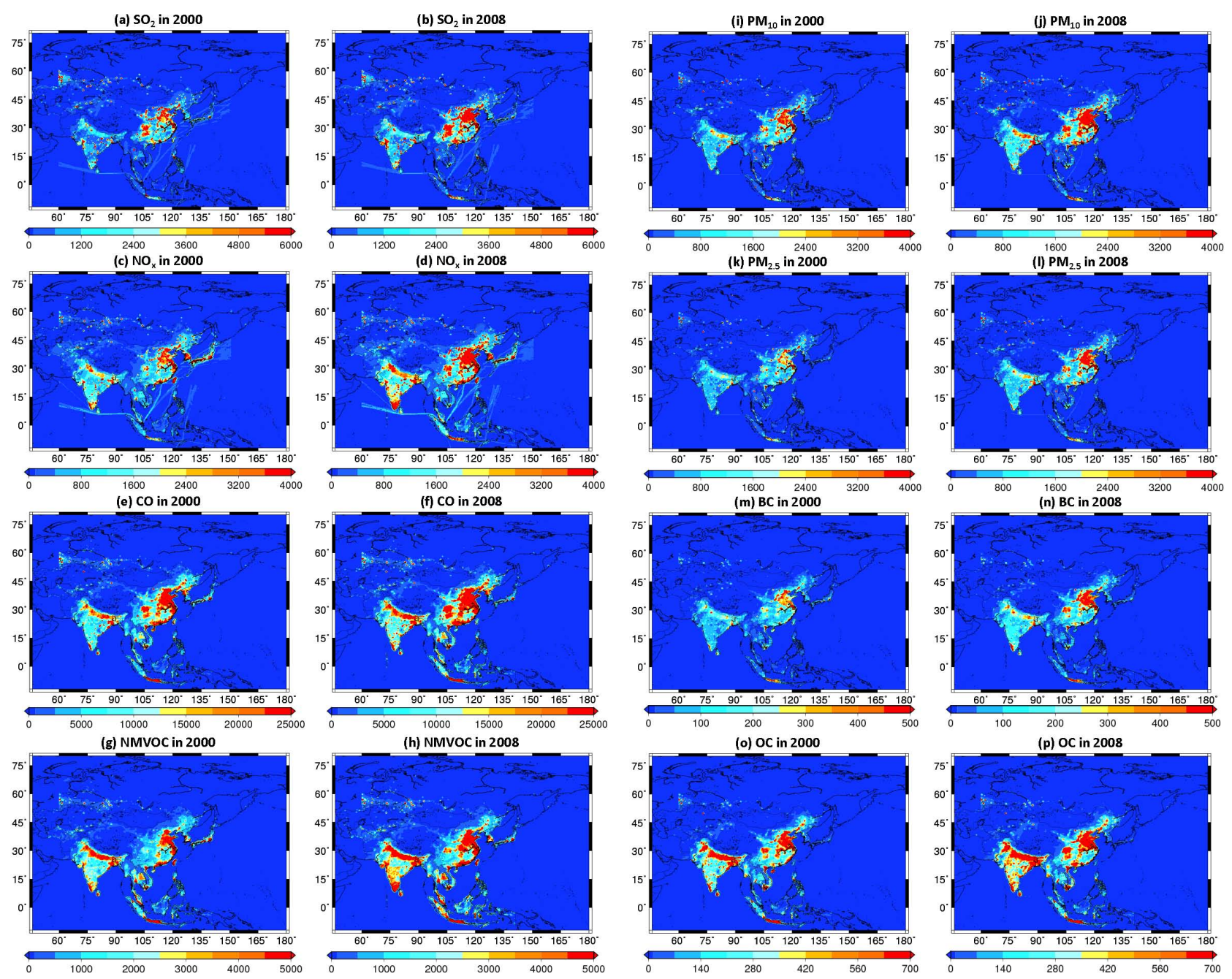

Fig. 7. Spatial distributions of annual emissions ( $\mathrm{Mg} \mathrm{yr}^{-1}$ per grid cell) of $\mathrm{SO}_{2}, \mathrm{NO}_{\mathrm{x}}, \mathrm{CO}, \mathrm{NMVOC} \mathrm{PM}_{10}, \mathrm{PM}_{2.5}, \mathrm{BC}, \mathrm{OC}, \mathrm{NH}_{3}, \mathrm{CH}_{4}$, $\mathrm{N}_{2} \mathrm{O}$, and $\mathrm{CO}_{2}$ in 2000 and 2008 .

\subsection{Monthly variation}

Figure 8 presents the distributions of monthly $\mathrm{SO}_{2}, \mathrm{NO}_{\mathrm{x}}$ and BC emissions in July and December 2008 for all of Asia. Monthly fractions for each sector and 2000-2008 trends for anthropogenic emissions of $\mathrm{SO}_{2}, \mathrm{NO}_{\mathrm{x}}$ (excluding soil emissions) and $\mathrm{BC}$ are shown in Fig. 9 for China and Fig. 10 for India.

For China, emissions from the power plant and industrial sectors generally increased throughout the year, in keeping with the general trend from 2000 to 2008 (Fig. 9). In the power plant sector, small peaks during summer months probably reflect power generation for air conditioning. Small dips in February in both sectors appear to reflect the reduction of economic activity during the Chinese Spring Festival. The majority of $\mathrm{SO}_{2}$ and $\mathrm{NO}_{\mathrm{x}}$ emissions in China were from the power plant and industrial sectors, which exerted the predominant influence on monthly variation of total emis- sions. Note that emissions from power plants and industry decreased after the summer of 2008, probably because of the Lehman Brothers bankruptcy. Emissions from the domestic sector in China showed peaks during winter months because fuel consumption for residential heating was estimated on the basis of monthly surface temperature, as described in Sect. 2.2.5. These tendencies are especially evident in BC emission maps (Fig. 8e, f) in higher-latitude area. Winter peaks of smaller amplitude were also evident in $\mathrm{NO}_{\mathrm{x}}$ and $\mathrm{BC}$ emissions in the road transport sector because of cold start emissions.

In India, emissions from the power plant and industrial sectors were lower during the summer and higher in winter, except for a dip in January (Fig. 10). These two sectors therefore govern the monthly variations of total $\mathrm{SO}_{2}$ and $\mathrm{NO}_{\mathrm{x}}$ emissions. As in China, monthly variations of total $\mathrm{BC}$ emissions reflected emissions from the domestic sector, emissions from which were larger in winter and lower in summer. In 

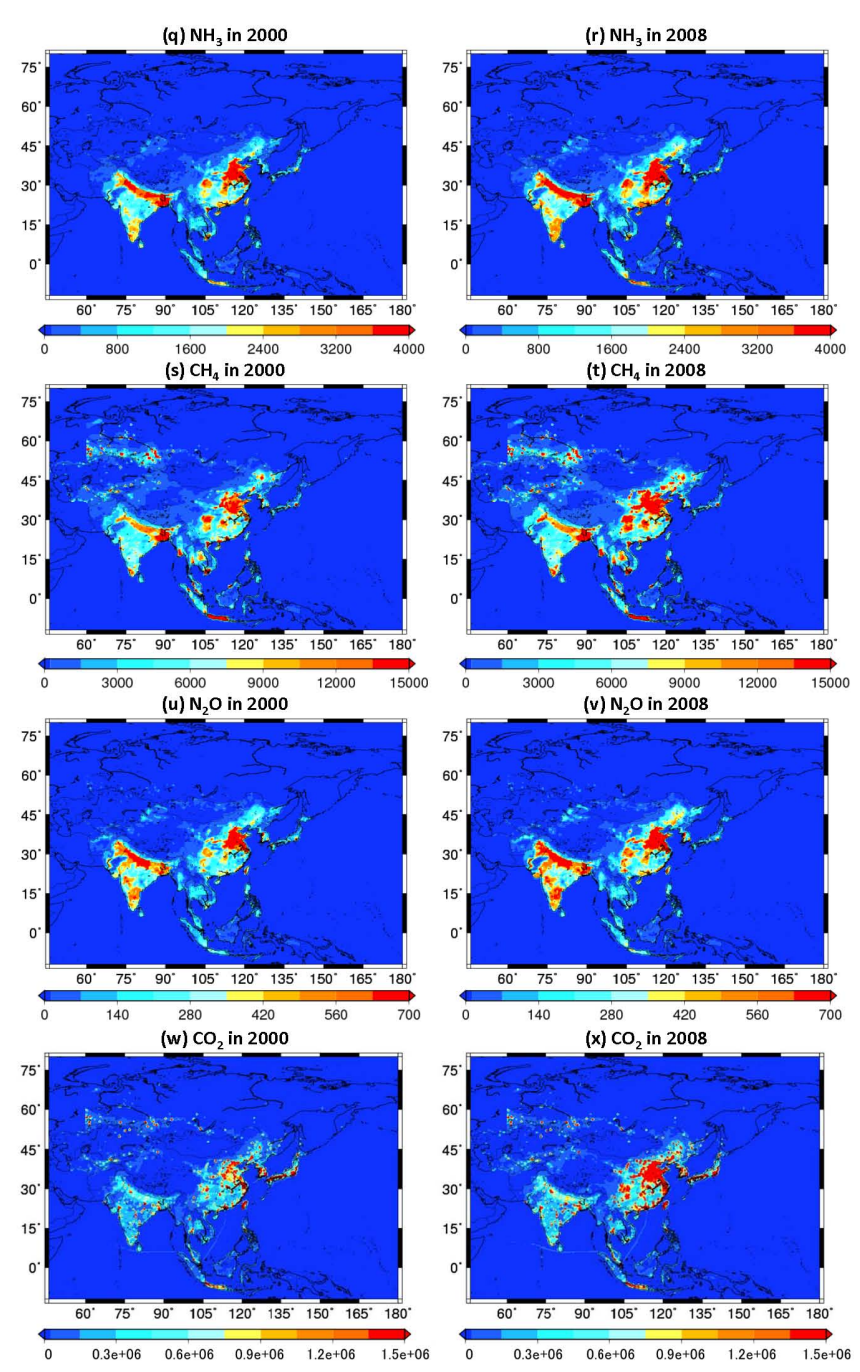

Fig. 7. Continued.

India, cold start emissions from road vehicles also added to the total BC emissions in winter. However, because winter temperatures are generally warmer in India than in China, the amplitude of these effects was much smaller.

Figure 11 presents the regional trends of monthly anthropogenic emissions of $\mathrm{SO}_{2}, \mathrm{NO}_{\mathrm{x}}$, and $\mathrm{BC}$ between 2000 and 2008. As described in Sect. 2.2.5, monthly variations of emissions were determined only if monthly activity data or proxy data were available; otherwise, emissions were considered to be constant throughout the year. Therefore, these monthly variations often depend on residential and cold start emissions, whose monthly fractions are determined from surface temperature and can be determined for all countries and regions. That appears to be true in Fig. 11 for OSA and RCA, where monthly emissions of $\mathrm{NO}_{\mathrm{x}}$ and $\mathrm{BC}$ are higher in winter and lower in summer. Emissions in SEA were nearly constant within each year because seasonal variations of surface temperature are small and few data were
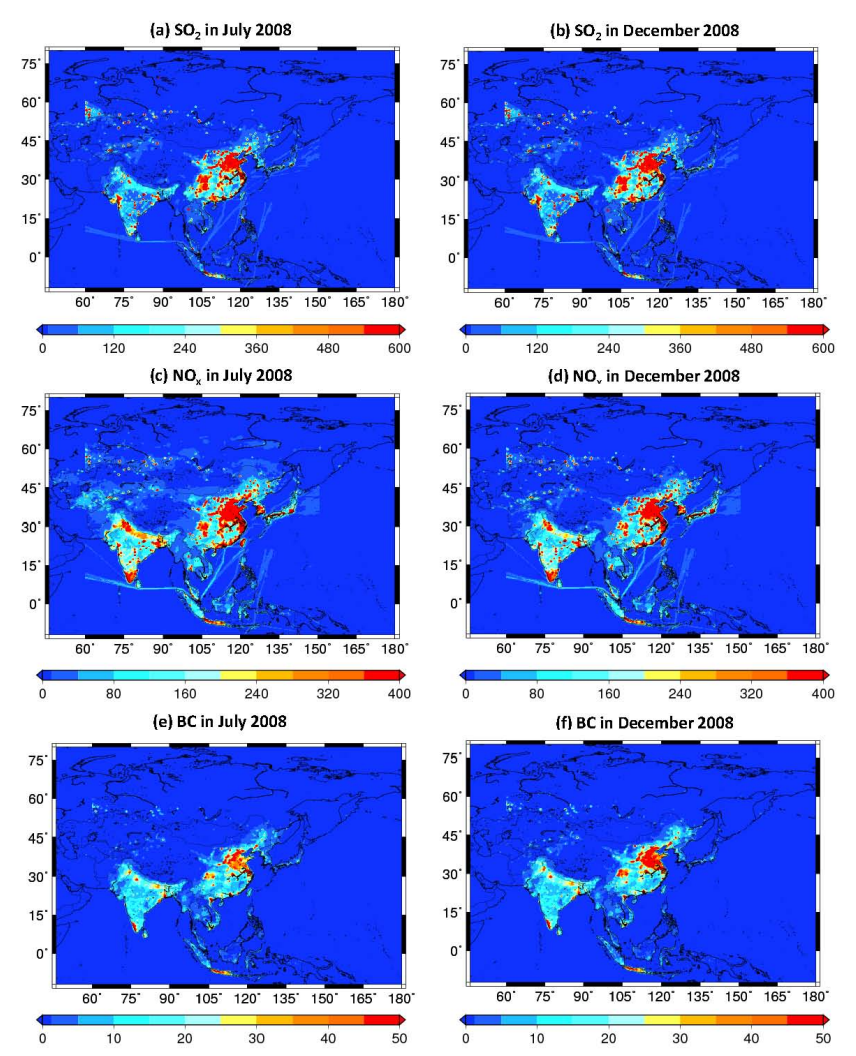

Fig. 8. Spatial distributions of monthly emissions $\left(\mathrm{Mg} \mathrm{month}^{-1}\right.$ per grid cell) of $\mathrm{SO}_{2}, \mathrm{NO}_{\mathrm{x}}$, and $\mathrm{BC}$ in July and December 2008.

available for estimating monthly fractions of other sectors. In OEA, monthly variations were basically governed by those in Japan, which were estimated from JEI-DB (Sect. 2.5), whereas very limited monthly data were available for other countries. Seasonal variations of $\mathrm{SO}_{2}$ in Japan were generally small, whereas those of $\mathrm{NO}_{\mathrm{x}}$ and $\mathrm{BC}$ were mainly controlled by emissions from the road transport sector and reflected cold start emissions in winter. Large gaps sometimes appear between December and January in Fig. 11 and will affect the results of simulations by chemical transport model. This issue should be improved by collection of continuous monthly data and use of inverse modeling.

In Fig. 8c, d, $\mathrm{NO}_{\mathrm{x}}$ emissions were higher in July than in December, especially over rural and higher latitude areas. Most of these seasonal differences were caused by soil $\mathrm{NO}_{\mathrm{x}}$ emissions, which respond to surface soil temperature and leaf area index (Yan et al., 2005). Although the contribution of soil sources to total $\mathrm{NO}_{\mathrm{x}}$ emissions was about $10 \%$ in China (see Sect. 3.1.2) the monthly variation was much greater than for other sources, as the average fraction ranged from about 0.01 in January and 0.21 in July. Seasonal variations of agricultural emissions, which were the majority of $\mathrm{NH}_{3}, \mathrm{CH}_{4}$, and $\mathrm{N}_{2} \mathrm{O}$ emissions, are not considered in REAS 2.1 as described in Sect. 2.2.5 (except for $\mathrm{NH}_{3}$ emissions in Japan). Better data on the seasonality of $\mathrm{NH}_{3}$ emissions will improve 
(a) Monthly fractions: $\mathrm{SO}_{2}$

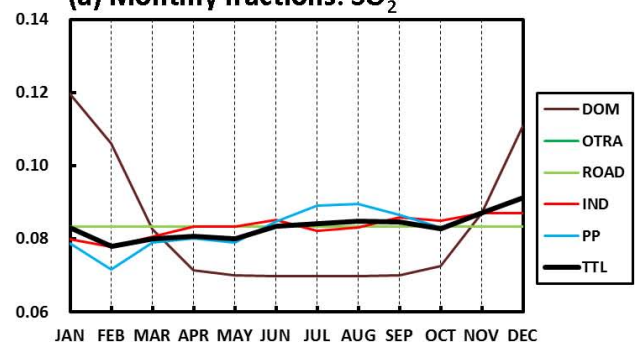

(c) Monthly fractions: $\mathrm{NO}_{\mathrm{x}}$

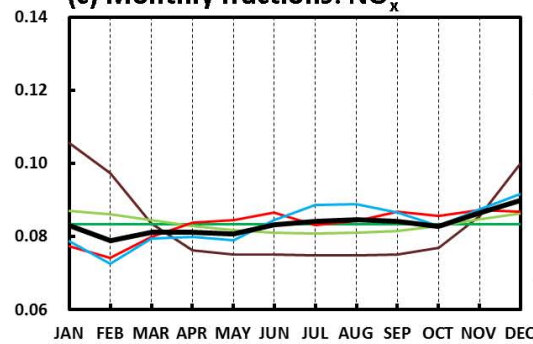

(e) Monthly fractions: BC

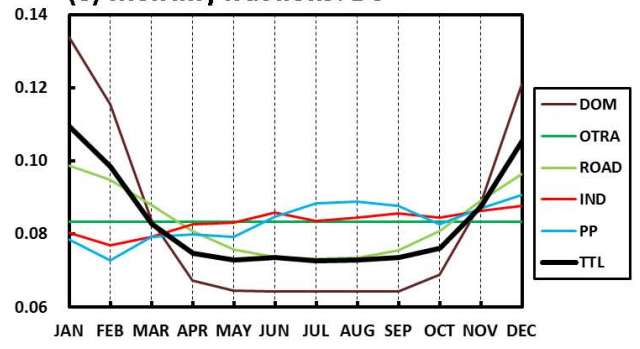

(b) Trends of monthly emissions: $\mathrm{SO}_{2}$

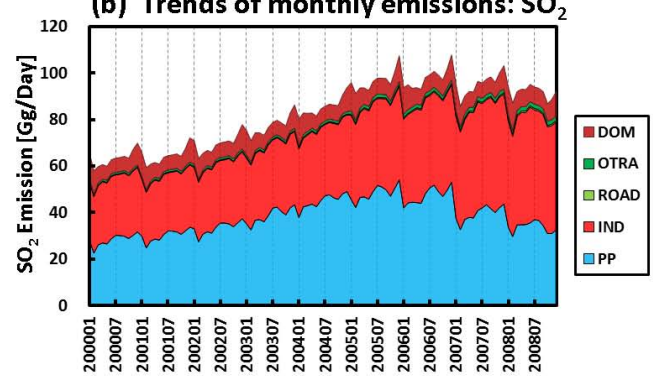

(d) Trends of monthly emissions: $\mathrm{NO}_{x}$

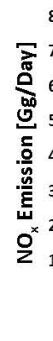

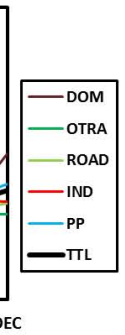

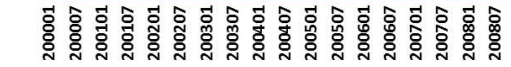

(f) Trends of monthly emissions: $B C$

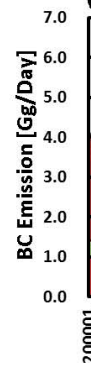

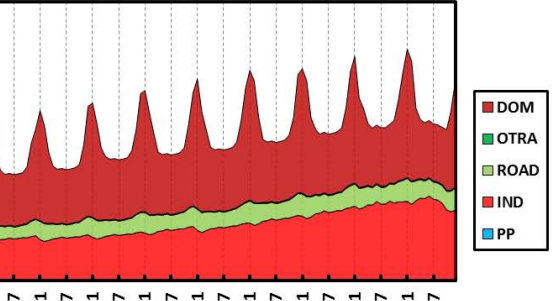

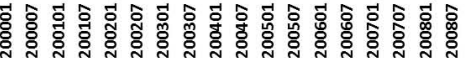

Fig. 9. Fractions (left panels) and trends (right panels) of monthly anthropogenic emissions of $\mathrm{SO}_{2}, \mathrm{NO}_{\mathrm{x}}$, (other than soil) and $\mathrm{BC}$ in $\mathrm{China}$ $\left(\mathrm{Gg} \mathrm{day}^{-1}\right)$. Monthly fractions are average of all values between 2000 and 2008. Abbreviations are the same as Fig. 4; plus TTL=Total.

the model reproducibility of aerosol concentrations, acidity of soils, and other environmental metrics.

With respect to species other than $\mathrm{SO}_{2}, \mathrm{NO}_{\mathrm{x}}$, and $\mathrm{BC}$, monthly variation of $\mathrm{CO}, \mathrm{PM}_{10}, \mathrm{PM}_{2.5}$, and $\mathrm{OC}$ is generally controlled by emissions from combustion of fossil and biofuels in domestic sector. Therefore, seasonality of these species is similar to that of $\mathrm{BC}$. Seasonal variation of $\mathrm{CO}_{2}$ emissions is similar to that of anthropogenic emissions of $\mathrm{NO}_{\mathrm{x}}$. As for $\mathrm{NMVOC}, \mathrm{NH}_{3}, \mathrm{CH}_{4}$, and $\mathrm{N}_{2} \mathrm{O}$, monthly variation of emissions from fossil and biofuel combustion is similar to that of $\mathrm{NO}_{\mathrm{x}}$ and $\mathrm{BC}$, respectively. However, as described in Sect. 2.2.5, we assumed no seasonal variation in evaporative emissions in NMVOC and agricultural emissions in $\mathrm{NH}_{3}$, $\mathrm{CH}_{4}$, and $\mathrm{N}_{2} \mathrm{O}$. As a result, monthly variation of total emissions of these species was relatively small. Improvement of monthly variation of agricultural emissions is one of major issues for the next version of REAS.

\subsection{Comparison with REAS version 1}

Figure 12 compares the 2000 emissions of five Asian regions (China, India, OEA, SEA, and OSA) under REAS 1.1 and 2.1 (abbreviated as Rv1 and Rv2 in this section and Sect. 3.5). We selected the year 2000 because it is the base year of Rv1. There are several reasons for the differences between Rv1 and Rv2. For activity data such as energy consumption and industrial production, statistics were sometimes updated. As mentioned in Sect. 2.3, different sources were used for some of the energy data in Rv1 and Rv2, such as consumption of fossil fuels other than coal in China and biofuels. Emission factors and removal efficiencies were updated (Sect. 2.4), and the methodology for estimating road transport emissions was changed (Sect. 2.2.2).

In China (Fig. 12a), $\mathrm{SO}_{2}$ emissions were about $17 \%$ smaller in Rv2 than in Rv1 because of the difference in industrial sectors. In Rv1, sulfur retention in coal ash after combustion in the industrial sector was at $15 \%$, but in Rv2 this value was changed to $25 \%$ after Lu et al. (2010). For $\mathrm{NO}_{\mathrm{x}}$, differences in energy statistics, emission factors, and 
(a) Monthly fractions: $\mathrm{SO}_{2}$

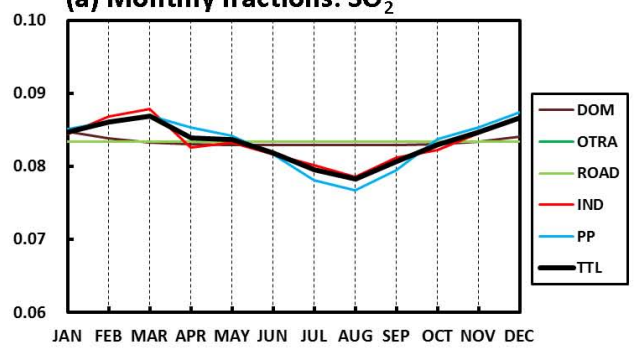

(c) Monthly fractions: $\mathrm{NO}_{\mathrm{x}}$

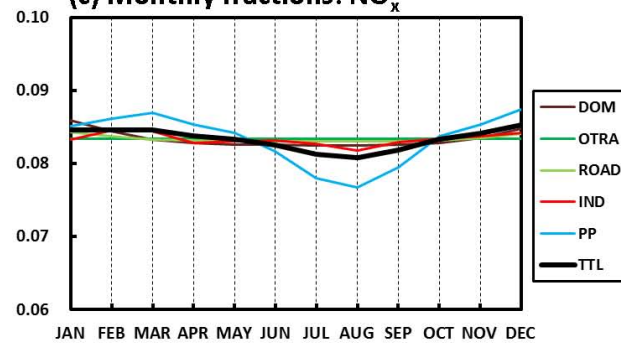

(e) Monthly fractions: BC

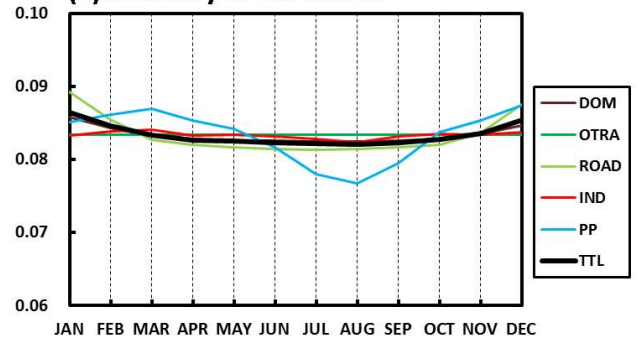

(b) Trends of monthly emissions: $\mathrm{SO}_{2}$

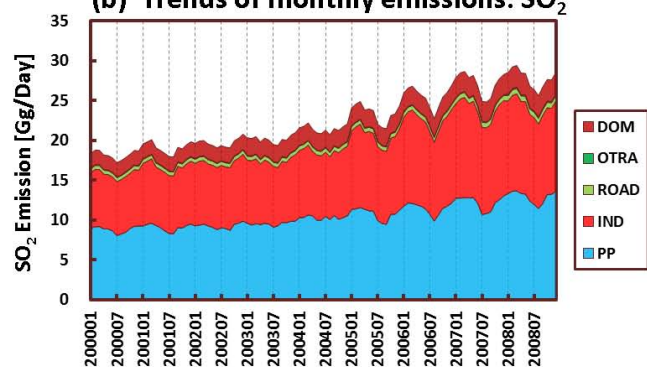

(d) Trends of monthly emissions: $\mathrm{NO}_{\mathrm{x}}$

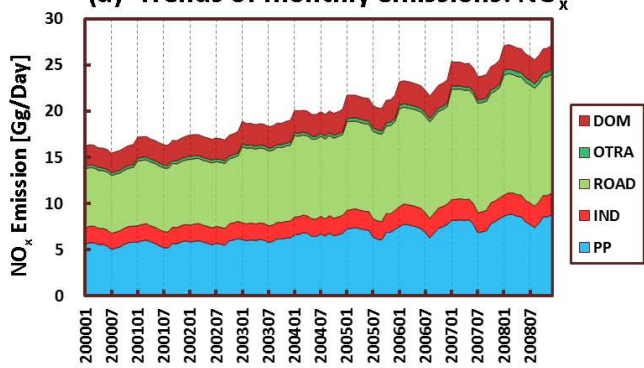

(f) Trends of monthly emissions: $\mathrm{BC}$

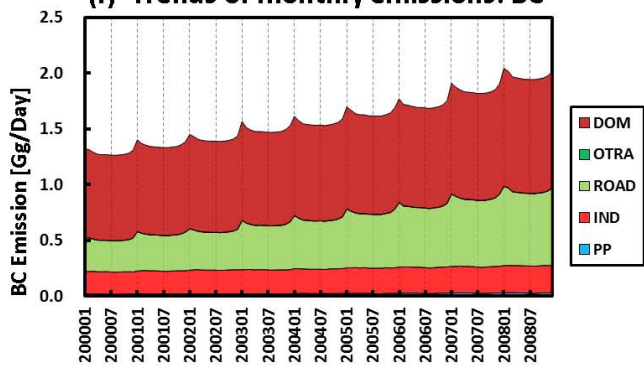

Fig. 10. Fractions (left panels) and trends (right panels) of monthly anthropogenic emissions of $\mathrm{SO}_{2}, \mathrm{NO}_{\mathrm{x}}$, (other than soil) and $\mathrm{BC}$ in India $\left(\mathrm{Gg}_{\mathrm{day}}{ }^{-1}\right)$. Monthly fractions are average of all values between 2000 and 2008. Abbreviations are the same as Fig. 9.

methodology for road transport have influenced the results for each sector, the results being increased emissions from the power plant, road transport and domestic sectors and reduced industrial emissions. The total $\mathrm{NO}_{\mathrm{x}}$ emissions were about $10 \%$ larger in Rv2 than in Rv1, but discrepancies between inventories in relative ratios of emissions from each sector were not large. Total emissions of $\mathrm{CO}, \mathrm{BC}$, and $\mathrm{OC}$ differed little between Rv1 and Rv2, but the relative sector contributions changed. Whereas the majority of $\mathrm{CO}$ emissions in the transport sector are from gasoline cars in both Rv1 and Rv2, the amount of emissions are much larger for Rv2. Emission factors for gasoline cars in China are almost the same in Rv1 and Rv2. Therefore traffic volumes in Rv2, as calculated by number of vehicles and annual distance traveled, are larger than in Rv1, as calculated by gasoline consumption and fuel economy. In addition, about $30 \%$ of road transport emissions of CO for the year 2000 in Rv2 are from cold start emissions, which are not included in Rv1. For BC and $\mathrm{OC}$, emissions from the industrial sector are larger and those from the domestic sector are smaller in Rv2 compared to Rv1. In the absence of emission factors, the latter did not include emissions from production of coke and bricks. However, these emissions are considered in Rv2 (after Lei et al., 2011a), where their contributions were about $60 \%$ of the industrial sector. For the domestic sector, emission factors for $\mathrm{BC}$ from coal combustion and for OC from biofuel combustion were smaller in Rv2 than in Rv1. NMVOC emissions in Rv1 (Sect. 2.1) were developed by Klimont et al. (2002a) and Streets et al. (2003a), when activity data were mostly projected values. Therefore, updates of both emission factors and activity data caused the difference in NMVOC emissions in each sector. This explanation can be applied not only to China but also to other countries and regions.

In India, SEA, and OSA (Fig. 12b, d, e, respectively), differences between Rv1 and Rv2 in $\mathrm{SO}_{2}$ emissions from each sector were relatively small, although total emissions in Rv2 were slightly larger in India and smaller in OSA. For $\mathrm{NO}_{\mathrm{x}}$, road transport emissions in India and SEA were about 50\% larger and 30\% smaller, respectively, in Rv2 than in Rv1. Emission factors for diesel buses and trucks in India were about $60 \%$ larger in Rv2 than in Rv1. Emission factors for SEA used in Rv1 and Rv2 were almost the same. Thus traffic 
(a) $\mathrm{SO}_{2}$

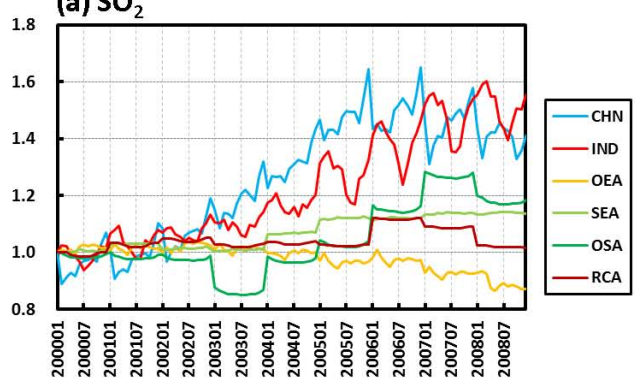

(c) BC

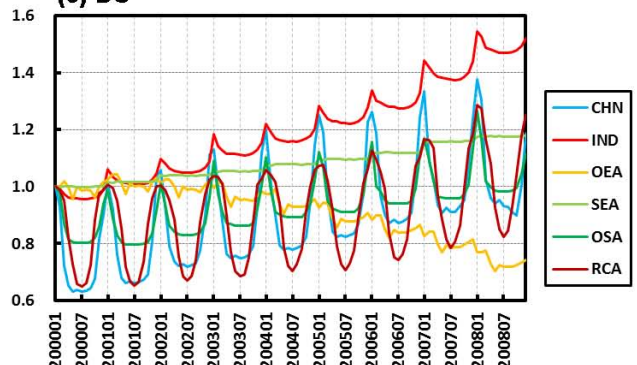

(b) $\mathrm{NO}_{x}$

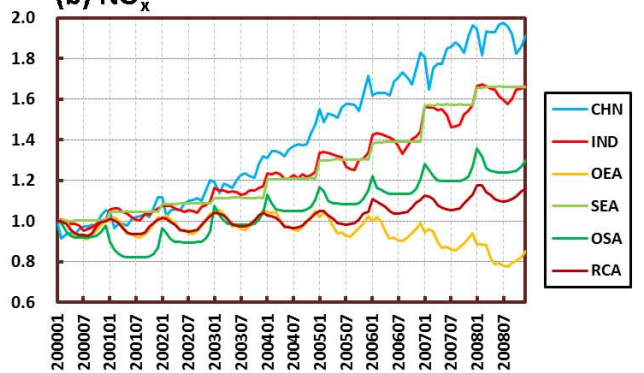

Fig. 11. Trends of monthly anthropogenic emissions of $\mathrm{SO}_{2}, \mathrm{NO}_{\mathrm{x}}$ (other than soil), and $\mathrm{BC}$ in each region from 2000 to 2008 . Values are normalized at emissions in January 2000. Abbreviations are the same as Fig. 4.

volumes for SEA were smaller in Rv2 than in Rv1. For CO, $\mathrm{BC}$, and $\mathrm{OC}$, emissions from the domestic sector (mostly from biofuel combustion) were much smaller in Rv2 than in Rv1 for all three regions. Rv2 adopted smaller emission factors for biofuel combustion than Rv1 based on Gurjar et al. (2004) and Venkataraman et al. (2005). In addition, biofuel consumptions by India and OSA for Rv2, taken from IEA Energy Balances (IEA, 2011) were respectively about $30 \%$ and $20 \%$ smaller than those for Rv1. For NMVOC, emissions from stationary combustion sources in India and OSA were much higher for Rv2 than Rv1 because of high emission factors for biofuel, especially for dung cake (Gurjar et al., 2004).

Emission data for Japan, South Korea, and Taiwan were obtained from different sources in Rv2 than in Rv1 (Sect. 2.5). Table $\mathrm{S} 4$ in the Supplement shows the total emissions of $\mathrm{SO}_{2}, \mathrm{NO}_{\mathrm{x}}, \mathrm{CO}, \mathrm{BC}, \mathrm{OC}$, and NMVOC in these countries. For Japan, differences between Rv1 and Rv2 for $\mathrm{SO}_{2}$ and NMVOC emissions were within $10 \%$, but there were large discrepancies for other species. $\mathrm{NO}_{\mathrm{x}}$ emissions were about $35 \%$ larger in Rv2 than in Rv1, mainly because of road transport emissions. $\mathrm{CO}$ emissions were much larger, by a factor of 2.6. The larger BC and OC emissions in Rv1 than Rv2 in Japan were mainly caused by sources other than the transport sector, although road transport emissions were also smaller in Rv2. Stationary emissions of BC and OC were respectively more than $35 \%$ and $60 \%$ of total emissions in Rv1 and less than $20 \%$ and $30 \%$, respectively, in Rv2. For South Korea, emissions of all species were much larger in $\mathrm{Rv} 1$ than in $\mathrm{Rv} 2 . \mathrm{SO}_{2}$ emissions in the industry sector were larger in Rv1 than in Rv2 by a factor of 3, and $\mathrm{NO}_{\mathrm{x}}$ emissions in the road transport sector were twice as large in $\mathrm{Rv} 1$ as in Rv2. Emissions of $\mathrm{CO}, \mathrm{BC}$, and $\mathrm{OC}$, from other than road transport were almost negligible in Rv2 but made relative contributions in Rv1 of about $70 \%, 50 \%$, and $80 \%$, respectively. NMVOC emissions from solvent and paint use were almost unchanged between Rv1 and Rv2, but contributions from road transport and extraction and processing of fossil fuels were much larger in Rv1 than in Rv2. For Taiwan, emissions were larger in Rv1 than in Rv2 for all species except $\mathrm{BC}$, for which road transport emissions were much smaller in Rv1 than in Rv2. Differences between Rv1 and $\mathrm{Rv} 2$ for $\mathrm{SO}_{2}$ and $\mathrm{CO}$ were similar to those for South Korea. For OC, emissions from the industrial and transport sectors were almost the same in Rv1 and Rv2, whereas those from other sectors were larger in Rv1 than in Rv2. Differences of $\mathrm{NO}_{\mathrm{x}}$ emissions were relatively small. NMVOC emissions in Rv2 were about $50 \%$ larger than in Rv1 due to differences in fuel combustion and solvent use sources. In North Korea and Mongolia, emissions of BC and OC are much smaller in Rv2 than in Rv1, a response to decreased biofuel consumption in the activity data of Rv2 compared to Rv1.

\subsection{Comparison with other inventories}

Table 8 summarizes emissions of $\mathrm{SO}_{2}, \mathrm{NO}_{\mathrm{x}}, \mathrm{CO}$, NMVOC, $\mathrm{PM}_{10}, \mathrm{PM}_{2.5}, \mathrm{BC}$, and $\mathrm{OC}$ in China estimated by Rv2 and several other published inventories. The year-to-year variation of $\mathrm{SO}_{2}$ in Rv2 is very similar to that of Lu et al. (2010). This similarity is reasonable because $\mathrm{Lu}$ et al. (2010) was the source of the penetration ratios of FGD in power plants 
Table 8. Published estimates of emissions of $\mathrm{SO}_{2}, \mathrm{NO}_{\mathrm{x}}, \mathrm{CO}, \mathrm{NMVOC}, \mathrm{BC}$, and $\mathrm{OC}$ from China $\left(\mathrm{Tg} \mathrm{yr}^{-1}\right)$.

\begin{tabular}{|c|c|c|c|c|c|c|c|c|c|}
\hline & 2000 & 2001 & 2002 & 2003 & 2004 & 2005 & 2006 & 2007 & 2008 \\
\hline \multicolumn{10}{|c|}{$\mathrm{SO}_{2}$} \\
\hline Streets et al. (2003a) & 20.3 & & & & & & & & \\
\hline Ohara et al. (2007) & 27.6 & 29.3 & 31.9 & 36.6 & & & & & \\
\hline Klimont et al. (2009) & 23.1 & & & & & 34.3 & & & \\
\hline Zhang et al. (2009a) & & 22.9 & & & & & 31.0 & & \\
\hline Lu et al. (2010) & 21.7 & 22.7 & 24.0 & 26.7 & 28.8 & 32.3 & 33.2 & 32.3 & 31.3 \\
\hline Lu et al. (2011) & 21.1 & & & & 30.5 & & & & 32.0 \\
\hline Smith et al. (2011) & 21.4 & & & & & 32.7 & & & \\
\hline Zhao et al. (2011) & & & & & & 31.1 & & & \\
\hline EDGAR 4.2 & 20.1 & 19.9 & 20.7 & 23.7 & 27.6 & 30.1 & 32.5 & 34.7 & 40.3 \\
\hline This work & 23.0 & 23.3 & 25.2 & 28.1 & 31.1 & 35.2 & 35.5 & 34.6 & 33.5 \\
\hline \multicolumn{10}{|c|}{$\mathrm{NO}_{\mathrm{x}}$} \\
\hline Streets et al. (2003a) & 10.5 & & & & & & & & \\
\hline Ohara et al. (2007) & 11.2 & 11.8 & 12.7 & 14.5 & & & & & \\
\hline Zhang et al. (2007) & 12.6 & 13.2 & 14.4 & 16.2 & 18.6 & & & & \\
\hline Zhang et al. (2009a) & & 13.4 & & & & & 20.8 & & \\
\hline Klimont et al. (2009) & 11.6 & & & & & 16.9 & & & \\
\hline Zhao et al. (2011) & & & & & & 19.8 & & & \\
\hline EDGAR 4.2 & 11.2 & 11.1 & 11.5 & 13.1 & 14.7 & 15.8 & 17.0 & 18.1 & 20.0 \\
\hline This work & 12.7 & 13.3 & 14.3 & 15.8 & 17.9 & 20.4 & 22.0 & 23.9 & 25.1 \\
\hline \multicolumn{10}{|c|}{$\mathrm{CO}$} \\
\hline Streets et al. (2003a) & 100.0 & & & & & & & & \\
\hline Streets et al. (2006) & & 141.7 & & & & & & & \\
\hline Ohara et al. (2007) & 137.0 & 140.6 & 146.3 & 158.3 & & & & & \\
\hline Zhang et al. (2009a) & & 141.6 & & & & & 166.9 & & \\
\hline EDGAR 4.2 & 73.9 & 73.5 & 74.7 & 77.6 & 84.2 & 89.1 & 93.8 & 98.6 & 105.1 \\
\hline This work & 141.8 & 142.8 & 149.4 & 158.1 & 168.5 & 186.6 & 190.2 & 196.1 & 202.0 \\
\hline \multicolumn{10}{|c|}{ NMVOC } \\
\hline Klimont et al. (2002a) & 15.6 & & & & & & & & \\
\hline Streets et al. (2003a) & 14.7 & & & & & & & & \\
\hline Ohara et al. (2007) & 14.7 & 15.5 & 16.1 & 17.2 & & & & & \\
\hline Bo et al. (2008) & 10.2 & & & & & 15.6 & & & \\
\hline Wei et al. (2008) & & & & & & 19.2 & & & \\
\hline Zhang et al. (2009a) & & 18.1 & & & & & 23.2 & & \\
\hline EDGAR 4.2 & 16.8 & 17.0 & 17.4 & 18.0 & 19.1 & 19.8 & 20.6 & 21.1 & 22.2 \\
\hline This work & 15.8 & 16.7 & 17.8 & 19.3 & 21.8 & 23.3 & 25.3 & 26.8 & 27.1 \\
\hline \multicolumn{10}{|c|}{$\mathrm{PM}_{10}$} \\
\hline Zhang et al. (2009a) & & 16.1 & & & & & 18.2 & & \\
\hline Lei et al. (2011) & 16.1 & & & & & 18.8 & & & \\
\hline Zhao et al. (2011) & & & & & & 19.2 & & & \\
\hline EDGAR 4.2 & 11.3 & 10.7 & 10.7 & 11.4 & 11.8 & 12.5 & 13.0 & 13.5 & 14.7 \\
\hline This work & 14.0 & 14.4 & 15.2 & 16.3 & 17.6 & 19.2 & 20.3 & 21.4 & 21.6 \\
\hline \multicolumn{10}{|c|}{$\mathrm{PM}_{2.5}$} \\
\hline Zhang et al. (2009a) & & 11.7 & & & & & 13.3 & & \\
\hline Lei et al. (2011) & 10.8 & & & & & 13.0 & & & \\
\hline Zhao et al. (2011) & & & & & & 13.1 & & & \\
\hline This work & 9.47 & 9.88 & 10.5 & 11.3 & 12.2 & 13.3 & 13.9 & 14.5 & 14.5 \\
\hline
\end{tabular}


(a) China

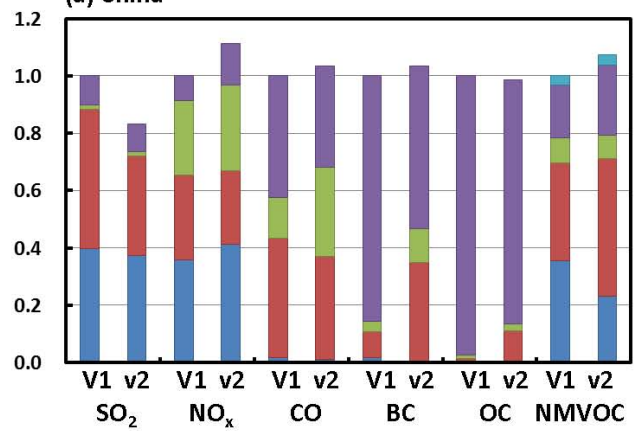

(c) East Asia outside China

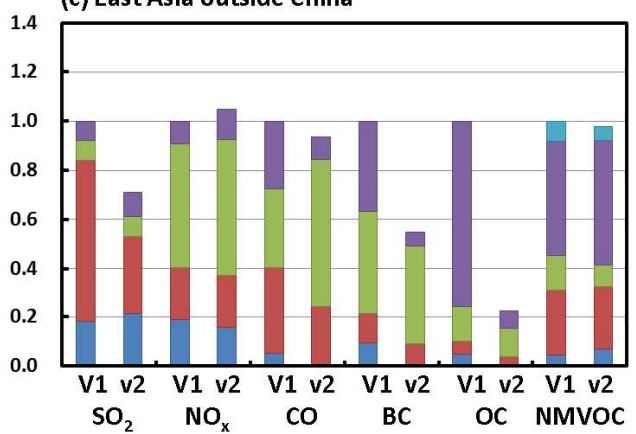

(e) South Asia outside India

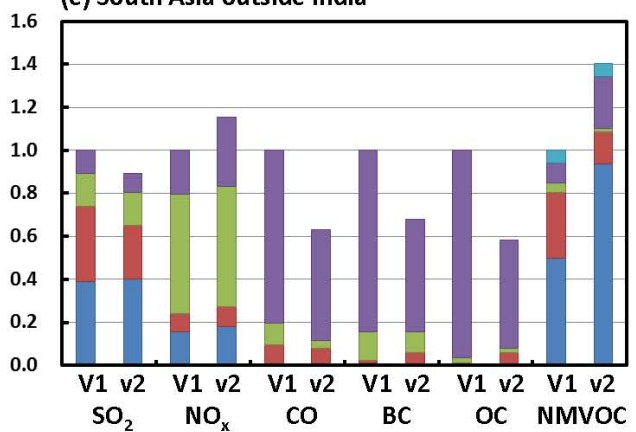

(b) India

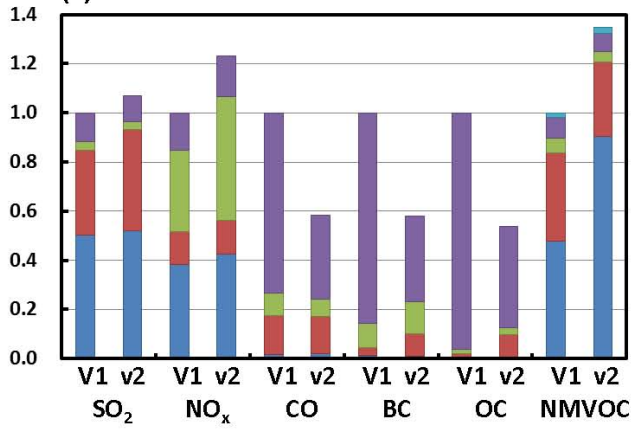

(d) Southeast Asia

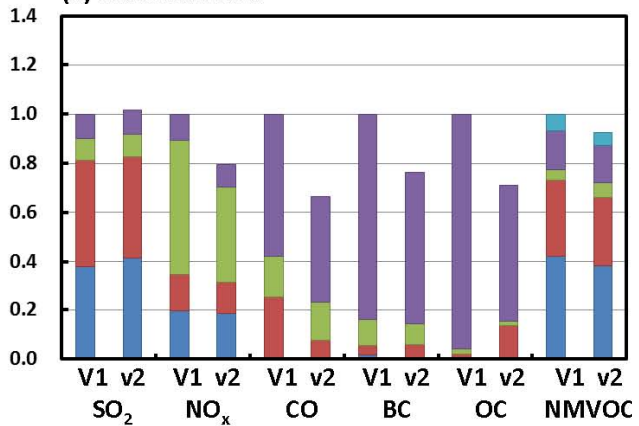

Fig. 12. Comparison of $\mathrm{SO}_{2}, \mathrm{NO}_{\mathrm{x}}$ (other than soil), $\mathrm{CO}, \mathrm{BC}, \mathrm{OC}$, and NMVOC emissions in 2000 in REAS version 1 (v1) and 2 (v2) for (a) China, (b) India, (c) East Asia outside China, (d) Southeast Asia and (e) South Asia outside India for various sectors (PP = Power plants, $\mathrm{IND}=$ Industry, TRA = Transport, $\mathrm{DOM}=$ Domestic, $\mathrm{SCMB}=$ Stationary combustion, INP = Industrial processes, SLV = Solvent and paint use, MISC $=$ Miscellaneous). Values are normalized to those in REAS version 1.

that strongly affected the trends of total $\mathrm{SO}_{2}$ emissions. The amounts of $\mathrm{SO}_{2}$ emissions are slightly larger in $\mathrm{Rv} 2$ than in Lu et al. (2010), Smith et al. (2011), and Zhao et al. (2011) but agreed very well with in Klimont et al. (2009). EDGAR 4.2 (EC-JRC/PBL, 2011; hereafter EDGAR) does not appear to consider the effects of FGD penetration sufficiently fast. Emission factors of $\mathrm{NO}_{\mathrm{x}}$ were mainly from Zhang et al. (2007). Therefore, emissions in Rv2 during the period 2000-2004 and 2006 were similar to those in Zhang et al. (2007, 2009a), respectively. Compared to EDGAR, emissions of Rv2 were larger, especially after 2005 (nearly $30 \%$ larger), but agreed very well with those of Zhao et al. (2011) for 2005. For CO, amounts of emissions in 2001 were very similar in Streets et al. (2006), Ohara et al. (2007), Zhang et al. (2009a) and Rv2. Emission factors in Rv2 were primarily from Streets et al. (2006). CO emissions for 2006 were about $15 \%$ larger in Rv2 than in Zhang et al. (2009a). Emissions of CO in EDGAR were about half of the emissions in other inventories, but the growth rates between 2000 and 2008 for Rv2 and EDGAR were almost the same (about $42 \%$ ), indicating that the applied emission factor derived from common European techniques seems not valid for Asian technology. All NMVOC emissions in 2000 in Table 8 are within $15 \%$ except for Bo et al. (2008), whose results are smaller than others results in 2000 and 2005. Compared to Zhang et al. (2009a), NMVOC emissions in Rv2 are smaller in 2001 but larger in 2006, the result being that estimated growth rates in Rv2 are larger than in Zhang et al. (2009a). The 
Table 8. Continued.

\begin{tabular}{|c|c|c|c|c|c|c|c|c|c|}
\hline \multicolumn{10}{|c|}{$\mathrm{BC}$} \\
\hline & & & & & & & & & \\
\hline Cao et al. (2006) & 1.40 & & & & & & & & \\
\hline Bond et al. (2007) & 1.25 & & & & & & & & \\
\hline Ohara et al. (2007) & 1.09 & 1.10 & 1.11 & 1.14 & & & & & \\
\hline Klimont et al. (2009) & 1.24 & & & & & 1.26 & & & \\
\hline Zhang et al. (2009a) & & 1.60 & & & & & 1.81 & & \\
\hline Lu et al. (2011) & 1.16 & & & & 1.47 & & & & 1.68 \\
\hline Lei et al. (2011a) & 1.18 & & & & 1.51 & & & & \\
\hline Zhao et al. (2011) & & & & & & 1.70 & & & \\
\hline Qin and Xie (2012) & 1.14 & 1.20 & 1.29 & 1.36 & 1.35 & 1.52 & 1.55 & 1.56 & 1.61 \\
\hline This work & 1.14 & 1.18 & 1.27 & 1.33 & 1.37 & 1.46 & 1.52 & 1.56 & 1.59 \\
\hline \multicolumn{10}{|c|}{$\mathrm{OC}$} \\
\hline Streets et al. (2003a) & 2.66 & & & & & & & & \\
\hline Cao et al. (2006) & 3.82 & & & & & & & & \\
\hline Bond et al (2007) & 2.50 & & & & & & & & \\
\hline Ohara et al. (2007) & 2.56 & 2.58 & 2.60 & 2.62 & & & & & \\
\hline Klimont et al (2009) & 2.87 & & & & & 2.49 & & & \\
\hline Zhang et al. (2009a) & & 2.83 & & & & & 3.22 & & \\
\hline Lu et al. (2011) & 2.41 & & & & 3.13 & & & & 3.37 \\
\hline Lei et al. (2011a) & 2.54 & & & & 3.19 & & & & \\
\hline Zhao et al. (2011) & & & & & & 3.20 & & & \\
\hline This work & 2.53 & 2.66 & 2.91 & 2.98 & 3.07 & 3.13 & 3.13 & 3.08 & 3.08 \\
\hline
\end{tabular}

growth rate for NMVOC between 2000 and 2008 in Rv2 (about $70 \%$ ) was much larger than in EDGAR (about 30\%). With respect to $\mathrm{PM}$, emissions of $\mathrm{PM}_{10}$ and $\mathrm{PM}_{2.5}$ in Rv2 agreed well with in Zhang et al. (2009a), Lei et al. (2011) and Zhao et al. (2012). However, emissions of $\mathrm{PM}_{10}$ in Rv2 were much higher than in EDGAR. BC emissions in Rv2 were very similar to those of Qin and Xie (2012) as well as Lei et al. (2011a) and Lu et al. (2011). BC emissions for 2001 and 2006 in RV2 were both smaller than in Zhang et al. (2009a), but growth rates for that period were larger (about $30 \%$ compared to about $15 \%$ ). All OC emissions for 2000 showed similar values except for Cao et al. (2006). BC and OC emissions in 2000 estimated by Cao et al. (2006) were about $25 \%$ and $50 \%$ larger, respectively, than in Rv2. From 2001 to 2008, differences in OC emissions between Rv2 and other inventories were less than $15 \%$. However, trends of Rv2 were almost the same in 2004 and 2008, whereas those of Lu et al. (2011) increased by about $8 \%$ from 2004 to 2008 . OC emissions in Rv2 decreased after 2006 because of the reduction of biofuel consumption in China. Emissions of BC in Bond et al. (2007) and Zhao et al. (2011) were higher than in $\mathrm{Rv} 2$ but those of OC were agreed well. BC and OC emissions in Rv2 showed increasing trends from 2000 to 2005. On the other hand, BC emissions in 2000 and 2005 were almost the same and OC emissions were decreased from 2000 to 2005 in Klimont et al. (2009).

Table 9 lists the emissions in India estimated by Rv2 and other inventories. For $\mathrm{SO}_{2}, \mathrm{NO}_{\mathrm{x}}$, and $\mathrm{NMVOC}$, emissions in Rv2 were higher than other inventories all through the period. $\mathrm{SO}_{2}$ emissions of Streets et al. (2003a), Klimont et al. (2009), Lu et al. (2011), Smith et al. (2011) and EDGAR are relatively similar but about $15-25 \%$ smaller than the Rv2 emissions. Growth rates between 2000 and 2008 were about $38 \%, 48 \%$, and $53 \%$ in Lu et al. (2011), EDGAR, and Rv2, respectively. $\mathrm{SO}_{2}$ emissions of Garg et al. (2006) and Zhang et al. (2009a) are much smaller than the Rv2 emissions, perhaps because Rv2 uses larger net emission factors. The $\mathrm{NO}_{\mathrm{x}}$ and NMVOC emissions have similar patterns for $\mathrm{SO}_{2}$ across the inventories. In addition, growth rates from 2000 to 2008 in Rv2 (about $66 \%$ and $37 \%$ for $\mathrm{NO}_{\mathrm{x}}$ and NMVOC, respectively) were much larger than those of EDGAR (about $40 \%$ and $11 \%$ ). The rate of increase of road transport emissions in Rv2 is much larger than in EDGAR. For CO, emissions in Rv2 and other inventories were all within $15 \%$ in 2000, except for Ohara et al. (2007); however, the growth rate from 2000 to 2008 was larger in Rv2 (about $33 \%$ ) than in EDGAR (about $11 \%$ ). With respect to PM, emissions of $\mathrm{PM}_{10}$ and $\mathrm{PM}_{2.5}$ in Rv2 were more than $40 \%$ higher than in Zhang et al. (2009a). On the other hand, $\mathrm{PM}_{10}$ emissions in EDGAR were about 60-80\% larger than in Rv2. BC emissions were smaller in Rv2 than in other inventories except for Zhang et al. (2009a), whose emissions in 2006 are about $45 \%$ smaller than the Rv2 emissions. BC emissions of $\mathrm{Lu}$ et al. (2011) are about $47 \%, 38 \%$, and $25 \%$ larger than Rv2 for 2000, 2004, and 2008, respectively. Therefore, growth rates from 2000 to 2008 in $\operatorname{Rv} 2$ (about $54 \%$ ) are larger than 
Table 9. Published estimates of emissions of $\mathrm{SO}_{2}, \mathrm{NO}_{\mathrm{x}}, \mathrm{CO}, \mathrm{NMVOC}, \mathrm{BC}$, and OC from India $\left(\mathrm{Tg} \mathrm{yr}^{-1}\right)$.

\begin{tabular}{|c|c|c|c|c|c|c|c|c|c|}
\hline & 2000 & 2001 & 2002 & 2003 & 2004 & 2005 & 2006 & 2007 & 2008 \\
\hline \multicolumn{10}{|c|}{$\mathrm{SO}_{2}$} \\
\hline Streets et al. (2003a) & 5.46 & & & & & & & & \\
\hline Garg et al. (2006) & 4.05 & & & & & 4.59 & & & \\
\hline Ohara et al. (2007) & 6.14 & 6.47 & 6.74 & 7.02 & & & & & \\
\hline Klimont et al. (2009) & 5.11 & & & & & 6.40 & & & \\
\hline Zhang et al. (2009a) & & & & & & & 5.60 & & \\
\hline Lu et al. (2011) & 5.77 & & & & 6.45 & & & & 7.99 \\
\hline Smith et al. (2011) & 5.36 & & & & & 6.28 & & & \\
\hline EDGAR 4.2 & 5.76 & 5.79 & 6.05 & 6.18 & 6.46 & 6.77 & 7.36 & 7.90 & 8.52 \\
\hline This work & 6.57 & 6.88 & 7.10 & 7.29 & 7.77 & 8.47 & 9.21 & 9.81 & 10.08 \\
\hline \multicolumn{10}{|c|}{$\mathrm{NO}_{\mathrm{x}}$} \\
\hline Streets et al. (2003a) & 4.05 & & & & & & & & \\
\hline Garg et al. (2006) & 3.64 & & & & & 4.37 & & & \\
\hline Ohara et al. (2007) & 4.73 & 4.75 & 4.86 & 4.97 & & & & & \\
\hline Klimont et al. (2009) & 4.12 & & & & & 5.05 & & & \\
\hline Zhang et al. (2009a) & & & & & & & 4.86 & & \\
\hline EDGAR 4.2 & 4.55 & 4.57 & 4.93 & 5.02 & 5.30 & 5.42 & 5.74 & 6.09 & 6.39 \\
\hline This work & 5.83 & 6.13 & 6.26 & 6.76 & 7.23 & 7.69 & 8.26 & 9.00 & 9.68 \\
\hline \multicolumn{10}{|c|}{$\mathrm{CO}$} \\
\hline Streets et al. (2003a) & 51.1 & & & & & & & & \\
\hline Garg et al. (2006) & 40.3 & & & & & 41.7 & & & \\
\hline Ohara et al. (2007) & 79.4 & 80.6 & 83.0 & 84.4 & & & & & \\
\hline Zhang et al. (2009a) & & & & & & & 61.1 & & \\
\hline EDGAR 4.2 & 41.6 & 41.8 & 43.3 & 44.1 & 43.5 & 44.1 & 44.7 & 45.7 & 46.3 \\
\hline This work & 46.3 & 47.5 & 49.0 & 50.4 & 51.8 & 53.9 & 55.9 & 58.7 & 61.8 \\
\hline \multicolumn{10}{|c|}{ NMVOC } \\
\hline Streets et al. (2003a) & 8.63 & & & & & & & & \\
\hline Ohara et al. (2007) & 8.64 & 8.95 & 9.34 & 9.68 & & & & & \\
\hline Zhang et al. (2009a) & & & & & & & 10.77 & & \\
\hline EDGAR 4.2 & 9.57 & 9.66 & 10.02 & 10.27 & 10.14 & 10.22 & 10.37 & 10.56 & 10.61 \\
\hline This work & 11.62 & 12.03 & 12.35 & 12.89 & 13.36 & 14.00 & 14.69 & 15.29 & 15.95 \\
\hline \multicolumn{10}{|c|}{$\mathrm{PM}_{10}$} \\
\hline Zhang et al. (2009a) & & & & & & & 4.00 & & \\
\hline EDGAR 4.2 & 8.45 & 8.45 & 8.56 & 8.80 & 9.19 & 9.43 & 9.84 & 10.3 & 10.9 \\
\hline This work & 4.72 & 4.87 & 4.97 & 5.10 & 5.40 & 5.59 & 5.87 & 6.26 & 6.65 \\
\hline \multicolumn{10}{|c|}{$\mathrm{PM}_{2.5}$} \\
\hline Zhang et al. (2009a) & & & & & & & 3.11 & & \\
\hline This work & 3.53 & 3.64 & 3.73 & 3.84 & 4.00 & 4.15 & 4.33 & 4.60 & 4.88 \\
\hline \multicolumn{10}{|c|}{$\mathrm{BC}$} \\
\hline Streets et al. (2003a) & 0.517 & & & & & & & & \\
\hline Bond et al. (2007) & 0.500 & & & & & & & & \\
\hline Ohara et al. (2007) & 0.795 & 0.802 & 0.819 & 0.832 & & & & & \\
\hline Klimont et al. (2009) & 0.773 & & & & & 0.965 & & & \\
\hline Zhang et al. (2009a) & & & & & & & 0.344 & & \\
\hline Lu et al. (2011) & 0.680 & & & & 0.772 & & & & 0.892 \\
\hline This work & 0.462 & 0.486 & 0.506 & 0.536 & 0.560 & 0.590 & 0.616 & 0.665 & 0.713 \\
\hline \multicolumn{10}{|c|}{$\mathrm{OC}$} \\
\hline Streets et al. (2003a) & 2.19 & & & & & & & & \\
\hline Bond et al. (2007) & 1.38 & & & & & & & & \\
\hline Ohara et al. (2007) & 3.27 & 3.32 & 3.37 & 3.42 & & & & & \\
\hline Klimont et al. (2009) & 1.67 & & & & & 1.93 & & & \\
\hline Zhang et al. (2009a) & & & & & & & 0.89 & & \\
\hline Lu et al. (2011) & 1.71 & & & & 1.99 & & & & 2.18 \\
\hline This work & 1.76 & 1.81 & 1.85 & 1.91 & 1.95 & 2.00 & 2.05 & 2.16 & 2.29 \\
\hline
\end{tabular}


Table 10. Published estimates of emissions of $\mathrm{SO}_{2}, \mathrm{NO}_{\mathrm{x}}, \mathrm{CO}, \mathrm{NMVOC}, \mathrm{BC}$, and $\mathrm{OC}$ in (a) East Asia outside China, (b) Southeast Asia, and (c) South Asia outside India $\left(\mathrm{Tg} \mathrm{yr}^{-1}\right)$.

\begin{tabular}{|c|c|c|c|c|c|c|c|c|c|}
\hline \multicolumn{10}{|l|}{ (a) East Asia outside China } \\
\hline & 2000 & 2001 & 2002 & 2003 & 2004 & 2005 & 2006 & 2007 & 2008 \\
\hline \multicolumn{10}{|c|}{$\mathrm{SO}_{2}$} \\
\hline Streets et al. (2003a) & 2.31 & & & & & & & & \\
\hline Ohara et al. (2007) & 2.56 & 2.52 & 2.43 & 2.39 & & & & & \\
\hline Zhang et al. (2009a) & & & & & & & 1.79 & & \\
\hline EDGAR 4.2 & 6.84 & 6.67 & 6.70 & 6.26 & 6.12 & 6.05 & 5.85 & 5.77 & 5.47 \\
\hline This work & 1.82 & 1.82 & 1.83 & 1.81 & 1.79 & 1.73 & 1.75 & 1.66 & 1.60 \\
\hline \multicolumn{10}{|c|}{$\mathrm{NO}_{\mathrm{x}}$} \\
\hline Streets et al. (2003a) & 4.33 & & & & & & & & \\
\hline Ohara et al. (2007) & 4.43 & 4.44 & 4.57 & 4.67 & & & & & \\
\hline Zhang et al. (2009a) & & & & & & & 4.66 & & \\
\hline EDGAR 4.2 & 5.47 & 5.44 & 5.59 & 5.23 & 5.22 & 5.16 & 5.08 & 5.04 & 4.77 \\
\hline This work & 4.65 & 4.67 & 4.74 & 4.85 & 4.85 & 4.71 & 4.59 & 4.35 & 3.98 \\
\hline \multicolumn{10}{|c|}{$\mathrm{CO}$} \\
\hline Streets et al. (2003a) & 15.0 & & & & & & & & \\
\hline Ohara et al. (2007) & 15.3 & 15.5 & 15.5 & 17.0 & & & & & \\
\hline Zhang et al. (2009a) & & & & & & & 11.7 & & \\
\hline EDGAR 4.2 & 21.1 & 20.7 & 20.4 & 20.0 & 19.7 & 19.1 & 18.8 & 18.5 & 17.4 \\
\hline This work & 14.4 & 14.2 & 14.0 & 13.9 & 13.9 & 13.9 & 13.6 & 12.5 & 12.3 \\
\hline \multicolumn{10}{|c|}{ NMVOC } \\
\hline Streets et al. (2003a) & 3.73 & & & & & & & & \\
\hline Ohara et al. (2007) & 3.74 & 3.78 & 3.82 & 3.89 & & & & & \\
\hline Zhang et al. (2009a) & & & & & & & 3.93 & & \\
\hline EDGAR 4.2 & 7.41 & 7.33 & 7.28 & 7.22 & 7.18 & 7.14 & 7.10 & 7.08 & 6.95 \\
\hline This work & 3.68 & 3.58 & 3.49 & 3.44 & 3.46 & 3.31 & 3.25 & 3.26 & 3.07 \\
\hline \multicolumn{10}{|c|}{$\mathrm{PM}_{10}$} \\
\hline Zhang et al. (2009a) & & & & & & & 0.927 & & \\
\hline EDGAR 4.2 & 1.99 & 1.96 & 1.36 & 1.08 & 1.14 & 1.06 & 1.07 & 1.03 & 1.02 \\
\hline This work & 0.714 & 0.720 & 0.711 & 0.705 & 0.702 & 0.715 & 0.710 & 0.684 & 0.696 \\
\hline \multicolumn{10}{|c|}{$\mathrm{PM}_{2.5}$} \\
\hline Zhang et al. (2009a) & & & & & & & 0.637 & & \\
\hline This work & 0.402 & 0.406 & 0.403 & 0.399 & 0.395 & 0.392 & 0.385 & 0.372 & 0.364 \\
\hline \multicolumn{10}{|c|}{$\mathrm{BC}$} \\
\hline Streets et al. (2003a) & 0.103 & & & & & & & & \\
\hline Ohara et al. (2007) & 0.164 & 0.160 & 0.153 & 0.152 & & & & & \\
\hline Zhang et al. (2009a) & & & & & & & 0.182 & & \\
\hline This work & 0.090 & 0.091 & 0.090 & 0.088 & 0.085 & 0.081 & 0.077 & 0.072 & 0.066 \\
\hline \multicolumn{10}{|c|}{ OC } \\
\hline Streets et al. (2003a) & 0.196 & & & & & & & & \\
\hline Ohara et al. (2007) & 0.241 & 0.238 & 0.206 & 0.206 & & & & & \\
\hline Zhang et al. (2009a) & & & & & & & 0.145 & & \\
\hline This work & 0.054 & 0.056 & 0.056 & 0.056 & 0.055 & 0.053 & 0.051 & 0.050 & 0.046 \\
\hline \multicolumn{10}{|l|}{ (b) Southeast Asia } \\
\hline & 2000 & 2001 & 2002 & 2003 & 2004 & 2005 & 2006 & 2007 & 2008 \\
\hline
\end{tabular}


Table 10. Continued.

\begin{tabular}{|c|c|c|c|c|c|c|c|c|c|}
\hline \multicolumn{10}{|c|}{$\mathrm{SO}_{2}$} \\
\hline Streets et al. (2003a) & 3.15 & & & & & & & & \\
\hline Ohara et al. (2007) & 3.65 & 3.85 & 3.83 & 3.81 & & & & & \\
\hline Zhang et al. (2009a) & & & & & & & 5.48 & & \\
\hline EDGAR 4.2 & 4.11 & 4.18 & 4.17 & 4.11 & 4.51 & 4.64 & 4.74 & 4.88 & 4.99 \\
\hline This work & 3.71 & 3.80 & 3.74 & 3.72 & 3.95 & 4.13 & 4.13 & 4.19 & 4.21 \\
\hline \multicolumn{10}{|c|}{$\mathrm{NO}_{\mathrm{x}}$} \\
\hline Streets et al. (2003a) & 3.06 & & & & & & & & \\
\hline Ohara et al. (2007) & 3.77 & 3.97 & 4.15 & 4.29 & & & & & \\
\hline Zhang et al. (2009a) & & & & & & & 5.51 & & \\
\hline EDGAR 4.2 & 3.29 & 3.41 & 3.42 & 3.46 & 3.71 & 3.76 & 3.74 & 3.88 & 3.84 \\
\hline This work & 3.00 & 3.13 & 3.24 & 3.33 & 3.62 & 3.89 & 4.15 & 4.70 & 4.97 \\
\hline \multicolumn{10}{|c|}{$\mathrm{CO}$} \\
\hline Streets et al. (2003a) & 34.0 & & & & & & & & \\
\hline Ohara et al. (2007) & 54.5 & 55.0 & 57.1 & 59.1 & & & & & \\
\hline Zhang et al. (2009a) & & & & & & & 44.6 & & \\
\hline EDGAR 4.2 & 32.7 & 32.9 & 31.5 & 31.5 & 32.7 & 32.8 & 32.7 & 32.8 & 32.4 \\
\hline This work & 36.2 & 36.8 & 37.8 & 39.1 & 40.7 & 42.1 & 43.8 & 46.5 & 48.3 \\
\hline \multicolumn{10}{|c|}{ NMVOC } \\
\hline Streets et al. (2003a) & 11.1 & & & & & & & & \\
\hline Ohara et al. (2007) & 11.1 & 11.3 & 11.9 & 12.4 & & & & & \\
\hline Zhang et al. (2009a) & & & & & & & 14.1 & & \\
\hline EDGAR 4.2 & 9.28 & 9.35 & 9.05 & 9.15 & 9.39 & 9.50 & 9.54 & 9.67 & 9.64 \\
\hline This work & 10.23 & 10.54 & 10.99 & 11.54 & 12.13 & 12.71 & 13.32 & 14.28 & 15.00 \\
\hline \multicolumn{10}{|c|}{$\mathrm{PM}_{10}$} \\
\hline Zhang et al. (2009a) & & & & & & & 4.15 & & \\
\hline EDGAR 4.2 & 3.50 & 3.58 & 3.43 & 3.47 & 3.25 & 3.31 & 3.41 & 3.48 & 3.49 \\
\hline This work & 2.78 & 2.83 & 2.89 & 2.88 & 2.87 & 2.86 & 2.93 & 3.07 & 3.09 \\
\hline \multicolumn{10}{|c|}{$\mathrm{PM}_{2.5}$} \\
\hline Zhang et al. (2009a) & & & & & & & 3.53 & & \\
\hline This work & 2.11 & 2.13 & 2.18 & 2.17 & 2.16 & 2.14 & 2.18 & 2.26 & 2.27 \\
\hline \multicolumn{10}{|c|}{$\mathrm{BC}$} \\
\hline Streets et al. (2003a) & 0.320 & & & & & & & & \\
\hline Ohara et al. (2007) & 0.413 & 0.419 & 0.430 & 0.436 & & & & & \\
\hline Zhang et al. (2009a) & & & & & & & 0.386 & & \\
\hline This work & 0.315 & 0.320 & 0.327 & 0.332 & 0.340 & 0.345 & 0.352 & 0.365 & 0.371 \\
\hline \multicolumn{10}{|c|}{ OC } \\
\hline Streets et al. (2003a) & 1.37 & & & & & & & & \\
\hline Ohara et al. (2007) & 1.83 & 1.85 & 1.90 & 1.92 & & & & & \\
\hline Zhang et al. (2009a) & & & & & & & 1.58 & & \\
\hline This work & 1.30 & 1.31 & 1.33 & 1.34 & 1.35 & 1.36 & 1.38 & 1.40 & 1.42 \\
\hline \multicolumn{10}{|c|}{ (c) South Asia outside India } \\
\hline & 2000 & 2001 & 2002 & 2003 & 2004 & 2005 & 2006 & 2007 & 2008 \\
\hline \multicolumn{10}{|c|}{$\mathrm{SO}_{2}$} \\
\hline Streets et al. (2003a) & 1.63 & & & & & & & & \\
\hline Ohara et al. (2007) & 1.34 & 1.36 & 1.36 & 1.28 & & & & & \\
\hline Zhang et al. (2009a) & & & & & & & 3.16 & & \\
\hline EDGAR 4.2 & 1.03 & 1.02 & 0.98 & 0.69 & 0.82 & 0.93 & 1.17 & 1.21 & 1.15 \\
\hline This work & 1.19 & 1.18 & 1.17 & 1.03 & 1.17 & 1.23 & 1.38 & 1.52 & 1.41 \\
\hline
\end{tabular}


Table 10. Continued.

\begin{tabular}{|c|c|c|c|c|c|c|c|c|c|}
\hline \multicolumn{10}{|c|}{$\mathrm{NO}_{\mathrm{x}}$} \\
\hline streets et al. (2003a) & 0.11 & & & & & & & & \\
\hline Ohara et al. (2007) & 0.99 & 1.02 & 1.03 & 1.07 & & & & & \\
\hline Zhang et al. (2009a) & & & & & & & 0.97 & & \\
\hline EDGAR 4.2 & 0.86 & 0.88 & 0.88 & 0.86 & 0.95 & 0.97 & 1.02 & 1.13 & 1.10 \\
\hline This work & 1.14 & 1.03 & 1.13 & 1.24 & 1.32 & 1.36 & 1.42 & 1.50 & 1.56 \\
\hline \multicolumn{10}{|c|}{$\mathrm{CO}$} \\
\hline Streets et al. (2003a) & 11.2 & & & & & & & & \\
\hline Ohara et al. (2007) & 19.1 & 19.5 & 19.9 & 20.6 & & & & & \\
\hline Zhang et al. (2009a) & & & & & & & 13.9 & & \\
\hline EDGAR 4.2 & 10.0 & 10.0 & 9.8 & 10.2 & 10.3 & 10.5 & 10.7 & 11.1 & 11.1 \\
\hline This work & 12.1 & 12.4 & 12.7 & 13.3 & 13.7 & 14.1 & 14.6 & 15.2 & 15.2 \\
\hline \multicolumn{10}{|c|}{ NMVOC } \\
\hline Streets et al. (2003a) & 2.04 & & & & & & & & \\
\hline Ohara et al. (2007) & 2.04 & 2.10 & 2.14 & 2.28 & & & & & \\
\hline Zhang et al. (2009a) & & & & & & & 2.60 & & \\
\hline EDGAR 4.2 & 2.58 & 2.59 & 2.55 & 2.61 & 2.65 & 2.71 & 2.75 & 2.83 & 2.86 \\
\hline This work & 2.87 & 2.94 & 3.04 & 3.19 & 3.29 & 3.39 & 3.49 & 3.61 & 3.71 \\
\hline \multicolumn{10}{|c|}{$\mathrm{PM}_{10}$} \\
\hline Zhang et al. (2009a) & & & & & & & 1.63 & & \\
\hline EDGAR 4.2 & 1.11 & 1.11 & 1.07 & 1.09 & 1.10 & 1.12 & 1.13 & 1.16 & 1.17 \\
\hline This work & 0.868 & 0.905 & 0.941 & 0.987 & 1.03 & 1.07 & 1.12 & 1.17 & 1.21 \\
\hline \multicolumn{10}{|c|}{$\mathrm{PM}_{2.5}$} \\
\hline Zhang et al. (2009a) & & & & & & & 1.43 & & \\
\hline This work & 0.792 & 0.811 & 0.839 & 0.873 & 0.903 & 0.931 & 0.964 & 0.995 & 1.02 \\
\hline \multicolumn{10}{|c|}{$\mathrm{BC}$} \\
\hline Streets et al. (2003a) & 0.142 & & & & & & & & \\
\hline Ohara et al. (2007) & 0.234 & 0.239 & 0.243 & 0.246 & & & & & \\
\hline Zhang et al. (2009a) & & & & & & & 0.191 & & \\
\hline This work & 0.158 & 0.155 & 0.161 & 0.169 & 0.173 & 0.178 & 0.181 & 0.186 & 0.192 \\
\hline \multicolumn{10}{|c|}{ OC } \\
\hline Streets et al. (2003a) & 0.626 & & & & & & & & \\
\hline Ohara et al. (2007) & 0.967 & 0.986 & 1.007 & 1.025 & & & & & \\
\hline Zhang et al. (2009a) & & & & & & & 0.707 & & \\
\hline This work & 0.565 & 0.571 & 0.587 & 0.603 & 0.618 & 0.632 & 0.647 & 0.660 & 0.674 \\
\hline
\end{tabular}

Lu et al. (2011) (about $31 \%$ ). For OC, emissions estimated by Rv2 were within $5 \%$ of those in Lu et al. (2011) during 2000 and 2008. OC emissions of Bond et al. (2007) and Zhang et al. (2009a) are much smaller, but those of Streets et al. (2003a) are larger than Rv2 for India. Emissions of BC in Bond et al. (2007) and those of OC in Klimont et al. (2009) were agreed well with in Rv2.

Table 10 presents emissions from Rv2 and other inventories for OEA, SEA, and OSA. For OEA, the $\mathrm{SO}_{2}, \mathrm{CO}$, and NMVOC emissions of both Rv2 and EDGAR decrease from 2000 to 2008, the decrease in EDGAR is much greater than in Rv2. Net emission factors, including removal effi- ciencies, are thought to be much higher in EDGAR than in Rv2, whose emissions for Japan, South Korea, and Taiwan are obtained from detailed studies (see Sect. 2.5). Results of Rv2 for these species generally agree with Streets et al. (2003a) and Zhang et al. (2009a). Differences in $\mathrm{NO}_{\mathrm{x}}$ emissions between Rv2 and other inventories are relatively small. Emissions of $\mathrm{PM}_{10}$ and $\mathrm{PM}_{2.5}$ in Rv2 were smaller than in Zhang et al. (2009a) and EDGAR. Large differences in BC emissions between Rv2 and Zhang et al. (2009a) are due to estimations for Taiwan. OC emissions of Rv2 are much smaller than those in Streets et al. (2003a) and Zhang et al. (2009a) because Rv2 has lower estimated emissions for 
North Korea. For SEA, results in Rv2 generally agree with Streets et al. (2003a) and Zhang et al. (2009a) within $15 \%$ except that the $\mathrm{SO}_{2}$ and $\mathrm{NO}_{\mathrm{x}}$ emissions for 2006 of Zhang et al. (2009a) are about $30 \%$ larger than those in Rv2. Emissions of $\mathrm{SO}_{2}, \mathrm{NO}_{\mathrm{x}}, \mathrm{CO}$, and NMVOC in Rv2 agree with those in EDGAR within $10 \%$ for $2000 . \mathrm{SO}_{2}$ emissions between 2000 and 2008 show similar trends in EDGAR and Rv2, but growth rates for other species were much larger for Rv2. $\mathrm{PM}_{10}$ emissions of Rv2 generally agreed well with those of EDGAR within 10-25\%, but smaller than those of Zhang et al. (2009a) by about $40 \%$. With respect to OSA, emissions of Rv2 are larger than those of EDGAR for all species except for $\mathrm{PM}_{10}$. In general, however, their trends are similar, especially for $\mathrm{SO}_{2}$, although growth rates between 2000 and 2008 for $\mathrm{NO}_{\mathrm{x}}, \mathrm{CO}$, and NMVOC in Rv2 are slightly larger than in EDGAR. For $\mathrm{PM}_{10}$, emissions of Rv2 increased about $40 \%$ from 2000 to 2008, but those of EDGAR were almost constant during the same period. Compared to Streets et al. (2003a) and Zhang et al. (2009a), emissions in $\mathrm{Rv} 2$ are much smaller for $\mathrm{SO}_{2}, \mathrm{PM}_{10}$, and $\mathrm{PM}_{2.5}$ but larger for $\mathrm{NO}_{\mathrm{x}}$ and NMVOC. However, $\mathrm{CO}, \mathrm{BC}$, and $\mathrm{OC}$ emissions are generally consistent in all inventories.

Table 11 presents $\mathrm{NH}_{3}, \mathrm{CH}_{4}$, and $\mathrm{N}_{2} \mathrm{O}$ emissions estimated by Rv2 and other inventories for China, India, and other parts of Asia (OA) which exclude RCA. The $\mathrm{NH}_{3}$ and $\mathrm{N}_{2} \mathrm{O}$ emissions in Rv2 are much larger than those in EDGAR, result arising from differences in agricultural emissions related to manure management and agricultural soil. Similarly, $\mathrm{NH}_{3}$ emissions of China in Rv2 were much larger than in Huang et al. (2012) due to the differences in emissions from fertilizer application. Differences in $\mathrm{NH}_{3}$ emissions between Rv2 and Streets et al. (2003a) are relatively small, about $6 \%, 11 \%$, and $16 \%$ for China, India, and OA, respectively. With respect to $\mathrm{CH}_{4}, \mathrm{Rv} 2$ and EDGAR agree very well in their amounts of emissions and year-to-year variations. However, differences of $\mathrm{CH}_{4}$ emissions between Rv2 and Streets et al. (2003a) are larger than those of $\mathrm{NH}_{3}$. $\mathrm{CH}_{4}$ emissions of Rv2 in China and OA are about $29 \%$ and $13 \%$ larger than, respectively, than those in Streets et al. (2003a), and those in India are about $16 \%$ smaller. For $\mathrm{CO}_{2}$, emissions in Rv2, Boden et al. (2013), and EDGAR show generally similar values and trends compared to other species. $\mathrm{CO}_{2}$ emissions of China in Rv2 were relatively larger than in Boden et al. (2013) and EDGAR.

Table 12 compares the emissions of major air pollutants estimated by Rv2 with those by other regional inventories. Zhao et al. (2012) estimated emissions in Huabei region, which include Beijing, Tianjin, Hebei, Shanxi, Inner Mongolia, Shandong, Henan, and Liaoning provinces. For $\mathrm{SO}_{2}$, $\mathrm{NO}_{\mathrm{x}}, \mathrm{CO}$, and $\mathrm{NMVOC}$, emissions in Rv2 are mostly larger than in Zhao et al. (2012). Differences of $\mathrm{SO}_{2}$ and $\mathrm{CO}$ were within $30 \%$ for all provinces but those of NMVOC were more than $30 \%$ except for Liaoning. For $\mathrm{NO}_{\mathrm{x}}$ emissions, emissions in Rv2 were within $20 \%$ of those in Zhao et al. (2012) except for Tianjin, Inner Mongolia, and Liaon- ing. For $\mathrm{PM}$, emissions of $\mathrm{PM}_{10}$ and $\mathrm{PM}_{2.5}$ in $\mathrm{Rv} 2$ are much higher than in Zhao et al. (2012) for Inner Mongolia, Shandon, Henan, and Liaoning province, but those of BC and $\mathrm{OC}$ were relatively agreed well. $\mathrm{NH}_{3}$ emissions in $\mathrm{Rv} 2$ were larger than in Zhao et al. (2012) for all provinces but those for Beijing, Tianjin, and Inner Mongolia were within $15 \%$. Huang et al. (2011) estimated emissions in the Yangtze River Delta region, which include Shanghai and parts of Jiangsu and Zhejiang provinces. Emissions in Rv2 for parts of Jiangsu and Zhejiang were obtained from gridded data. Emissions for Shanghai in Rv2 are much higher than in Huang et al. (2011) except for $\mathrm{PM}_{10}$. Their differences were more than $40 \%$. For parts of Jiangsu and Zhejiang, $\mathrm{SO}_{2}$ and $\mathrm{NO}_{\mathrm{x}}$ emissions in Jiangsu and those of $\mathrm{NO}_{\mathrm{x}}$ in Zhejiang were agreed very well between Rv2 and Huang et al. (2011). However, in general, there are large discrepancies for other species. Emissions of $\mathrm{CO}, \mathrm{NMVOC}$, and $\mathrm{NH}_{3}$ in Rv2 were much higher and those of $\mathrm{PM}_{10}$ and $\mathrm{PM}_{2.5}$ were much lower than in Huang et al. (2011). Zheng et al. (2009) estimated emissions in the Pearl River Delta region which include part of Guangdong province. Emissions of $\mathrm{SO}_{2}, \mathrm{NO}_{\mathrm{x}}, \mathrm{CO}$, and $\mathrm{PM}_{10}$ in Rv2 agreed well with those in Zheng et al. (2009) within about $25 \%$. NMVOC and $\mathrm{PM}_{2.5}$ emissions in Rv2 were about $35 \%$ larger than in Zheng et al. (2009). Gurjar et al. (2004) estimated emissions in Delhi, India. Emissions of $\mathrm{NO}_{\mathrm{x}}, \mathrm{CO}$, and $\mathrm{NMVOC}$ in Rv2 were agreed very well with those in Gurjar (2004) within $5 \%$ and difference of $\mathrm{CO}_{2}$ emissions was also relatively small. However, Rv2 emissions of $\mathrm{NH}_{3}$ and $\mathrm{N}_{2} \mathrm{O}$ were much higher and those of $\mathrm{SO}_{2}$ and $\mathrm{CH}_{4}$ were much lower than emissions in Gurjar et al. (2004), respectively.

\subsection{Uncertainty}

In REAS 2.1, country and regional emissions were calculated using activity data, emission factors and removal efficiencies. Uncertainties of emissions are determined by the accuracy of these parameters and vary by emission sources, countries, and species. In this study, we estimated the uncertainties of emissions in REAS 2.1 after Streets et al. (2003) and Huang et al. (2011). First, the accuracy of activity data such as fuel consumption and commodity production, and emission factors including removal efficiencies was estimated. As Streets et al. (2003) indicated, there is no way to judge the accuracy of activity estimates. In addition, even though emission factors were based on detailed experiments, inevitable uncertainties are added when representative values are selected for specific emission sources, countries and regions. It is fundamentally difficult to quantify these uncertainties. Therefore, in this study, coefficient of variations for both activity data and emission factors were estimated based on expert judgment in the rage of 10-200\%. For combining uncertainties, we assumed that activity data and emission factors are independent and the relative $95 \%$ confidence intervals of emissions are calculated as 1.96 times the coefficient of variation. 
If the same emission factors were used for some sectors or countries and regions, their uncertainties were added linearly. Then, independent uncertainties are combined in quadrature (Streets et al., 2003).

Table 13 presents the estimated uncertainties of emissions by sectors in China, India, and the rest of Asian countries. Uncertainties of total emissions in China/India/the rest of Asian countries are as follows: $\pm 31 / 32 / 35 \%$ for $\mathrm{SO}_{2}, \pm 37 / 49 / 47 \%$ for $\mathrm{NO}_{\mathrm{x}}, \pm 86 / 114 / 131 \%$ for CO, $\pm 78 / 137 / 111 \%$ for NMVOC, $\pm 114 / 120 / 194 \%$ for $\mathrm{PM}_{10}, \pm 133 / 145 / 208 \%$ for $\mathrm{PM}_{2.5}, \pm 176 / 178 / 257 \%$ for BC, $\pm 271 / 233 / 286 \%$ for OC, $\pm 153 / 144 / 148 \%$ for $\mathrm{NH}_{3}$, $\pm 211 / 154 / 204 \%$ for $\mathrm{CH}_{4}, \pm 130 / 153 / 135 \%$ for $\mathrm{N}_{2} \mathrm{O}$, and $\pm 31 / 49 / 44 \%$ for $\mathrm{CO}_{2}$. Generally, uncertainties of $\mathrm{SO}_{2}$, $\mathrm{NO}_{\mathrm{x}}$, and $\mathrm{CO}_{2}$ emissions whose major sources are complete combustion are relatively small, whereas those of $\mathrm{CO}$ and PM basically from imperfect combustion are relatively large. For NMVOC, uncertainties for fossil fuel combustion sources are relatively small, but those for biofuel combustion and evaporative emissions are large. Note that emissions obtained from other research works were not taken into considered for the calculation of uncertainties, such as most of anthropogenic emissions for Japan, South Korea, and Taiwan and agricultural emissions from livestock and fertilizer application (see footnote in Table 13). As the emissions in Japan, South Korea, and Taiwan were developed based on detailed information for activity data and parameters as described in Sect 2.5, uncertainties of these emissions are expected to be small. For $\mathrm{NH}_{3}, \mathrm{CH}_{4}$, and $\mathrm{N}_{2} \mathrm{O}$, as described in Sect. 2.2.3, the agricultural emission data were extrapolated from the gridded data of REAS 1.1 for 2000. Therefore, uncertainties of the agricultural emissions for these species are considered to be large.

For activity data of stationary sources, we relied on international, national, and regional statistics. Uncertainties in fossil fuel consumption and production of major industrial commodities such as metal and cement are expected to be small because they are basic statistics for each country. In addition, as described in Sect. 2.3, we updated the database for power plants as point sources with detailed information. Therefore, uncertainties of emissions from power plants are smaller than those from other sources although there are still certain uncertainties as mentioned in Sect. 2.5. On the other hand, consumption of biofuels in IEA statistics is the sum of several fuels such as fuel wood, crop residue, and animal waste. We distributed the data to each fuel type referring limited information such as Streets et al. (1998) and the database of the GAINS model. Therefore, uncertainties of biofuel consumption are larger than those of fossil fuels. This is one of major reasons for large uncertainties in primary aerosol emissions, especially OC. For industrial production, information for brick production in Asia is not enough. UNEP (2011) indicated that brick kiln is one of major sources to reduce $\mathrm{BC}$ emissions for mitigating near-term climate change and improving air quality at the same time. Therefore further survey of emissions from brick production is required to improve the accuracy of $\mathrm{BC}$ emissions especially for the support of policy-making. For road transport sector, number of vehicles and average annual distance traveled for China were updated by new information as described in Sect. 2.2.2. Therefore, uncertainties for road transport emissions in China are smaller compared to those in other countries and regions. In Asia, number of vehicles is still increasing and thus, reducing uncertainties of road transport emissions is an important task for next version of REAS.

For emission factors and removal efficiencies, we updated the parameters using recently published literatures for Asian emission inventory, especially for China (see Sect. 2.4). Therefore, the uncertainties of emissions in China are generally smaller than other countries and regions. On the other hand, information for country- and region-specific emission factors is not enough especially for Southeast and South Asian countries. Further investigations of literatures and collaborative studies with researchers in these countries are essential to reduce the uncertainties of Asian emission inventory.

REAS 2.1 improved both spatial and temporal resolution. For large power plants, we updated not only position data but also start and retired year. In addition, we obtained statistics for monthly generated power in China, India, and Vietnam. Accuracy of monthly gridded data for power plants was increased from REAS 1.1. We also updated population distribution data for finer resolution and monthly variation of emissions from heating stoves is considered using objective analysis meteorological data. Therefore, uncertainty of monthly gridded emission data for residential sector was also reduced. For industry sector, monthly productions of major commodities were collected. In addition, we developed surrogate data to allocate emissions from iron, steel, and cement productions. These updates improved the accuracy of industrial emissions compared to REAS 1.1. However, we could not obtain enough information for large industrial plants to be treated as point sources. For transport sector, we could not update both proxy data for grid allocation and monthly variation of emissions. Improvements of accuracy for spatial distribution and temporal variation for industry and road transport sectors are also major issues for the next version of REAS.

\subsection{Data distribution}

We have prepared a data download site for REAS 2.1 at the following URL: http://www.nies.go.jp/REAS/. Monthly gridded emission data sets at $0.25^{\circ} \times 0.25^{\circ}$ resolution for each major sector can be downloaded for all species. As was true for REAS version 1, NMVOC emissions are speciated to 19 species (ethane, propane, butanes, pentanes, other alkanes, ethylene, propene, terminal alkenes, internal alkenes, acetylene, benzene, toluene, xylenes, other aromatics, formaldehyde, other aldehyde, ketones, halocarbons, and 
Table 11. Published estimates of $\mathrm{NH}_{3}, \mathrm{CH}_{4}, \mathrm{~N}_{2} \mathrm{O}$, and $\mathrm{CO}_{2}$ emissions from China, India, and the rest of the Asian countries (Tg yr ${ }^{-1}$ ).

\begin{tabular}{|c|c|c|c|c|c|c|c|c|c|}
\hline & 2000 & 2001 & 2002 & 2003 & 2004 & 2005 & 2006 & 2007 & 2008 \\
\hline \multicolumn{10}{|c|}{$\mathrm{NH}_{3}$} \\
\hline \multicolumn{10}{|l|}{ China } \\
\hline Streets et al. (2003a) & 13.3 & & & & & & & & \\
\hline Ohara et al. (2007) & 12.6 & 12.6 & 12.6 & 12.6 & & & & & \\
\hline Huang et al. (2012) & & & & & & & 9.71 & & \\
\hline EDGAR 4.2 & 8.7 & 8.8 & 9.6 & 9.4 & 10.1 & 10.2 & 10.6 & 10.9 & 11.2 \\
\hline This work & 12.5 & 12.6 & 13.6 & 13.4 & 13.1 & 13.6 & 14.3 & 14.6 & 14.8 \\
\hline \multicolumn{10}{|l|}{ India } \\
\hline Streets et al. (2003a) & 7.23 & & & & & & & & \\
\hline Ohara et al. (2007) & 8.48 & 8.52 & 8.56 & 8.60 & & & & & \\
\hline EDGAR 4.2 & 3.86 & 3.96 & 3.79 & 3.96 & 4.08 & 4.08 & 4.15 & 4.19 & 4.24 \\
\hline This work & 8.08 & 8.21 & 8.04 & 8.23 & 8.44 & 8.71 & 9.02 & 9.25 & 9.42 \\
\hline \multicolumn{10}{|l|}{ Other Asia } \\
\hline Streets et al. (2003a) & 6.03 & & & & & & & & \\
\hline Ohara et al. (2007) & 7.02 & 7.08 & 7.14 & 7.20 & & & & & \\
\hline EDGAR 4.2 & 4.06 & 4.02 & 4.24 & 4.31 & 4.38 & 4.46 & 4.54 & 4.63 & 4.70 \\
\hline This work & 7.16 & 7.18 & 7.42 & 7.62 & 7.92 & 7.89 & 8.04 & 8.28 & 8.34 \\
\hline \multicolumn{10}{|c|}{$\mathrm{CH}_{4}$} \\
\hline \multicolumn{10}{|l|}{ China } \\
\hline Streets et al. (2003a) & 37.8 & & & & & & & & \\
\hline Ohara et al. (2007) & 33.1 & 33.1 & 33.1 & 33.2 & & & & & \\
\hline EDGAR 4.2 & 49.8 & 50.2 & 51.8 & 54.7 & 59.7 & 63.3 & 66.4 & 68.9 & 73.3 \\
\hline This work & 48.8 & 49.9 & 53.4 & 58.0 & 62.4 & 66.9 & 69.2 & 70.9 & 76.0 \\
\hline \multicolumn{10}{|l|}{ India } \\
\hline Streets et al. (2003a) & 32.4 & & & & & & & & \\
\hline Ohara et al. (2007) & 25.7 & 25.8 & 25.8 & 25.9 & & & & & \\
\hline EDGAR 4.2 & 26.4 & 26.7 & 26.7 & 27.1 & 27.2 & 27.6 & 27.8 & 28.2 & 28.6 \\
\hline This work & 27.3 & 27.3 & 27.0 & 27.3 & 27.3 & 27.5 & 28.8 & 28.4 & 29.4 \\
\hline \multicolumn{10}{|l|}{ Other Asia } \\
\hline Streets et al. (2003a) & 33.5 & & & & & & & & \\
\hline Ohara et al. (2007) & 31.1 & 31.1 & 31.2 & 31.2 & & & & & \\
\hline EDGAR 4.2 & 39.4 & 39.8 & 40.6 & 41.5 & 42.5 & 43.8 & 45.1 & 46.2 & 47.1 \\
\hline This work & 38.0 & 38.1 & 38.7 & 39.4 & 40.3 & 41.6 & 42.8 & 43.5 & 44.4 \\
\hline \multicolumn{10}{|c|}{$\mathrm{N}_{2} \mathrm{O}$} \\
\hline \multicolumn{10}{|l|}{ China } \\
\hline EDGAR 4.2 & 1.38 & 1.40 & 1.50 & 1.51 & 1.59 & 1.63 & 1.69 & 1.73 & 1.76 \\
\hline This work & 2.16 & 2.18 & 2.31 & 2.30 & 2.31 & 2.41 & 2.55 & 2.59 & 2.66 \\
\hline \multicolumn{10}{|l|}{ India } \\
\hline EDGAR 4.2 & 0.68 & 0.69 & 0.68 & 0.70 & 0.72 & 0.72 & 0.73 & 0.75 & 0.76 \\
\hline This work & 1.51 & 1.53 & 1.48 & 1.52 & 1.54 & 1.59 & 1.65 & 1.70 & 1.72 \\
\hline \multicolumn{10}{|l|}{ Other Asia } \\
\hline EDGAR 4.2 & 0.82 & 0.85 & 0.91 & 0.83 & 0.88 & 0.91 & 1.03 & 0.87 & 0.86 \\
\hline This work & 1.22 & 1.22 & 1.24 & 1.26 & 1.32 & 1.31 & 1.35 & 1.36 & 1.37 \\
\hline
\end{tabular}


Table 11. Continued.

\begin{tabular}{lccccccccc}
\hline \multicolumn{1}{c}{$\mathrm{CO}_{2}$ (fossil fuel combustion and industrial process) } \\
\hline China & & & & & & & & & \\
\hline Boden et al. (2013) & 3405 & 3487 & 3694 & 4525 & 5288 & 5789 & 6414 & 6791 & 7035 \\
EDGAR 4.2 & 3530 & 3602 & 3860 & 4465 & 5238 & 5811 & 6463 & 6966 & 7742 \\
This work & 3702 & 3815 & 4147 & 4691 & 5345 & 6291 & 6977 & 7739 & 8155 \\
\hline India & & & & & & & & & \\
\hline Boden et al. (2013) & 1183 & 1201 & 1224 & 1280 & 1347 & 1409 & 1502 & 1609 & 1809 \\
EDGAR 4.2 & 1026 & 1043 & 1088 & 1118 & 1207 & 1253 & 1347 & 1443 & 1528 \\
This work & 1032 & 1050 & 1083 & 1110 & 1188 & 1243 & 1337 & 1430 & 1535 \\
\hline Other Asia & & & & & & & & & \\
\hline Boden et al. (2013) & 3170 & 3254 & 3342 & 3424 & 3581 & 3563 & 3619 & 3783 & 3815 \\
EDGAR 4.2 & 3159 & 3218 & 3316 & 3408 & 3534 & 3604 & 3669 & 3789 & 3778 \\
This work & 3086 & 3151 & 3234 & 3332 & 3454 & 3492 & 3571 & 3687 & 3682 \\
\hline
\end{tabular}

Table 12. Comparison with regional emission inventories of provinces in China and Delhi, $\operatorname{India}\left(\mathrm{Tg} \mathrm{yr}^{-1}\right)$. Values before and after slash are results of other published works and REAS 2.1, respectively.

\begin{tabular}{|c|c|c|c|c|c|c|c|c|c|}
\hline & $\mathrm{SO}_{2}$ & $\mathrm{NO}_{\mathrm{x}}$ & $\mathrm{CO}$ & NMVOC & $\mathrm{PM}_{10}$ & $\mathrm{PM}_{2.5}$ & $\mathrm{BC}$ & $\mathrm{OC}$ & $\mathrm{NH}_{3}$ \\
\hline \multicolumn{10}{|l|}{ Zhao et al. (2012) ${ }^{\mathrm{a}}$} \\
\hline Beijing & $0.187 / 0.264$ & $0.309 / 0.267$ & $2.58 / 3.22$ & $0.346 / 0.627$ & $0.168 / 0.238$ & $0.090 / 0.143$ & $0.025 / 0.020$ & $0.026 / 0.027$ & $0.087 / 0.076$ \\
\hline Tianjin & $0.259 / 0.355$ & $0.177 / 0.270$ & $1.33 / 1.60$ & $0.224 / 0.338$ & $0.186 / 0.165$ & $0.100 / 0.105$ & $0.010 / 0.013$ & $0.021 / 0.017$ & $0.074 / 0.065$ \\
\hline Hebei & $1.62 / 2.20$ & $1.09 / 1.05$ & $12.2 / 16.8$ & $0.757 / 1.07$ & $2.29 / 1.20$ & $1.21 / 0.841$ & $0.080 / 0.100$ & $0.212 / 0.207$ & $1.03 / 0.755$ \\
\hline Shanxi & $2.06 / 1.66$ & $0.807 / 0.772$ & $5.37 / 5.37$ & $0.224 / 0.462$ & $0.981 / 0.947$ & $0.524 / 0.628$ & $0.066 / 0.109$ & $0.129 / 0.154$ & $0.347 / 0.225$ \\
\hline Inner Mongolia & $0.608 / 0.763$ & $0.331 / 0.577$ & $2.67 / 3.62$ & $0.219 / 0.376$ & $0.946 / 0.393$ & $0.490 / 0.291$ & $0.029 / 0.037$ & $0.070 / 0.082$ & $0.493 / 0.427$ \\
\hline Shandong & $2.46 / 2.97$ & $1.11 / 1.27$ & $10.1 / 13.8$ & $0.925 / 1.59$ & $2.68 / 1.24$ & $1.39 / 0.816$ & $0.084 / 0.078$ & $0.241 / 0.174$ & $1.34 / 1.05$ \\
\hline Henan & $1.34 / 1.45$ & $0.874 / 0.874$ & $6.95 / 6.44$ & $0.643 / 0.986$ & $2.28 / 1.06$ & $1.20 / 0.668$ & $0.075 / 0.061$ & $0.188 / 0.132$ & $1.47 / 1.08$ \\
\hline Liaoning & $1.03 / 1.19$ & $0.574 / 0.795$ & $5.40 / 6.49$ & $0.486 / 0.632$ & $1.20 / 0.733$ & $0.621 / 0.521$ & $0.044 / 0.057$ & $0.103 / 0.114$ & $0.508 / 0.392$ \\
\hline \multicolumn{10}{|l|}{ Huang et al. (2011) ${ }^{\mathrm{b}}$} \\
\hline Part of Jiangsu & $1.24 / 1.18$ & $1.14 / 1.14$ & $3.64 / 10.2$ & $1.16 / 2.02$ & $1.67 / 0.890$ & $0.837 / 0.591$ & & & $0.263 / 0.487$ \\
\hline Part of Zhejiang & $0.751 / 0.544$ & $0.769 / 0.691$ & $1.50 / 4.60$ & $1.02 / 1.23$ & $1.18 / 0.442$ & $0.554 / 0.258$ & & & $0.154 / 0.215$ \\
\hline Shanghai & $0.399 / 0.894$ & $0.380 / 0.912$ & $1.56 / 4.08$ & $0.587 / 1.31$ & $0.266 / 0.329$ & $0.119 / 0.200$ & & & $0.043 / 0.088$ \\
\hline \multicolumn{10}{|l|}{ Zheng et al. (2009) ${ }^{\mathrm{c}}$} \\
\hline \multirow[t]{2}{*}{ Part of Guangdong } & $0.711 / 0.900$ & $0.884 / 0.727$ & $3.77 / 4.01$ & $0.865 / 1.29$ & $0.411 / 0.512$ & $0.202 / 0.325$ & & & \\
\hline & $\mathrm{SO}_{2}$ & $\mathrm{NO}_{\mathrm{x}}$ & $\mathrm{CO}$ & NMVOC & $\mathrm{NH}_{3}$ & $\mathrm{CH}_{4}$ & $\mathrm{~N}_{2} \mathrm{O}$ & $\mathrm{CO}_{2}$ & \\
\hline \multicolumn{10}{|l|}{ Gurjar et al. (2004) } \\
\hline Delhi & $0.102 / 0.071$ & $0.161 / 0.153$ & $0.503 / 0.481$ & $0.212 / 0.210$ & $0.010 / 0.032$ & $0.192 / 0.078$ & $1.65 / 4.6$ & $22.0 / 19.1$ & \\
\hline
\end{tabular}

a Base year is 2003 .

${ }^{\mathrm{b}}$ Base year is 2007 .

${ }^{\mathrm{c}}$ Base year is 2006

d Base year is 2000 .

others). We also provide country and regional emission tables that present annual emissions for detailed sub-sectors and fuel types.

\section{Summary}

We developed a Regional Emission inventory in ASia (REAS) 2.1 by updating REAS 1.1 of Ohara et al. (2007). The new inventory includes most major air pollutants and greenhouse gases: $\mathrm{SO}_{2}, \mathrm{NO}_{\mathrm{x}}, \mathrm{CO}, \mathrm{NMVOC}, \mathrm{PM}_{10}, \mathrm{PM}_{2.5}$, $\mathrm{BC}, \mathrm{OC}, \mathrm{NH}_{3}, \mathrm{CH}_{4}, \mathrm{~N}_{2} \mathrm{O}$, and $\mathrm{CO}_{2}$. The target years are from 2000 to 2008, and areas have been expanded from East, Southeast and South Asia to encompass Central Asia and Asian Russia (Ural, Western and Eastern Siberia, and Far East). Emissions are estimated for each country and region and are allocated to grids at a $0.25^{\circ} \times 0.25^{\circ}$ resolution with monthly variation. Activity data such as energy consumption and industrial production were obtained in many cases 
Table 13. Uncertainties [\%] of emissions in China, India, and the rest of Asian countries*.

\begin{tabular}{|c|c|c|c|c|c|c|c|c|c|}
\hline & $\mathrm{SO}_{2}$ & $\mathrm{NO}$ & $\mathrm{CO}$ & NMV & $\mathrm{PM}_{10}$ & $\mathrm{PM}_{2.5}$ & $\mathrm{BC}$ & $\mathrm{OC}$ & $\mathrm{CO}_{2}$ \\
\hline \multicolumn{10}{|l|}{ China } \\
\hline Power plants & \pm 41 & \pm 68 & \pm 55 & \pm 51 & \pm 92 & \pm 91 & \pm 77 & \pm 69 & \pm 48 \\
\hline Industry & \pm 50 & \pm 60 & \pm 123 & \pm 118 & \pm 146 & \pm 169 & \pm 172 & \pm 207 & \pm 33 \\
\hline Road & \pm 43 & \pm 48 & \pm 59 & \pm 90 & \pm 89 & \pm 89 & \pm 111 & \pm 121 & \pm 31 \\
\hline Other transport & \pm 59 & \pm 86 & \pm 133 & \pm 114 & \pm 185 & \pm 168 & \pm 197 & \pm 190 & \pm 52 \\
\hline Domestic & \pm 60 & \pm 99 & \pm 174 & \pm 229 & \pm 244 & \pm 257 & \pm 297 & \pm 316 & \pm 103 \\
\hline Solvent use & 0 & 0 & 0 & \pm 127 & 0 & 0 & 0 & 0 & 0 \\
\hline Total & \pm 31 & \pm 37 & \pm 86 & \pm 78 & \pm 114 & \pm 133 & \pm 176 & \pm 271 & \pm 31 \\
\hline \multicolumn{10}{|l|}{ India } \\
\hline Power plants & \pm 46 & \pm 72 & \pm 51 & \pm 80 & \pm 88 & \pm 86 & \pm 86 & \pm 93 & \pm 42 \\
\hline Industry & \pm 43 & \pm 64 & \pm 118 & \pm 202 & \pm 180 & \pm 201 & \pm 259 & \pm 304 & \pm 46 \\
\hline Road & \pm 40 & \pm 68 & \pm 83 & \pm 142 & \pm 94 & \pm 94 & \pm 116 & \pm 104 & \pm 34 \\
\hline Other transport & \pm 51 & \pm 91 & \pm 126 & \pm 144 & \pm 187 & \pm 189 & \pm 229 & \pm 242 & \pm 56 \\
\hline Domestic & \pm 66 & \pm 179 & \pm 192 & \pm 248 & \pm 255 & \pm 259 & \pm 300 & \pm 304 & \pm 134 \\
\hline Solvent use & 0 & 0 & 0 & \pm 150 & 0 & 0 & 0 & 0 & 0 \\
\hline Total & \pm 32 & \pm 49 & \pm 114 & \pm 137 & \pm 120 & \pm 145 & \pm 178 & \pm 233 & \pm 49 \\
\hline \multicolumn{10}{|l|}{ Others } \\
\hline Power plants & \pm 47 & \pm 63 & \pm 104 & \pm 76 & \pm 65 & \pm 67 & \pm 114 & \pm 135 & \pm 35 \\
\hline Industry & \pm 51 & \pm 64 & \pm 167 & \pm 157 & \pm 222 & \pm 217 & \pm 235 & \pm 268 & \pm 41 \\
\hline Road & \pm 52 & \pm 69 & \pm 103 & \pm 119 & \pm 100 & \pm 100 & \pm 134 & \pm 126 & \pm 35 \\
\hline Other transport & \pm 63 & \pm 91 & \pm 126 & \pm 140 & \pm 185 & \pm 187 & \pm 222 & \pm 221 & \pm 69 \\
\hline Domestic & \pm 80 & \pm 163 & \pm 208 & \pm 257 & \pm 302 & \pm 304 & \pm 351 & \pm 354 & \pm 125 \\
\hline Solvent use & 0 & 0 & 0 & \pm 154 & 0 & 0 & 0 & 0 & 0 \\
\hline \multirow[t]{2}{*}{ Total } & \pm 35 & \pm 47 & \pm 131 & \pm 111 & \pm 194 & \pm 208 & \pm 257 & \pm 286 & \pm 44 \\
\hline & $\mathrm{NH}_{3}$ & $\mathrm{CH}_{4}$ & $\mathrm{~N}_{2} \mathrm{O}$ & & & & & & \\
\hline \multicolumn{10}{|l|}{ China } \\
\hline Total & \pm 153 & \pm 211 & \pm 130 & & & & & & \\
\hline \multicolumn{10}{|l|}{ India } \\
\hline Total & \pm 144 & \pm 154 & \pm 153 & & & & & & \\
\hline \multicolumn{10}{|l|}{ Others } \\
\hline Total & \pm 148 & \pm 204 & \pm 135 & & & & & & \\
\hline
\end{tabular}

from new statistics and the database of power plants as point sources was fully updated. We collected country- and regionspecific parameters such as emission factors and removal efficiencies from recently published studies. For Japan, South Korea, and Taiwan, we used the newest available national inventories based on detailed activity data and information (JPEC, 2012a, b, c; OPRF, 2012; Lee et al., 2011; Environmental Protection Administration of Taiwan).

Emissions from all of Asia for each species in 2008 (growth rate from 2000 to 2008$)$ were $56.9 \mathrm{Tg}(+34 \%)$ for $\mathrm{SO}_{2}, 53.9 \mathrm{Tg}(+54 \%)$ for $\mathrm{NO}_{\mathrm{x}}, 359.5 \mathrm{Tg}(+34 \%)$ for $\mathrm{CO}, 68.5 \mathrm{Tg}(+46 \%)$ for NMVOC, $32.8 \mathrm{Tg}(+17 \%)$ for $\mathrm{NH}_{3}, 36.4 \mathrm{Tg}(+45 \%)$ for $\mathrm{PM}_{10}, 24.7 \mathrm{Tg}(+42 \%)$ for $\mathrm{PM}_{2.5}$, $3.03 \mathrm{Tg}(+35 \%)$ for $\mathrm{BC}, 7.72 \mathrm{Tg}(+21 \%)$ for OC, $182.2 \mathrm{Tg}$
(+32\%) for $\mathrm{CH}_{4}, 5.80 \mathrm{Tg}(+18 \%)$ for $\mathrm{N}_{2} \mathrm{O}$, and $16.0 \mathrm{Pg}$ $(+57 \%)$ for $\mathrm{CO}_{2}$. For all species, China was the largest contributor to Asian emissions, and its growth rates in emissions were also the largest because of the continuous increase in its energy consumption, economic activities, and infrastructural development. Emission mitigation measures were implemented gradually in China during the target years in REAS 2.1. $\mathrm{SO}_{2}$ emissions in China increased from 2000 to 2006 and then decreased because of increasing penetration of FGD to large power plants. New vehicle emission standards are also becoming effective against $\mathrm{NO}_{\mathrm{x}}, \mathrm{CO}$, NMVOC, and primary aerosol emissions. However, emissions of these species in China still increased monotonically, and growth rates were large from 2000 to 2008 . The 
second largest contributor to Asian emissions was India, and its emissions also grew rapidly from 2000 to 2008. This is because consumption of fossil fuels and biofuels, industrial production, and the number of vehicles were increasing rapidly while emission regulation measures in India were assumed to be limited. Emissions of air pollutants in East Asia outside China decreased from 2000 to 2008. This region's emissions were dominated by Japan, South Korea, and Taiwan, where economic growth rates are smaller than China and India and regulation of emissions has become more effective since 2000. Although the proportional contributions of other regions in Asia are small compared to China and India, emissions in Southeast Asia, South Asia outside India, Central Asia, and Asian Russia generally increased from 2000 to 2008. Indonesia and Pakistan were the largest contributing countries to emissions in Southeast Asia and South Asia outside India, respectively. Emissions from the road transport sector were increasing in Southeast Asia. The relative contribution of $\mathrm{SO}_{2}$ emissions from Asian Russia was large because of non-ferrous metal production in Ural and Eastern Siberia regions, especially in Norilsk.

The areas of greatest emissions were in China and India, especially in eastern China and the Indo-Gangetic Plain, where there are large populations and vigorous economic and industrial activity. Emissions of $\mathrm{NH}_{3}, \mathrm{CH}_{4}$, and $\mathrm{N}_{2} \mathrm{O}$ were distributed over rural areas dominated by agriculture. High $\mathrm{CH}_{4}$ emissions occurred in Ural, Western Siberia, and Southeast Asia as a result of gas- and oil-related activities. Noteworthy seasonal variations included a winter peak in emissions, such as primary aerosols and CO, especially in northern locations with cold winters. Contributions to these emissions from residential stoves were large. There was also a large summer peak in soil $\mathrm{NO}_{\mathrm{x}}$ emissions, the controlling factors being surface soil temperature and leaf area index.

To improve this bottom-up emission inventory, it is essential to get critical feedback from users of the data, especially researchers who use atmospheric chemistry models including inverse modeling and observation data. In addition, there is a requirement for continuous improvement of basic activity data, country- and region-specific emission factors, and information related to emission regulations. For our next steps, we plan to prepare projections of future emissions based on several scenarios, especially for air quality and climate change studies of the Asian region. We also plan to update historical data and extend the last year of the inventory.

\section{Supplementary material related to this article is available online at http://www.atmos-chem-phys.net/13/ 11019/2013/acp-13-11019-2013-supplement.pdf.}

Acknowledgements. This work was supported by the Global Environment Research Fund of the Ministry of the Environment, Japan (S-7). We appreciate S. Nakatsuka (NTT DATA CCS Corporation), S. Chatani (Toyota Central R \& D Labs., Inc.), and T. Sakurai (Japan NUS Co., Ltd.) for their great help in providing emissions in Japan, from stationary sources, road transport, and navigation, respectively. We acknowledge I. Uno (Kyushu University), K. Yamaji (Japan Agency for Marine Earth Science and Technology), and H. Tian (Beijing Normal University) for valuable comments in updating REAS. We thank Y. Asada (Mitsubishi UFJ Research and Consulting) for her help in collecting activity data. Generic Mapping Tools (GMT) was used for drawing the emission maps (Wessel and Smith, 1998).

Edited by: A. Pozzer

\section{References}

Adhikary, B., Carmichael, G. R., Kulkarni, S., Wei, C., Tang, Y., D’Allura, A., Mena-Carrasco, M., Streets, D. G., Zhang, Q., Pierce, R. B., Al-Saadi, J. A., Emmons, L. K., Pfister, G. G., Avery, M. A., Barrick, J. D., Blake, D. R., Brune, W. H., Cohen, R. C., Dibb, J. E., Fried, A., Heikes, B. G., Huey, L. G., O’Sullivan, D. W., Sachse, G. W., Shetter, R. E., Singh, H. B., Campos, T. L., Cantrell, C. A., Flocke, F. M., Dunlea, E. J., Jimenez, J. L., Weinheimer, A. J., Crounse, J. D., Wennberg, P. O., Schauer, J. J., Stone, E. A., Jaffe, D. A., and Reidmiller, D. R.: A regional scale modeling analysis of aerosol and trace gas distributions over the eastern Pacific during the INTEX-B field campaign, Atmos. Chem. Phys., 10, 2091-2115, doi:10.5194/acp-10-20912010, 2010.

Akimoto, $\mathrm{H}$. and Narita, $\mathrm{H}$.: Distribution of $\mathrm{SO}_{2}, \mathrm{NO}_{\mathrm{x}}$, and $\mathrm{CO}_{2}$ emissions from fuel combustion and industrial activities in Asia with $1^{\circ} \times 1^{\circ}$ resolution, Atmos. Environ., 28, 213-225, 1994.

Akimoto, H., Ohara, T., Kurokawa, J., and Horii, N.: Verification of energy consumption in China during 1996-2003 by using satellite observation data, Atmos. Environ., 40, 7663-7667, 2006.

Bo, Y., Cai, H., and Xie, S. D.: Spatial and temporal variation of historical anthropogenic NMVOCs emission inventories in China, Atmos. Chem. Phys., 8, 7297-7316, doi:10.5194/acp-8-72972008, 2008.

Boden, T. A., Marland, G., and Andres, R. J.: Global, regional, and national fossil-fuel $\mathrm{CO}_{2}$ emissions, Carbon Dioxide Information Analysis Center, Oak Ridge National Laboratory, US Department of Energy, Oak Ridge, Tennessee, USA., doi:10.3334/CDIAC/00001_V2013, available at: http:// cdiac.ornl.gov/trends/emis/overview_2010.html, 2013.

Bond, T. C., Bhardwaj, E., Dong, R., Jogani, R., Jung, S., Roden, C., Streets, D. G., and Trautmann, N. M.: Historical emissions of black and organic carbon aerosol from energy-related combustion, 1850-2000, Global Biogeochem. Cy., 21, GB2018, doi:10.1029/2006GB002840, 2007.

Borken, J., Bei, X., Jiang, Y., and Merétei, T.: Road transportation in China: How big are fuel consumption and pollutant emissions really?, 87th Annual Meeting Transportation Research Board Abstract, Washington, DC, 2008.

Cao, G., Zhang, X., and Zheng, F.: Inventory of black carbon and organic carbon emissions from China, Atmos. Environ., 40, 6516$6527,2006$. 
Chakraborty, N., Mukherjee, I., Santra, A. K., Chowdhury, S., Chakraborty, S., Bhattacharya, S., Mitra, A. P., and Sharma, C.: Measurement of $\mathrm{CO}_{2}, \mathrm{CO}, \mathrm{SO}_{2}$, and $\mathrm{NO}$ emissions from coalbased thermal power plants in India, Atmos. Environ., 42, 10731082, 2008.

CIESIN (Center for International Earth Science Information Network), Columbia University, United Nations Food and Agriculture Programme (FAO), and Centro Internacional de Agricultura Tropical (CIAT): Gridded Population of the World, Version 3 (GPWv3), Population Count Grid, Future Estimates, Palisades, NY, NASA Socioeconomic Data and Applications Center (SEDAC), available at: http://sedac.ciesin.columbia.edu/data/ set/gpw-v3-population-count-future-estimates (last access: 10 November 2013), 2005.

CIESIN (Center for International Earth Science Information Network), Columbia University, International Food Policy Research Institute (IFPRI), The World Bank, and Centro Internacional de Agricultura Tropical (CIAT): Global Rural-Urban Mapping Project, Version 1 (GRUMPv1), Population Count Grid, Palisades, NY, NASA Socioeconomic Data and Applications Center (SEDAC), available at: http://sedac.ciesin.columbia.edu/data/set/ grump-v1-population-count (last access: 10 November 2013), 2011

EC-JRC/PBL (European Commission, Joint Research Center/Netherlands Environmental Assessment Agency), Emission Database for Global Atmospheric Research (EDGAR), release version 4.2, available at: http://edgar.jrc.ec.europa.eu/index.php (last access: 10 November 2013), 2011.

EEA (European Environment Agency): EMEP/EEA air pollutant emission inventory guidebook 2009, EEA Technical report, 9, available at: http://www.eea.europa.eu/publications/ emep-eea-emission-inventory-guidebook-2009 (last access: 10 November 2013), 2009.

FAO (Food and Agriculture Organization of the United Nations): FAOSTAT, The Statistics Division of the FAO, Rome, available at: http://faostat3.fao.org/home/index.html (last access: 10 November 2013), 2011.

Gadi, R., Kulshrestha, U. C., Sarkar, A. K., Garg, S. C., and Parashar, D. C.: Emissions of $\mathrm{SO}_{2}$ and $\mathrm{NO}_{\mathrm{x}}$ from biofuels in India, Tellus, 55B, 787-795, 2003.

Garg, A., Shukla, P. R., and Kapshe, M.: The sectoral trends of multigas emissions inventory of India, Atmos. Environ., 40, 4608-4620, 2006.

Gurjar, B. R., van Aardenne, J. A., Lelieveld, J., and Mohan, M.: Emission estimates and trends (1990-2000) for megacity Delhi and implications, Atmos. Environ., 38, 5663-5681, 2004.

Huang, C., Chen, C. H., Li, L., Cheng, Z., Wang, H. L., Huang, H. Y., Streets, D. G., Wang, Y. J., Zhang, G. F., and Chen, Y. R.: Emission inventory of anthropogenic air pollutants and VOC species in the Yangtze River Delta region, China, Atmos. Chem. Phys., 11, 4105-4120, doi:10.5194/acp-11-4105-2011, 2011.

Huang, X., Song, Y., Li, M., Li, J., Huo, Q., Cai, X., Zhu, T., Hu, M., and Zhang, H.: A high-resolution ammonia emission inventory in China, Global Biogeochem. Cy., 26, GB1030, doi:10.1029/2011GB004161, 2012.

IEA (International Energy Agency): Energy balances of OECD countries and energy balances of non-OECD countries, IEA, Paris, 2011.
IIASA (International Institute for Applied Systems Analysis): RAINS-ASIA CD-ROM Version 7.52, Laxenburg, Austria, 2001.

IIASA: The Greenhouse Gas and Air Pollution Integrations and Synergies (GAINS)-Model available at: http://gains.iiasa.ac.at/ index.php/home-page (last access: 10 November 2013), 2012.

IPCC (Intergovernmental Panel on Climate Change), the National Greenhouse Gas Inventories Programme, Eggleston, H. S., Buendia, L., Miwa, K., Ngara, T., and Tanabe, K.(eds.): 2006 IPCC Guidelines for National Greenhouse Gas Inventories, published by the Institute for Global Environmental Strategies (IGES), Hayama, Japan on behalf of the IPCC, available at: http://www. ipcc-nggip.iges.or.jp/public/2006gl/index.html (last access: 10 November 2013), 2006.

IRF (International Road Federation): World Road Statistics 20062010, International Road Federation, Geneva, 2006-2010.

Jacob, D. J., Crawford, J. H., Kleb, M. M., Connors, V. S., Bendura, R. J., Raper, J. L., Sachse, G. W., Gille, J. C., Emmons, L., and Heald, C. L.: The Transport and Chemical Evolution over the Pacific (TRACE-P) aircraft mission: Design, execution, and first results, J. Geophys. Res., 108, 9000, doi:10.1029/2002JD003276, 2003.

JPEC (Japan Petroleum Energy Center): Emission inventory of road transport in Japan, JPEC Technical Report (in Japanese), JPEC2011AQ-02-06, 136 pp., 2012a.

JPEC: Emission inventory of sources other than road transport in Japan, JPEC Technical Report (in Japanese), JPEC-2011AQ-0207, 288 pp., 2012 b.

JPEC: Speciation profiles of VOC, PM, and $\mathrm{NO}_{\mathrm{x}}$ emissions for atmospheric simulations of $\mathrm{PM}_{2.5}$, JPEC Technical Report (in Japanese), JPEC-2011AQ-02-08, 69 pp., 2012c.

Kato, N. and Akimoto, H.: Anthropogenic emissions of $\mathrm{SO}_{2}$ and $\mathrm{NO}_{\mathrm{x}}$ in Asia: emissions inventories, Atmos. Environ., 26, $2997-$ 3017, 1992.

Klimont, Z., Streets, D. G., Gupta, S., Cofara, J., Lixin, Fu., and Ichikawa, Y.: Anthropogenic emissions of non-methane volatile organic compounds in China, Atmos. Environ., 36, 1309-1322, 2002a.

Klimont, Z., Cofala, J., Bertok, I., Amann, M., Heyes, C., and Gyarfas, F.: Modeling particulate emissions in Europe: A framework to estimate reduction potential and control costs, IIASA, Interim Report IR-02-076, 2002b.

Klimont, Z., Cofala, J., Xing, J., Wei, W., Zhang, C., Wang, S., Kejun, J., Bhandari, P., Mathur, R., Purohit, P., Rafaj, P., Chambers, A., Amann, M., and Hao, J.: Projections of $\mathrm{SO}_{2}, \mathrm{NO}_{\mathrm{x}}$, and carbonaceous aerosols emissions in Asia, Tellus, 61B, 602-617, 2009.

Kupiainen, K. and Klimont, Z.: Primary emissions of submicron and carbonaceous particles in Europe and the potential for their control, IIASA, Interim Report IR-04-079, 2004.

Lee, D. G., Lee, Y.-M., Jang, K.-W., Yoo, C., Kang, K.-H., Lee, J.-H., Jung, S.-W., Park, J.-M., Lee, S.-B., Han, J.-S., Hong, J.H., and Lee, S.-J.: Korean national emissions inventory system and 2007 air pollutant emissions, Asian J. Atmos. Environ., 5, 278-291, 2011.

Lei, Y., Zhang, Q., He, K. B., and Streets, D. G.: Primary anthropogenic aerosol emission trends for China, 1990-2005, Atmos. Chem. Phys., 11, 931-954, doi:10.5194/acp-11-931-2011, 2011a. 
Lei, Y., Zhang, Q., Nielsen, C., and He, K. B.: An inventory of primary air pollutants and $\mathrm{CO}_{2}$ emissions from cement production in China, 1990-2020, Atmos. Environ., 45, 147-154, $2011 \mathrm{~b}$.

Liu, X.-H., Zhang, Y., Cheng, S.-H., Xing, J., Zhang, Q., Streets, D. G., Jang, C., Wang, W.-X., and Hao, J.-M.: Understanding of regional air pollution over China using CMAQ, part I performance evaluation and seasonal variation, Atmos. Environ., 44, 2415-2426, 2010.

Lu, Z., Streets, D. G., Zhang, Q., Wang, S., Carmichael, G. R., Cheng, Y. F., Wei, C., Chin, M., Diehl, T., and Tan, Q.: Sulfur dioxide emissions in China and sulfur trends in East Asia since 2000, Atmos. Chem. Phys., 10, 6311-6331, doi:10.5194/acp-106311-2010, 2010.

Lu, Z., Zhang, Q., and Streets, D. G.: Sulfur dioxide and primary carbonaceous aerosol emissions in China and India, 1996-2010, Atmos. Chem. Phys., 11, 9839-9864, doi:10.5194/acp-11-98392011, 2011.

Mastepanov, A. M.: Russian energy strategy of 21 century (in Japanese), Tozai Boeki Tshusinsha, 603 pp., 2001.

MOEJ (Ministry of Environment of Japan): Report on Volatile Organic Compound (VOC) Emission Inventory Compiled [in Japanese], available at: http://www.env.go.jp/air/osen/voc/ inventory.html (last access: 10 November 2013), 2009.

Nagashima, T., Ohara, T., Sudo, K., and Akimoto, H.: The relative importance of various source regions on East Asian surface ozone, Atmos. Chem. Phys., 10, 11305-11322, doi:10.5194/acp10-11305-2010, 2010

National Bureau of Statistics: China statistical yearbook (20002008), China Statistics Press, Beijing, 2001-2009.

National Bureau of Statistics: China energy statistics yearbook (2000-2008), China Statistics Press, Beijing, 2004-2009.

Ohara, T., Akimoto, H., Kurokawa, J., Horii, N., Yamaji, K., Yan, X., and Hayasaka, T.: An Asian emission inventory of anthropogenic emission sources for the period 1980-2020, Atmos. Chem. Phys., 7, 4419-4444, doi:10.5194/acp-7-4419-2007, 2007.

Onogi, K., Tsutusi, J., Koide, H., Sakamoto, M., Kobayashi, S., Hatsushika, H., Matsumoto, T., Yamazaki, N., Kamahori, H., Takahashi, K., Kadokura, S., Wada, K., Kato, K., Oyama, R., Ose, T., Mannoji, N., and Taira, R.: The JRA-25 reanalysis, J. Meteor, Soc. Japan, 85, 369-432, 2007.

OPRF (Ocean Policy Research Foundation (Ship and Ocean Foundation)): Report for comprehensive study for environmental impact lead by the establishment of emission control area in Japan (in Japanese), ISBN978-4-88404-282-0, 524 pp., 2012.

Platts: The UDI World Electric Power Plants Database, CD-ROM data, Platts, A division of the McGraw-Hill Companies, New York, 2009.

Qin, Y. and Xie, S. D.: Spatial and temporal variation of anthropogenic black carbon emissions in China for the period 19802009, Atmos. Chem. Phys., 12, 4825-4841, doi:10.5194/acp-124825-2012, 2012.

Reddy, M. S. and Venkataraman, C.: Inventory of aerosol and sulphur dioxide emissions from India: I-Fossil fuel combustion, Atmos. Environ., 36, 677-697, 2002a.

Reddy, M. S. and Venkataraman, C.: Inventory of aerosol and sulphur dioxide emissions from India. Part II - biomass combustion, Atmos. Environ., 36, 699-712, 2002b.
Ryaboshapko, A. G., Brukhanov, P. A., Gromov, S. A., Proshina, Y. V., and Afinogenova, O. G.: Anthropogenic emissions of oxidized sulfur and nitrogen into the atmosphere of the Former Soviet Union in 1985 and 1990, Report CM-89, Department of Meteorology, Stockholm University, International Meteorological Institute in Stockholm, 1996.

Shindell, D., Kuylenstierna, J. C. I., Vignati, E., van Dingenen, R., Amann, M., Klimont, Z., Anenberg, S. C., Muller, N., JanssensMaenhout, G., Raes, F., Schwartz, J., Faluvegi, G., Pozzoli, L., Kupiainen, K., Höglund-Isaksson, L., Emberson, L., Streets, D., Ramanathan, V., Hicks, K., Oanh, N. T. K., Milly, G., Williams, M., Demkine, V., and Fowler, D.: Simultaneously Mitigating Near-Term Climate Change and Improving Human Health and Food Security, Science, 335, 183-189, 2012.

Singh, H. B., Brune, W. H., Crawford, J. H., Flocke, F. and Jacob, D. J.: Chemistry and transport of pollution over the Gulf of Mexico and the Pacific: Spring 2006 INTEX-B campaign overview and first results, Atmos. Chem. Phys., 9, 2301-2318, doi:10.5194/acp-9-2301-2009, 2009.

Smith, S. J., van Aardenne, J., Klimont, Z., Andres, R. J., Volke, A., and Arias, S. D.: Anthropogenic sulfur dioxide emissions: 1850 2005, Atmos. Chem. Phys., 11, 1101-1116, doi:10.5194/acp-111101-2011, 2011

Streets, D. G. and Waldhoff, S. T.: Biofuel use in Asia and acidifying emissions, Energy, 23, 1029-1042, 1998.

Streets, D. G., Bond, T. C., Carmichael, G. R., Fernandes, S. D., Fu, Q., He, D., Klimont, Z., Nelson, S. M., Tsai, N. Y., Wang, M. Q., Woo, J.-H., and Yarber, K. F.: An inventory of gaseous and primary aerosol emissions in Asia in the year 2000, J. Geophys. Res., 108, 8809, doi:10.1029/2002JD003093, 2003 a.

Streets, D. G., Yarber, K. F., Woo, J.-H., and Carmichael, G. R.: Biomass burning in Asia: Annual and seasonal estimates and atmospheric emissions, Global Biogeochem. Cy., 17, 1099, doi:10.1029/2003GB002040, 2003b.

Streets, D. G., Zhang, Q., Wang, L., He, K. B., Hao, J., Wu, Y., Tang, Y., and Carmichael, G. R.: Revisiting China's CO emissions after the Transport and Chemical Evolution over the Pacific (TRACE-P) mission: Synthesis of inventories, atmospheric modeling, and observations, J. Geophys. Res., 111, D14306, doi:10.1029/2006JD007118, 2006.

UN (United Nations): United Nations Energy Statistics Database, United Nations Statistics Division, New York, available at: http: //data.un.org/Default.aspx, 2011.

UNEP (United Nations Environment Programme): Integrated Assessment of Black Carbon and Tropospheric Ozone, ISBN978-92-807-3142-2, 38pp, available at: http://www.unep. org/publications/contents/pub_details_search.asp?ID=6201, 2011.

US EPA (United States Environmental Protection Agency): Compilation of air pollutant emission factors (AP-42) Volume 1: Stationary point and area sources, US Environmental Protection Agency, Research Triangle Park, NC, 1995.

USGS (United States Geological Survey): Minerals Yearbook, Volume III, Area Reports: International, available at: http://minerals. usgs.gov/minerals/pubs/myb.html, 2004-2008.

Venkataraman, C., Habib, G., Eiguren-Fernandez, A., Miguel, A. H., and Fiedlander, S. K.: Residential biofuels in South Asia: Carbonaceous aerosols emissions and climate impacts, Science, 307, 1454-1456, 2005. 
Wei, W., Wang, S., Chatani, S., Klimont, Z., Cofala, J., and Hao, J.: Emission and speciation of non-methane volatile organic compounds from anthropogenic sources in China, Atmos. Environ., 42, 4976-4988, 2008.

Wessel, P. and Smith, W. H. F.: New, improved version of Generic Mapping Tools released, EOS Trans. Amer. Geophys. Union., 79, 579, doi:10.1029/98EO00426, 1998.

Wheeler, D. and Ummel, K.: Calculating CARMA: Global estimation of $\mathrm{CO}_{2}$ emissions from the power sector, Center for Global Development, Working Paper 145, 2008.

World Steel Association: Steel Statistical Yearbook 2010, World Steel Association, Brussels, available at: http://www.worldsteel. org/statistics/statistics-archive/yearbook-archive.html, 2010.

Wu, Y., Wang, R., Zhou, Y., Lin, B., Fu, L., He, K. B., and Hao, J.: On-road vehicle emission control in Beijing: Past, present, and future, Environ., Sci., Technol., 45, 147-153, 2011.

Yamaji, K., Ohara, T., and Akimoto, H.: A country-specific highresolution emission inventory for methane from livestock in Asia in 2000, Atmos. Environ., 37, 4393-4406, 2003.

Yamaji, K., Ohara, T., and Akimoto, H.: Regional-specific emission inventory for $\mathrm{NH}_{3}, \mathrm{~N}_{2} \mathrm{O}$, and $\mathrm{CH}_{4}$ via animal farming in South, Southeast, and East Asia, Atmos. Environ., 38, 7111-7121, 2004.

Yan, X., Cai, Z., Ohara, T., and Akimoto, H.: Methane emission from rice fields in mainland China: Amount and seasonal and spatial distribution, J. Geophys. Res., 108, 4505, doi:10.1029/2002JD003182, 2003a.

Yan, X., Ohara, T., and Akimoto, H.: Development of regionspecific emission factors and estimation of methane emission from rice field in East, Southeast and South Asian countries, Global Change Biol., 9, 237-254, 2003 b.

Yan, X., Akimoto, H., and Ohara, T.: Estimation of nitrous oxide, nitric oxide, and ammonia emissions from croplands in East, Southeast, and South Asia, Global Change Biol., 9, 1080-1096, 2003c.

Yan, X., Ohara, T., and Akimoto, H.: Statistical modeling of global soil $\mathrm{NO}_{\mathrm{x}}$ emissions, Global Biogeochem. Cy., 19, GB3109, doi:10.1029/2004GB002276, 2005.
Yan, X., Ohara, T., and Akimoto, H.: Bottom-up estimate of biomass burning in mainland China, Atmos. Environ., 40, 52625273, 2006.

Zhang, Q., Streets, D. G., He, K. B., Wang, Y., Richter, A., Burrows, J. P., Uno, I., Jang, C. J., Chen, D., Yao, Z., and Lei, Y.: $\mathrm{NO}_{\mathrm{x}}$ emission trends for China, 1995-2004: The view from the ground and the view from space, J. Geophys. Res., 112, D22306, doi:10.1029/2007JD008684, 2007.

Zhang, Q., Streets, D. G., Carmichael, G. R., He, K. B., Huo, H., Kannari, A., Klimont, Z., Park, I. S., Reddy, S., Fu, J. S., Chen, D., Duan, L., Lei, Y., Wang, L. T., and Yao, Z. L.: Asian emissions in 2006 for the NASA INTEX-B mission, Atmos. Chem. Phys., 9, 5131-5153, doi:10.5194/acp-9-5131-2009, 2009a.

Zhang, Q., Streets, D. G., and He, K. B.: Satellite observations of recent power plant construction in Inner Mongolia, China, Geophys. Res. Lett., 36, L15809, doi:10.1029/2009GL038984, $2009 b$.

Zhao, Y., Wang, S., Duan, L., Lei, Y., Cao, P., and Hao, J.: Primary air pollutant emissions of coal-fired power plants in China: Current status and future prediction, Atmos. Environ., 42, 84428452, 2008.

Zhao, Y., Wang, S., Nielsen, C. P., Li, X., and Hao, J.: Establishment of a database of emission factors for atmospheric pollutants from Chinese coal-fired power plants, Atmos. Environ., 44, 1515-1523, 2010.

Zhao, Y., Nielsen, C. P., Lei, Y., McElroy, M. B., and Hao, J.: Quantifying the uncertainties of a bottom-up emission inventory of anthropogenic atmospheric pollutants in China, Atmos. Chem. Phys., 11, 2295-2308, doi:10.5194/acp-11-2295-2011, 2011.

Zhao, B., Wang, P., Ma, J. Z., Zhu, S., Pozzer, A., and Li, W.: A high-resolution emission inventory of primary pollutants for the Hubei region, China, Atmos. Chem. Phys., 12, 481-501, doi:10.5194/acp-12-481-2012, 2012.

Zheng, J., Zhang, L., Che, W., Zheng, Z., and Yin, S.: A high resolved temporal and spatial air pollutant emission inventory for the Perl River Delta region, China and its uncertainty assessment, Atmos. Environ., 43, 5112-5122, 2009. 